University of Louisville

ThinkIR: The University of Louisville's Institutional Repository

8-2005

\title{
The process of the enlargement of the Russian regions : economic balancing or landmark of "Kremlinization"?
}

Igor Yurievich Danchenko

University of Louisville

Follow this and additional works at: https://ir.library.louisville.edu/etd

\section{Recommended Citation}

Danchenko, Igor Yurievich, "The process of the enlargement of the Russian regions : economic balancing or landmark of "Kremlinization"?" (2005). Electronic Theses and Dissertations. Paper 310.

https://doi.org/10.18297/etd/310

This Master's Thesis is brought to you for free and open access by ThinkIR: The University of Louisville's Institutional Repository. It has been accepted for inclusion in Electronic Theses and Dissertations by an authorized administrator of ThinkIR: The University of Louisville's Institutional Repository. This title appears here courtesy of the author, who has retained all other copyrights. For more information, please contact thinkir@louisville.edu. 


\title{
THE PROCESS OF THE ENLARGEMENT OF THE RUSSIAN REGIONS: ECONOMIC BALANCING OR LANDMARK OF "KREMLINIZATION"?
}

\section{By}

Igor Yurievich Danchenko

B.A., Perm' State University, Russia, 2000

\author{
A Thesis \\ Submitted to the Faculty of the \\ Graduate School of the University of Louisville \\ in Partial Fulfillment of the Requirements \\ for the Degree of
}

Master of Arts

Department of Political Science

University of Louisville,

Louisville, KY

August 2005 
Copyright 2005 by Igor Y. Danchenko

All Rights Reserved 
THE PROCESS OF THE ENLARGEMENT OF THE RUSSIAN REGIONS:

ECONOMIC BALANCING OR LANDMARK OF “KREMLINIZATION”?

By Igor Y. Danchenko

B.A., Perm' State University, Perm', Russia, 2000

A Thesis Approved on

July 19, 2005

by the following Thesis Committee:

Thesis Director 


\section{ACKNOWLEDGEMENTS}

I would like to thank Professor Charles E. Ziegler, my Thesis Director and my mentor at the Political Science Department, for his guidance on this project, and for his continuous support throughout my study at the University of Louisville. I would like to thank my Family for making me what I am today, and especially my Liza for her love, and for her help in brainstorming the data for this thesis. I would also like to express my gratitude to Professors Fiona Hill and Clifford G. Gaddy for their constructive suggestions and inspiration on this and other projects. Finally, I would like to thank the other members of my Thesis Committee - Professors Bruce Adams and Ronald K. Vogel, and my Professors at the Political Science Department of the University of Louisville - Julie M. Bunck, Tricia Gray, Roger Payne, Laurie Rhodebeck, and Paul Weber. 


\begin{abstract}
THE PROCESS OF THE ENLARGEMENT OF THE RUSSIAN REGIONS: ECONOMIC BALANCING OR LANDMARK OF "KREMLINIZATION"?

\author{
Igor Y. Danchenko
}

August 5, 2005

Every state, regardless of its size, faces a problem of spatial organization and distribution of its power over territory, particularly in times of the formation of its statehood and the establishment of the system of governance. The territorialadministrative reform in modern Russia has taken an unprecedented scale over the last five years. Recollecting the experiences of the imperial Russia and the Soviet Union, Putin's reforms aim at elimination of a whole tier of Russia's federative units - autonomous okrugs - by merging them with adjacent regions. Arguably, the enlargement of Russian regions and the reduction of their number from the current eighty-nine would be socio-economically beneficial for regions, and would make Russia a more symmetrical, and thus a more governable federation.

There appears to be no single clear rationale for the enlargement. Based on three case studies, I assess the political, economic, and demographic arguments for the regional enlargement in Russia, and draw conclusions whether the process would, as the current Russian government contends, indeed benefit the regions, or would it 
benefit the state, both the regions and the state, or neither. Assessing the regional enlargement in a qualitative and quantitative analysis, I characterize the process in terms of its top-down or bottom-up qualities, its implications for the regions, and its contribution to the symmetry of Russian federalism. Russia is a state in the making, and the analysis of regional enlargement is one of the linchpins of its development. 


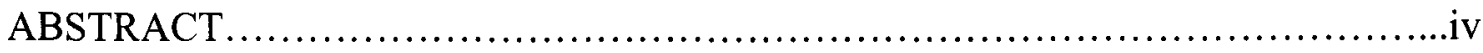

LIST OF TABLES ................................................................

LIST OF CHARTS, SCHEMES, AND MAPS ......................................

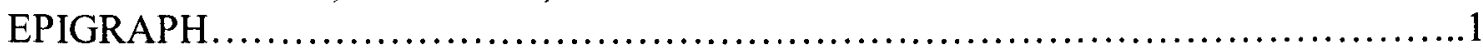

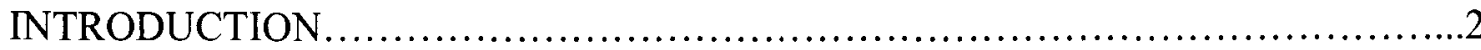

CHAPTER I. CONTEXT OF THE ENLARGEMENT OF RUSSIAN REGIONS.........4

Research Questions and Hypothesis.........................................4

Thesis Structure ........................................................ 10

Literature Review....................................................... 12

Historical Background.................................................23

CHAPTER II. DEMOGRAPHICS OF REGIONAL ENLARGEMENT ................45

Population-to-Landmass Ratio...........................................45

Demographic Situation since the Breakup of the USSR ......................47

Mergers of Regions as Mergers of Cities...................................52

Dilution of Aboriginal Vote......................................................56

Demographic Factor in the Enlargement of Regions..........................60

CHAPTER III. POLITICS OF REGIONAL ENLARGEMENT .......................65

Permskii Krai as a Pilot Project of Regional Enlargement.....................67

Regional Enlargement in Irkutsk and Tyumen' Matryoshkas.....................78 
Political Factor in the Enlargement of Regions................................86

CHAPTER IV. ECONOMICS OF REGIONAL ENLARGEMENT....................89

Economic Asymmetry of Russian Regions...................................90

Constitutional Provisions for Economy ...................................93

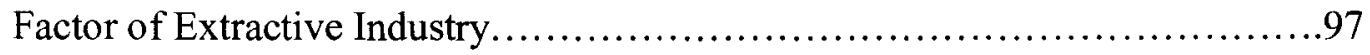

Diversification of Economy and Enhancement of Connectivity of Russia.......106

Trends of Fiscal Federalism............................................. 125

Economic Factor in the Enlargement of Regions.............................133

SUMMARY AND CONCLUSIONS ............................................136

Demographic, Political, and Economic Aspects of Regional Enlargement.......136

Conclusions......................................................................

Security Dilemma of Reunification or Disintegration.......................148

Implications for Future Studies............................................152

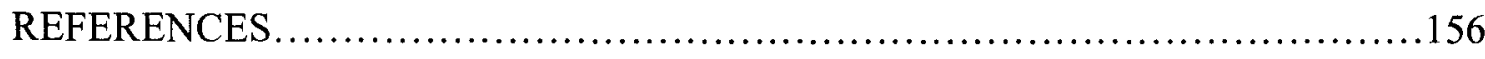

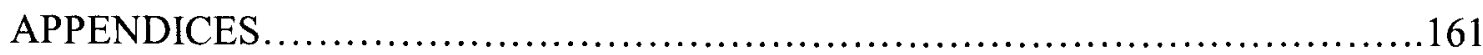

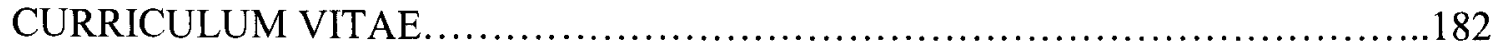




\section{LIST OF TABLES}

1. Dynamics of Russian Federal Division..........................................175

2. General Political and Administrative Information on the Studied Regions...........176

3. Numbers of Ethnic Russians and Other Ethnic Groups in Studied Regions...........177

3-A. Proportion of Ethnic Russians and Other Ethnic Groups in Studied Regions.......178

4. Representation in Legislature in Relation to Landmass and Population of Regions...179

5. Mergers of Regions as Mergers of Regional Capital Cities.........................180

6. Major Enterprises with Significant Presence in the Region and Share of Revenues from Extractive Industries in Consolidated Budgets....................181

7. Basic Indicators of Environmental Protection by Regions of Russia.................111

8. Donor Regions and Recipient Regions in 1995-1999.............................127

9. Typology of Regions by Volume of Balance (by financial aid) in 1999 ..............128

10. Economic Indicators of the Studied Regions and Their Possible Changes after Proposed Mergers. 


\section{LIST OF CHARTS, SCHEMES, AND MAPS}

1. Appendix 1, Note on Transliteration and Terminology.........................161

2. Appendix 2, Abbreviations and Acronyms..................................162

3. Appendix 3, Forms of Russian Regions...................................163

4. Appendix 4, Article 66 of the Russian Constitution...........................164

5. Chart 1, Leading Regions by Volume of Investments per 1 Official, 2004........92

6. Scheme 1, Federal Symmetry in a State..................................165

7. Scheme 2, Federation as a Dynamic Organizational Structure of States..........166

8. Scheme 3, Dynamics of Russian Federalism: 1990-2005_......................167

9. Scheme 4, Ratio of the Direct and Reverse Flows between Federal Budget and Siberian Federal District, January-September 2004...............168

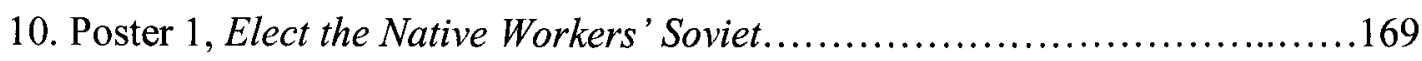

11. Map 1, Russia's Administrative Divisions................................. 170

12. Map 2, Map of Autonomous Areas in Russia...................................171

13. Map 2-A, Russia's Ethnic Republics...................................172

14. Map 3, Federal Districts of the Russian Federation............................173

15. Map 4, Distribution of Russian Population....................................174 
EPIGRAPH

Участок - великая вещь!

Это - место свиданья

Меня и государства.

Государство напоминает,

Что оно всё ещё существует!

A plot of land is a great thing!

A place where I date

The state.

The state reminds

That it still exists! '

Velimir Khlebnikov, Early 1922

${ }^{1}$ Poem in Russian available online at http//lib.ru/POEZIQ/HLEBNIKOW/long/stih.htm English translation of the epigraph by Igor Y. Danchenko 


\section{INTRODUCTION}

Sound state power structure plays a crucial role in the state's ability to execute the supreme authority of law and constitutional order, to effectively implement the decisions of governments and citizens, and to maintain sovereignty. Administrativeterritorial division is an essential element of both unitary and federative states. Democratic states, and particularly large democratic and multiethnic states, tend to prefer a federative system that arguably has the most capacity to serve the interests and needs of the people best. Principles of federalism, usually set up in constitutions, include the principle of delegation of authority to a sub-state regional unit (devolution), which is important for optimization of governing large multiethnic states and preserving their territorial integrity. Comparative landmass and population size, ethnic composition, level of economic development, degree of autonomy, and many other characteristics of units in a federative state constitute the relationships between the state and its units and among the units. These characteristics and relationships along with the overall political, social, and economic climate in federations provide for their symmetry or asymmetry.

All federations attempt to strike a balance in their structure and maintain a degree of symmetry. Symmetrical federations are considered most stable. Therefore, federative states are often compelled to reform their territorial federative systems to 
bring their units to the most harmonious possible form. The processes of such structural reforms are often accompanied by constitutional amendments. Fifteen years after the breakup of the USSR, the Russian Federation is reconsidering its federative structure, as its current territorial division and the nature of federal-regional relations are put to the test. This paper focuses on the unraveling phenomenon of the enlargement of Russian regions with a focus on the reasons underlying this process. 


\section{CHAPTER I. CONTEXT OF THE ENLARGEMENT OF RUSSIAN REGIONS}

\section{RESEARCH QUESTION AND HYPOTHESIS}

I suggest that the enlargement of the Russian regions can be rationalized as a continuous trend of centralization (Kremlinization) of Russia by, first, making the federation more symmetrical and, second, more center-oriented (monocentric) - up to a point of establishment of a unitary state. Can the enlargement of regions be better explained through Russia's federal policies of centralization and making Russian federalism more symmetrical, or through the notion of regional economic and political development? This hypothesis is put to a test in studies of enlargement (merger) in three regions.

There exists a common misperception of Russia as a unitary state and as a given unit of analysis. It is an atavism from the Cold War era, when Soviet federative structure was a nominal mask for the top-down one party control system. The first article of the 1993 Russian Constitution declares the terms Russia and the Russian Federation equal. $^{2}$ Its federative status is often ignored. In fact, "Russia" is a term of convenience, which describes a complex evolving federal system in the Russian Federation.

\footnotetext{
${ }^{2}$ The Constitution of the Russian Federation, December 12, 1993, Article 1-2. Online at http:/kremlin.ru/eng/articles/ConstEngl.shtml
} 
The second public misperception of Russia as a state is the notion of its lasting transition. At present, in light of the allegedly increasingly authoritarian presidential rule of Vladimir Putin, this transition is viewed as that from a democratic state to an authoritarian, partially democratic, or other kind of "hybrid" state. However transition usually implies a starting point, which Russia, as a state, lacks. It is just one of the fifteen constituencies of the USSR, the country that ceased to exist in 1991. Throughout the centuries of statehood in Eurasia, Russia has never assumed its present form, nor has it ever been a democracy or a federation, although some unsuccessful attempts had been made. It only nominally resembles the Russian Soviet Federative Socialist Republic (RSFSR) in its internal and external borders (see Map 1, p. 170). In this respect, I argue that Russia is rather a state under construction or at least reconstruction. Throughout the 1990s, Russia sustained an image and reputation of a "smaller version" of the USSR, in part due to the inertia of the seventy-year communist rule, and in part to Boris Yeltsin's belief in the state's invincible and perpetual mightiness despite economic hardship and challenge of separatism. After succeeding Yeltsin as president, Vladimir Putin publicly admitted the fact that Russia was no longer "the USSR," but a much weaker country. ${ }^{3}$ Indeed, Russia is a different state, a new state, and in many respects a twenty first century experiment, much like the USSR had been in the twentieth.

\footnotetext{
3 "Putin: Edinstvo Strany - Glavnoe Uslovie Protivodeistviya Terroriszmu," (Unity of the State is the Main Condition to Fight Terrorism), Vesti, September 13, 2004, online at www.rtr-vesti.ru and Press Conference by President Vladimir Putin, Moscow, December 23, 2004, Transcript online at www.kremlin.ru/eng/text/speeches/2004/12/23/1806 type82915 81700.shtml, at p. 12-13. Even as Prime Minister in 1999 , Putin commented that Russia had been in the middle of its hardest historical perios.
} 
Considering the above-outlined two misconceptions, this paper attempts to avoid them. First of all, it studies the Russian Federation, rather than Russia, which implies that it is not a unitary, but a federative (although some would partially disagree) state in the process of construction. In particular, it undertakes three case studies of the proposed attempts to merge subjects of the Russian Federation.

The Russian Constitution distinguishes six types of regions: republics (21), krais (6), oblasts (49), cities with federal status (2), autonomous oblast', and autonomous okrugs (10) - all of which are equal subjects of the federation. ${ }^{4}$ The enlargement of Russian regions is characterized by simplification of the Russian federative construct through elimination of some of the regions by merger with other regions. As of August 2005, this simplification has tended to exclusively touch upon the so-called matryoshka regions - the regions of double status. ${ }^{5}$ They are typically comprised of oblasts or krais loosely affiliated with autonomous okrugs located within them (see Map 2, p. 171). Created during Stalin's rule in the 1920s-40s, the latter had been fully incorporated in the territories of the respective oblasts and krais prior to the independence of Russia in 1991. The 1993 Russian Constitution pronounced them independent regions within the Federation. Paradoxically, the okrugs also remain the component parts of larger regions. In addition to mergers of autonomous okrugs, I will review a number of proposed "regional-enlargementthrough-merger" schemes for Russia in the next section.

\footnotetext{
${ }^{4}$ Constitution of the Russian Federation, Article 65-1.

${ }^{5}$ Originally suggested by Bremmer in Ian Bremmer, Reassessing Soviet Nationalities Theories, Cambridge University Press, 1992, recent literature on Russian federalism has adopted the term "matryoshka" to describe these complex federative formations. Matryoshka is a reference to a set of Russian handicraft - a set of wooden dolls. Hollow on the inside, they can be assembled into one large doll by putting smaller ones inside the larger.
} 
By deductively analyzing the current situation in three regions and attempting to rationalize their enlargement, I intend to find explanations for the processes of enlargement. To do so, I undertake three case studies described in the Thesis Structure in more detail. In this section, I propose the hypothesis and explain the title of the paper.

Some definition of terms is in order here. Economic Balancing refers to the degree of balance among the Russian regions in terms of their populations, economies, and the overall level of harmonious (symmetrical) socio-economic development. It is widely suggested that the economic balancing of regions by merging the very poor with the very rich is a process that could benefit all parts in the enlarged region as well as bring more equilibrium into the federal system. ${ }^{6}$

Kremlinization is the term of convenience that I have coined to describe the on-going process of Putin's reforms, which is reviewed in detail in the next chapter. The term emphasizes strengthening of the federal tier of government, and particularly of its executive branch, the Presidency, and Presidential Administration.

As previously emphasized, Russia is a federation. In 1990s, during Yeltsin's years in office, scholars of federalism and Russian federalism have characterized it as

\footnotetext{
${ }^{6}$ See Maria Kravtsova, "Genotsid Matryoshek" (Genocide of the Matryoshki), Expert, \# 12, March 29, 2004, p. 69-72.
} 
a relatively weak, loosely centralized, and asymmetrical state ${ }^{7}$. As Putin's reforms progress, this perception seems to be changing: Russia is perceived as a stronger and a much more centralized state. Despite its centralization, Russia still remains a very asymmetrical federation of $89(86)^{8}$ constituencies.

There are several possible interpretations to my study in regional enlargements. If regional enlargement lacks rationale from the regional standpoint, it may possibly be interpreted as a part of Putin's campaign to strengthen the executive branch through the decrease of the number of federal units, and the simplification of the federative construct. If it were indeed so, I would argue that the enlargement of regions can be characterized as a top-down process, and interpreted as the continuation of the Kremlinization of Russia. The top-down character of this process implies that it is conceived and undertaken at the initiative of federal-level political elites, primarily the President and his administration. However, if I find sufficient evidence that the regional mergers would have a strong positive impact on social and economic development of all parts of the enlarged regions without significant interference from the center, it could be concluded that the enlargement of regions is a bottom-up process. The bottom-up character of the process implies that is undertaken at the initiative of regional and local political elites, primarily regional governors and mayors of large cities. This research may also produce mixed results, which could be interpreted in a number of ways. For example, if I find sufficient

\footnotetext{
${ }^{7}$ See, for example, Daniel R. Kempton and Terry D. Clark (Eds.), Unity or Separation: Center-Periphery Relations in the Former Soviet Union, 2002 and Blair A. Ruble, Jodi Koehn, and Nancy E. Popson (Eds.), Fragmented Space in the Russian Federation, Washington, D.C., Woodrow Wilson Center Press; Baltimore, John Hopkins University Press, 2001.

${ }^{8} 88$ upon the formation of Permskii Krai, and 86 upon the unification of the Krasnoyarskii Krai.
} 
evidence to support both the bottom-up and the top-down scenarios, then the enlargement could be interpreted from the standpoint of efficient governance as a rational process with a long-term goal of formation of a more symmetrical federation by utilizing the existing leverage that Putin's government has gained for a variety of reasons that are not subject of this research. At the same time, I don't rule out a possibility of reaching yet a different conclusion about the nature and goals of the process of regional enlargement.

To summarize, the research question could be broken down into several questions and formulated as follows. First, is the rationale for the enlargement of regions largely political, largely economic, both, or neither? Second, is the enlargement of the Russian regions a state-orchestrated process to reform and strengthen the federal government and, possibly, Russia's economy, or is this process undertaken at the initiative of the respective regions and is it grounded strictly in regional, as opposed to federal, urgent economic necessity? In sum, is the enlargement of regions a top-down or a bottom-up calculated process, a combination of both, or can it not be described in these terms? Finally, does the enlargement lead to formation and consolidation of a more symmetrical, or less symmetrical (asymmetrical) federative state in Russia? If the relations between the federal power and the power of the constituencies would become more asymmetrical and skewed towards the federal government, then the enlargement of regions may signify a temporary or a permanent shift from a federative system to a unitary state (Kremlinization). If the asymmetry would be skewed towards the constituencies, it 
may signify the continuation of the existence of Russia as a loose federation with relatively weak central authority. Also, if the enlargement of regions further enhances political and socio-economic disparity among regions, it would create a more asymmetrical federation. If, on the opposite, enlargement would facilitate the harmonization of regions - greater equality in their political status and by socioeconomic characteristics, the enlargement would result in more symmetry in the RF (see Scheme 1, p. 165)

\section{THESIS STRUCTURE}

The thesis structure is as follows. First, the historic background for the researched topic is set up. It is then followed by a review of relevant literature on federalism and regionalism in general and on the Soviet and Russian federalism in particular. Then I discuss the schemes of regional enlargement and federative construct of Russia proposed by politicians and scholars. The next part of the paper is its substantive research part, conducted in the form of case studies, both qualitative and quantitative in nature. I assess the enlargement of Russian regions using statistical data on population, ethnic composition, gross regional product (GRP), budgetary balance and other data from a variety of sources, including GosKomStat, the official Russian statistical department, and based on empirical data from a variety of sources including scholarly books, magazines, and newspapers, as well as multiple online sources. I have chosen three cases to illustrate the on-going enlargement policies. I study the mergers of Perm' Oblast' and Komi-Permyatskii Autonomous Okrug (KPAO), Tyumen' Oblast' and Khanty-Mansiiskii (KhMAO) and Yamalo- 
Nenetskii (YaNAO) Autonomous Okrugs, and Irkutsk Oblast' and Ust'-Ordynskii Byruatskii Autonomous Okrug (U-OBAO). Some tables also include data from the City of Moscow, the Republic of Tatarstan, and the Republic of Chechnya, as well as indicators for Russia's average and Russia's total for comparatively positioning the studied regions in the Russian Federation (See Map 2-A, p. 172).

In separate chapters, I study the demographic, political, and economic aspects of regions where merger has been successfully negotiated and where merger is a focus of regional debate. In the section on the political dimension I examine the role of the federal center in the enlargement process, the political situation in the regions, and the possible outcomes for regions as new units of the Federation in case of their merger and the federal symmetry. The section on economic dimension tests the validity of the claims of both federal and regional authorities that the enlargement is a process expected to facilitate economic growth and higher living standards, and enhance the balance in Russia's budgetary federalism. Finally, I singled out a demographic dimension in a separate section to assess the role that the skewed distribution of the population and the gross population decrease possibly play in the rationalization of the enlargement. Despite the rather small sample, the chosen regions are geographically and socio-economically diverse, and mergers have been proposed and partially implemented in all of them. 
I strongly believe that modern Russia "ought to be studied in the process of its formation, rather than a static construct." 9 The study of regional mergers, their dynamics, and end results grants a unique opportunity to assess the current policies and trends of this formation. The research contributes to the analysis and understanding of Russia's domestic policy during Putin's presidency through the prism of the changing nature of Russia's federalism.

In the end I assess underlying reasons for the mergers and their possible outcomes for the respective regions and for the state. Based on the studies in enlargement of the Russian regions, I evaluate the degree of symmetry of Russian federalism and the impact that the enlargement of regions may have on the system of governance. Since the enlargement is an ongoing process, I do not draw definitive conclusions. It is unclear whether and how the enlargement would continue. However, I outline the possible trajectories of development of Russian federalism and its rationale with respect to enlargement. Finally, I briefly discuss the implications of my paper for future studies.

\section{LITERATURE REVIEW}

There is a variety of ways to systematize states. There are two major distinctions in their types. Regime-wise states can be democratic and non-democratic, with subcategories in both. In terms of territory and the distribution of power and

\footnotetext{
${ }^{9}$ Pauline Jones Luong, "Reconceptualizing the State: Lessons from Post-Communism," Politics and Society, Vol. 30, No. 4, December 2002, p. 532.
} 
control functions, they are divided into unitary states and federations ${ }^{10}$, confederations being a separate type or a subcategory of federations, as a part of evolutions of federations. ${ }^{11}$

Federations undergo certain stages in their development. At some point in history all of them evolve to and from unitary states and confederations (see Scheme 2, p. 166). This inherent dynamism of their evolution can be attributed to their structure. Dividing sovereignty between federal and regional levels of government, federations are forged as compromise forms of political organization. Originally developed in the United States to implement the Jeffersonian idea of limited government through preservation of a degree of regional autonomy, federal systems are routinely adopted by many unitary states with certain characteristics that can potentially destabilize them. Some states include historically independent constituencies, while others are homes to culturally and ethnically different communities. Federalism is the most democratic form of political organization capable of delivering the balance between independence of units and independence of the state as a whole. This balance is delivered in a dynamic process - federations need to constantly adjust their federal arrangements according to various internal and external conditions. Federations are prone to disintegration or centralization if they fail to make the timely necessary adjustments. Both disintegration and centralization are evolutionary stages of federal states.

\footnotetext{
${ }^{10}$ Non-democratic (authoritarian) states cannot be genuinely federated. Their federative division is usually the means for administrative central control. Federative division may be used to mask the centralized nature of the state system. Primary example of such state was the USSR.

${ }^{11}$ Carl J. Friedrick, Constitutional Government and Democracy, Boston, Ginn and Company, 1950, p. 151.
} 
Most federations, like the US, Canada, and Spain, formed historically over long periods of time, and their adjustment mechanisms are well-developed. The slow dynamics of their development can be traced centuries back. Other federations, like the USSR and Yugoslavia (SFRYu), "skipped" many developmental stages. Their federative structures were imposed by central governments in very short time frames. Over the last decade of the twentieth century these "imposed" federations demonstrated unexpectedly great dynamic potential. USSR and SFRYu disintegrated with the same pace they had been created, and started forming new nation-states at an even greater pace.

Russia, itself a former federal unit, demonstrates a new pattern of the dynamic potential of federations - the potential of speedy cyclical change. In little over a decade since its emergence from the ruins of the Soviet state, it has promptly adopted a new federal system, and almost simultaneously embarked on a path of recentralization in order to develop a strong nation-state (See Scheme 3, p. 167). This seemingly paradoxical vector of development, and the speed with which Russia follows it, raises a number of questions about the phenomenon of Russian federalism, prompts to question its form, and, possibly, its existence. Is Russia building a federation, or is it resurrecting a unitary state?

There are a number of factors that can be useful in tracking the dynamics of Russian federalism to understand and explain it. One such factor is the degree of 
federal symmetry in modern Russia, and the means by which it is achieved. Federal symmetry is relevant to the study of federalism for two reasons. ${ }^{12}$ First, it enables regions of the federation to exercise their constitutional rights assigned to them as a result of a compromise between the federal and regional governments. Second, they determine the degree of regional influence in a federation, and in relation to other regions. I should add that the degree of symmetry is crucial to evolution of federations towards other forms of political structures. In the extreme scenarios it may cause the breakup of a federation (Balkanization) or turn it into a unitary state.

Federations can be symmetrical and asymmetrical. Usually, federal (a)symmetry is used in two respects - socio-economic and constitutional. ${ }^{13}$ For convenience of my study, I distinguish the nature of symmetry in federations as vertical and horizontal: vertical describes the balance of federal power and the power of the units (regions, states); and horizontal describes the comparability of regions among themselves (see Scheme 1, p. 165).

One major groundbreaking article that provides a comprehensive discussion of the vertical symmetry as an element of federalism is by Charles D. Tarlton. His study distinguishes three approaches to the understanding of federalism. First, it is a formal and legal (constitutional) approach, the early proponents of which were Corwin and Wheare. ${ }^{14}$ They study federalism as a legal system, in which neither

\footnotetext{
${ }^{12}$ Ronald Watts, Comparing Federal Systems, 2nd Ed., McGill-Queen's University Press, Montreal and Kingston, Ontario, 1999, p. 65.

${ }_{13}$ Alfred Stepan, Arguing Comparative Politics, New York, Oxford University Press, 2001, p. 326.

${ }^{14}$ See, for example, Kenneth C. Wheare, Federal Government, London, New York, Oxford University Press, 1963.
} 
federal nor regional governments are dependent on one another. The second approach is rooted in the classical Jeffersonian notion that good governance in a federation lies in the distribution of power skewed towards regions and localities (devolution). The third, advocated by Livingston, is the socio-cultural approach to federalism. It is based on federal realism, according to which federalism should be studied not through its own structure but by analyzing the society in the state in which it exists. According to Livingston, society itself contributes a great deal to the structure of federalism. Arguing that federalism is a "universal answer to the question of overcoming problems of diversity and disparity in the interests of harmony and unity," Tarlton warns that this very diversity and disparity within federations should lead to both the increase in local autonomy and in the central authority. ${ }^{15}$ Therefore, federations are fragile structures, and are prone to disintegration, especially if they are vertically and/or horizontally asymmetrical. Regardless of the approach to federalism, Tarlton argues that it is important to analyze it as a system in terms of symmetry and asymmetry.

Horizontal asymmetry is studied by a number of comparative politics scholars and scholars of regionalism. Approaching federalism from a comparative perspective, Canadian scholar Ronald Watts identifies and distinguishes four groups of problematic characteristics of asymmetrical federations. First, is the difference in size of the area, population, living standards, and other attributes. Second, is the mismatch between the existing system and the desires and aspirations of the populace. Third, is

${ }^{15}$ Charles D. Tarlton, Symmetry and Asymmetry as Elements of Federalism: A Theoretical Speculation, The Journal of Politics, Vol. 27, Issue 4, 1965, p. 861-874, at p. 874. 
the mismatch of power among the units of the federation when some can influence federal policy more than others. This is particularly dangerous when the number of units is relatively small, for example, in Canada. ${ }^{16}$. A final problem is the lack of a common language and culture and the absence of mechanisms to protect the rights of all groups from discriminatory policies and actions. ${ }^{17}$ Commenting on the third and fourth outlined characteristics, Watts also argues that the greater the state's homogeneity, the more power is allocated to the federal government. This upsets the vertical symmetry in a federated state. Watts' classification is important to my research on the enlargement of regions. Russia's asymmetrical federalism to some extent possesses all of the four characteristics outlined by Watts, and all of his characteristics are laid in the foundation of my analysis.

A substantial volume of research has been devoted to the subject of Soviet and Russian Federalism. Since Russia is the only federated state of the Former USSR, some of the pre-1991 literature remains relevant to understanding the present nature of Russian federalism. The Western scholars, who always viewed Soviet Federalism as an artificial, if not a fictitious structure, did not define it as asymmetrical. In fact, the ruling communist elites were so sure of the indivisibility of the USSR, that all Soviet Constitutions featured an article, which granted the right to secession to all of the 15 republics - the right which constitutionally justified the breakup of the USSR

\footnotetext{
${ }^{16}$ The same view is expressed by Elazar in Daniel J. Elazar, Exploring Federalism, University of Alabama Press, 1987, p. 244.

${ }^{17}$ Ronald Watts, Comparing Federal Systems in the 1990s, Kingston, Ontario, 1996, at p. 102.
} 
in $1991 .{ }^{18}$ Rather, Soviet federalism was viewed in terms of distribution in the planned economy (Rajabov) ${ }^{19}$, center-periphery relations, elite politics (AriasKing) ${ }^{20}$, ethnic and religious nationalism (Roeder), ${ }^{21}$ the legacy of the Soviet ethnofederalism (Codagnone and Filippov) ${ }^{22}$, and the crafting of the Soviet identity $(\text { Stern })^{23}$. This literature is essential for understanding the theoretical and historical background of Russian federalism.

There are several approaches to studies in Russian regionalism. Their primary difference is in the units of analysis and in field of analysis. Stoliarov, for example, takes a historical and an international comparative approach, studying Russia in contrast with Germany, Switzerland, and the US, and applying the Western federal solutions to Russia. Analyzing the history of statehood in Russia, he identifies many flaws and envisions room for improvement. ${ }^{24}$ Tsiunchuk and a number of other scholars from Tatarstan study the evolution of Russian federalism and argue that the Soviet and Russian experiences should not be ignored in light of the ongoing changes. ${ }^{25}$ The most recent volume by Orttung and Reddaway, for example, employs federal districts as units of analysis of a number of political and socio-economic

\footnotetext{
${ }^{18}$ For example, see Article 72 "Each Union Republic shall retain the right freely to secede from the USSR" in Constitution of the Union of Soviet Socialist Republics, October 7, 1977, Available online at http://www.thisnation.com/library/ussr.html

${ }^{19}$ S. A. Rajabov, Geographic Factors and Certain Problems of Federalism in the U.S.S.R., International Social Science Journal, February 1978, Vol. 30, Issue 1, p. 88-98.

${ }^{20}$ Fredo Arias-King, The Centrality of Elites, Demokratizatsiya, Vol. 11, No. 1, Winter 2003, p. 150-160.

${ }^{21}$ Philip G. Roeder, Soviet Federalism and Ethnic Mobilization, World Politics, No. 43, January 1991, p. 196-232.

${ }^{22}$ Cristiano Codagnone and Vassily Filippov, Equity, Exit, and National Identity in a Multinational Federation: The 'Multicultural Constitutional Patriotism' Project in Russia, Journal of Ethnic and Migration Studies, Vol. 26, No. 2, April 2000, p. 263-288.

${ }^{23}$ Bernhard J. Stern, Soviet Policy on National Minorities, American Sociological Review; June 1944, Vol. 9, Issue 3, p. 229-236.

${ }^{24}$ Mikhail Stoliarov, Federalism and the Dictatorship of Power in Russia, London, New York, Routledge, 2003. Also see G. Allen, "Federalism in Flux," Maclean's, June 24, 1991, Vol. 104, Issue 25, p. 28-33.

25 R. Tsiunchuk, Rossiiskii Federalizm: Istoki, Genezis, Istoricheskii Opyt. Sovremennyi Federalizm: Opyt Perspektivy (Russian Federalism: Sources, Genesis, Historical Experience. Contemporary Federalizm: Experience and Perspectives), Kazan', 1996.
} 
aspects of Russia. ${ }^{26}$ Ruble, Koehn, and Popson undertake a complex quantitative analysis of Russia through the analysis of its "fragmented space."27 Thornton and Ziegler approach Russian federalism by studying larger geographical regions. ${ }^{28}$

In many respects the study of Russian federalism is a study of Russian regionalism in general, and particularly of individual units. The study of the symmetry of Russian federalism is also regional in its scope and nature. In studying vertical symmetry, it is essential to extend the analysis beyond the constitution and other federal laws. Since the degree of vertical symmetry may vary from region to region as a result of the power-sharing agreements between the Russian Federation and its subjects, it is important to study each individual case separately. Volumes on Russian federalism edited by Kempton and Clark and by Ruble, Koehn, and Popson advocate this approach. "Because of the asymmetric nature of Russian federal relations - with each subekt having unique powers and responsibilities - the only viable way to assess the evolution of Russian Federalism is to empirically examine individual cases." 29 For the same reason, it is important to study Russian regions comparatively to assess the horizontal symmetry. Horizontal and vertical dimensions of the Russian symmetry are very relevant to the study of regional enlargement.

\footnotetext{
${ }^{26}$ The Dynamics of Russian Politics: Putin's Reform of Federal-Regional Relations, Edited by Peter Reddaway and Robert W. Orttung, Lanham: Rowman \& Littlefield, 2004.

27 ; Ruble, Koehn, and Popson, 2001.

${ }^{28}$ Russia's Far East: a Region at Risk, Edited by Judith Thornton and Charles E. Ziegler, Seattle, National Bureau of Asian Research in Association with University of Washington Press, 2002. Geographically defined regions roughly correspond to Russia's division into seven federal districts in terms of their longitude in Eurasia.

${ }^{29}$ Daniel R. Kempton and Terry D. Clark, An Introduction to Center-Periphery Relations in, Kempton and Clark, 2002, Chapter 1, p. 7.
} 
It is important to assess the form the relations between the Federation and the enlarged regions are taking. ${ }^{30}$ Since the enlarged regions would not be fully established for a number of years, I can only study the regions in the dynamics of their mergence. Therefore, I assess their merger as a product of the sum of their respective parts. This is reflected in the datasets that $I$ have generated to study the political, economic, and demographic aspects of enlargements.

While Watts outlines the four groups of "problematic characteristics," Kempton and Clark suggest six essential conditions for federalism ${ }^{31}$ and six "beneficial conditions" 32 to federalism. The essential conditions are consensual voluntary participation of units in a federation (this principle echoes the formal constitutional approach of Corwin and Wheare), a written and flexible constitution, adjudication between levels of government, federal representation of subjects, division of power between levels of government, ${ }^{33}$ and political culture of federalism. The six beneficial conditions are the center-periphery balance of power, symmetry among components (which are also Watts' first and second problematic characteristics), federal political parties or a non-centralized party system, noncentralized bureaucracy, democracy, and favorable economic conditions.

\footnotetext{
${ }^{30}$ For example, in Permskii Krai, which is scheduled to become the first of the enlarged regions on December 1, 2005, the existing arrangements between the two former subjects and the federal center would not be abolished at least until 2009.

${ }^{31}$ Kempton and Clark, p. 20.

${ }^{32}$ Kempton and Clark, p. 25-30.

${ }^{33}$ Authors note that division of power in a federation cannot be unilaterally amended. Otherwise, they argue, such state would take a form of loose confederation (if power is altered by components) or a decentralized unitary system.
} 
Commenting on Russian federalism, Kempton defines the asymmetry among the components themselves as problematic as imbalance between the center and the subjects. ${ }^{34} \mathrm{He}$ divides the asymmetry into two main groups: in distribution of resources (political asymmetry) and in terms of legal powers granted by the federation (constitutional asymmetry). These two groups, in turn, create three main problems, which are once again related to Watts' four problematic characteristics. First, donor regions feel they are unjustifiably subsidizing recipient regions of the federation. Second, recipient regions feel resentment towards the donors because they believe that the latter are unjustifiably rich as a result of concessions from the center. Third, the "nested nature of some inter-subekt relationships" complicates federalregional and interregional relations. The third problem is constituted by the infamous matryoshka system, under which autonomous okrugs are subordinate to the oblasts and krais, while being constitutionally equal to them.

Enlargement of the Russian regions is a novelty, and, while enlargement through merger is a work in progress, only two regions have successfully merged. ${ }^{35}$ Therefore, no significant research has been conducted on this phenomenon. Among the few, the most notable is a recent study of J. Paul Goode. ${ }^{36}$ His insightful article sets the background for regional enlargement in the Russian Federation in the analysis of the enlargement of Perm' and Tyumen' oblasts and the debate around it. An author

\footnotetext{
${ }_{35}^{34}$ Daniel R. Kempton, "Assessing Russian Federalism," in Kempton and Clark, 2002, at Chapter 8, p. $202-203$.

${ }^{35}$ Another merger, among Kransnoyarskii Krai, Evenkiiskii Autonomous Okrug, and Dolgano-Nenetskii Autonomous Okrug, has been approved by a referendum on April 17, 2005 with the new subject of the Federation to be officially established on January 1, 2007.

${ }^{36}$ J. Paul Goode, "The Push for Regional Enlargement in Putin's Russia," Post-Soviet Affairs, Vol. 20, No. 3, 2004, p. 219-257. According to Goode, enlargement of regions is a top-down process, in which enlargement is the means rather than the end result.
} 
of a book on internal borders, he focuses his study on the dynamics of the enlargement in light of the administrative reform of Dmitry Kozak ${ }^{37}$, center-periphery relations, and the relations among elites in the regions proposed for merger. Accounting for the complexity of the matryoshka system, interests of certain elites in government and in business, disparity among regions, and other aspects, Goode is not conclusive of the reasons for enlargement. However, referencing Thomas H. Rigby's studies in communist organizational systems, he suggests that the current Russian Presidential Administration, continuing the institutional legacy of the communist past, has initiated the enlargement policy, like it did in creation of the federal districts, to achieve certain goals. "The sensation in today's Russia that it is necessary (even imperative) to reduce the number of regions without a clear underlying rationale, ideology, or end point falls squarely within this ruling tradition." ${ }^{39}$ The goal of my research is to find the underlying reasons for the enlargement by analysis of economic and political reasons, and thus to complement Goode's research.

Finally, the Constitution of the Russian Federation is an important source of my research. In addition to empirical and quantitative data, it constitutes the central piece of my argument. The 1993 Russian constitution determined not only the federative nature and the overall architecture of the state, but also the rights and duties of the state, regions, municipalities, and citizens, many of which are very

\footnotetext{
${ }^{37}$ Kozak, one of Putin's closest aides, is the architect of Russia's administrative reform. The new law "Ob Obshih Printsipah Organizatsii Zakonodatel 'nykh i Ispolnitel'nykh Organov Vlasti Sub 'ektov RF" (On General Principles of Organization of the Judicial and Executive Bodies of the Subjects of the RF) comes into force in 2005. Its primary goal is to reorganize the administrative-territorial division on all level of government and to clarify and delineate spheres of competence at each level by assigning them specific functions. In particular, it transfers most of the fiscal authority from autonomous okrugs to their host krais or oblasts'.

${ }^{38}$ The initially stated goal of the creation of the Federal Districts was to bring regional legislation in compliance with the federal.

${ }^{39}$ Goode, p. 253-254.
} 
relevant in evaluating the arguments for Kremlinization and for economic balancing. ${ }^{40}$

\section{HISTORICAL BACKGROUND: HERITAGE OF RSFSR AND THE PARADE OF SOVEREIGNTIES}

Throughout its long history, Russia underwent a number of major transitions in its territorial structure. Peter the Great was the first Russian monarch to introduce a four-level division - gubernia, province, uezd and volost' - and to bring order to the Empire. However, the first major regional reform was undertaken under the rule of his granddaughter, Catherine the Great. She adopted Peter's general hierarchical division of territory, and divided Russia into 41 gubernii. This structure was inherited by Bolshevik Russia in 1917, and was gradually transformed into the Soviet Union. RSFSR became the largest and the only federal unit of the USSR with federative division within it. Upon the breakup of the USSR, Russia inherited the complex, multi-tier RSFSR structure. ${ }^{41}$

It is essential to understand what is at stake in the ongoing political drive to regional enlargement. First of all, the enlargement is aimed at the elimination of a whole tier of units in the Russian federative construct - the autonomous okrugs. It is, therefore, important to trace the history of the initial formation of the autonomous

\footnotetext{
${ }^{40}$ The Fundamentals of the Constitutional System, Articles 1-16 and The Federal Structure, Articles 65-79.

${ }^{41}$ For a detailed chronology and discussion of the evolution and dynamics of the Russian territorial division, see Irina Merzliakova and Alexei Karimov, A History of Russian Administrative Boundaries (XVIII - XX Centuries), 2001. Online at http:/www.geog.port.ac.uk/hist-bound/papers/russia.htm Also see Richard Pipes, The Formation of the Soviet Union: Communism and Nationalism, 1917-1923, Rev. Ed., Cambridge, MA, Harvard University Press, 1997.
} 
okrugs - to the time when they were first constructed and to understand the rhetoric and the reasoning behind their formation.

Before becoming the Father of Peoples (Otets Narodov), Joseph Stalin proposed his famous "autonomization." He reasoned that the federation of Soviet Republics is based on "common military and economic interests." ${ }^{42} \mathrm{He}$ emphasized the development of republics individually and within the federal system, and called for their diversity, and peaceful coexistence in the RSFSR. Further, Stalin proposed a notion of entities (subjects of federation), which naturally combine a specific manner of life, a specific ethnic composition, and a certain measure of integrality of economic territory. While his understanding of ethno-federalism was originally tailored for larger geographical areas that had enjoyed a degree of autonomy in the late Russian Empire (Poland, Finland, Tatar-Bashkir Area, Kirghiz Area, Siberia, and others), as the Union grew stronger, its scale gradually decreased. Ethnic republics and autonomous areas appeared on the political map of the USSR as a consequence of Stalin's definition of a nation and the emergence of planned economy. ${ }^{43}$ Stalin, like Vladimir Lenin and other Bolsheviks, was convinced that federalism in any form is a transitory stage to socialism. Under socialism, he believed, the federal or unitary form of state would be ultimately irrelevant, as states would disappear as a result of a global revolution. Therefore, Lenin, and later Stalin, proceeded with reshaping the Russian Empire into a pseudo-federation.

\footnotetext{
${ }^{42}$ I. V. Stalin, "Organizatsiya Rossiiskoi Federativnoi Respubliki," (Organization of the Soviet Federated Republic) Sochineniya (Essays), Vol. 4, p. 69.

${ }^{43}$ In his rather primordialist understanding, Stalin defined nation as a historically constituted community with four common characteristics - language, territory, economy, and culture.
} 
At the time of implementation, even Western scholars praised Stalin's ethnic policy. Before the end of the World War II, Stern argued that the successful resistance and counterattack of the Soviet troops is largely rooted in the "extraordinary unity manifested by all segments of the population," which itself is a result of the successful crafting of the Soviet policy towards minorities. ${ }^{44}$ His article focuses on the manipulation of the small ethnic groups by the Soviet policymakers armed with the Marxist conception of class struggle, which renders nationalism, and therefore self-determination, including territorial self-determination, useless.

The Soviet Union was in many respects an artificial construct based on communist ideology, one party systemic hierarchy and planned economy. Its collapse along the borders of its fifteen ethnically defined republics proved the vulnerability of its artificial federative construct. In fact, the system of the declaratory (de-jure) federalism de-facto served as a decoration for cumbersome, corrupt, undemocratic, and inefficient governing. It backfired against its rulers resulting in the greatest disintegration process of the end of the twentieth century. The USSR's collapse invalidated Stalin's approach to ethno-federalism: it proved dysfunctional in a more open and democratic environment. The RSFSR, the only federated and by far the largest constituency of the USSR was spared. Since the breakup of the Soviet Empire, it has not only assumed the role of the legal successor to the USSR, but also as the keeper of its legacy and the strongest partner in modern Eurasia, still able to exert the

\footnotetext{
${ }^{44}$ Stern, 1944. Clearly, at the time of writing the author was unaware of the scale of repressions inside the USSR, and of the series of deportations of peoples from their ethnic homelands - Crimea Tatars, Chechens, and other ethnic minorities.
} 
greatest influence in the former Soviet Union space referred to as the near abroad (blizhnee zarubezh'ie). Russia not only inherited the traditions of the sovereign rule, but also the asymmetric ambiguity of the RSFSR's internal structure. As I have mentioned, contemporary Russia is not the USSR, nor is it the USSR's static and solid fragment. In the early twenty-first century, Russia's internal space remains fragmented, and the federal center is aggressively mediating the process of the enlargement among the 89 Russian regions.

In the years immediately following the declaration of independence of the RSFSR, the signing of the Federative Treaty, and the adoption of the Russian Constitution, the federal government signed power-sharing agreements (treaties) with half of the Russian regions. ${ }^{45}$ The delegation of broad autonomy from the center to regions was a landmark of Yeltsin's presidency. The first treaty was concluded with Tatarstan on February 15, 1994 to contain the strong independence (and secession) demands of the Tatar nationalists. It was followed by the so-called parade of sovereignties: 2 more treaties were inked in 1994, 4 in 1995, 17 in 1996, 12 in 1997, and 6 in 1998. By the time of the Russian financial crisis and default in August 1998, a total of 42 individual treaties and 46 federal-regional treaties were enacted. ${ }^{46}$ Overall, Yeltsin's policy towards federalization in terms of allowing the subjects to take "as much authority as they could swallow" prevented further breakup of the

\footnotetext{
${ }^{45}$ Federation Treaty, signed in Moscow on March 31, 1992, declared RSFSR's independence from the Supreme Soviet authority. Online at http:/www.cityline.ru/politika/doc/fd.html (in Russian). The Treaty reflected the struggle for political leadership between Gorbachev and Yeltsin. Yeltsin effectively used the regions' aspirations for greater autonomy and independence against Gorbachev. The Treaty was signed by all of the RSFSR's constituencies except the Republics of Chechnya and Tatarstan.

${ }^{46}$ Full list of Treaties is available in Russian online at http:/www.cityline.ru/politika/reg/dogovory.html Among other regions, three matryoshkas - Perm' Oblast' and KPAO, Irkutsk Oblast' and U-OBAO, and Krasnoyarsk Krai and Taimyr and Evenkia - signed power-sharing agreements with the Federation.
} 
state. However, his policy failed to adequately resolve the territorial and political disputes in the North Caucasus. Chechnya found itself in the position to claim the full status of Soviet Socialist Republic (SSR) upon the return of Chechens deported to Central Asia during World War II and separation from the Checheno-Ingushskaya Autonomous Soviet Socialist Republic (ASSR). ${ }^{47}$ The newly established Russian Federation lacked the political leadership to quell rebellious Chechnya, one of its 89 constituencies, peacefully. The conflict deteriorated into a bloody war as Russia remained determined to retain the full territory it had inherited from RSFSR. Ten years into the disastrous military standoff, the status of Chechnya in the Russian Federation remains uncertain.

In retrospect, it is undisputable that the 1990s Russia was a state of weak central authority and rule of law. Unable to deal with the growing centrifugal processes in the country, the "generous" delegation of federal authority might have been one of the few, if not the only option short of force, to preserve the integrity of the state through turbulent times of change.

\footnotetext{
${ }^{47}$ While ASSRs were formed as ethnic constituencies within the RSFSR, SSRs were formed in large ethnic republics with international borders as constituencies of the USSR. ASSR could petition for the upgrade of their status to SSR, if they satisfied the general Soviet requirements for SSRs - ethnic (titular) nationality's population of over one million, a majority of titular nationality in total ASSR's population, absence of ethnic republic of the given ethnicity elsewhere in the Union, and existence of international borders in the ASSR. Upon the breakup of the USSR, and secession of the Georgian SSR, the Chechen ASSR satisfied the requirements. Had it been granted the SSR status, it could then legitimately seek secession.
} 


\section{GOSUDARSTVENNOST'AS LINCHPIN OF PUTIN'S DOMESTIC POLICY}

Since Yeltsin's resignation, the tide of the parade of sovereignties changed, as the federal government's policy has been redirected at countering the forces of decentralization. Putin's first electoral campaign was launched under the slogan of gosudarstvennost' - the notion of statehood and rule of law, implying the idea of a stronger state. ${ }^{48}$ Putin has taken several practical steps to bring this idea of statehood to life.

First, upon the beginning of his first term and based on strong national support, the second Chechnya military campaign was initiated after three years of uneasy coexistence of the Republic and Moscow. The purpose of the ongoing campaign was to enforce the Russian rule over the rebellious constituency. Second, six months into his tenure, in May 2000, the President signed a decree dividing the federation into seven federal districts (federal'nye okryga), and presidential special envoys (polnomochye predstaviteli, or polpreds) were delegated to each of them to ensure the compliance of the regional legislation to the constitution and the federal laws. ${ }^{49}$ This new tier of federal government, closely corresponding to Russia's division into military districts and court districts, and overlapping the economic

\footnotetext{
${ }^{48}$ See detailed discussion on the concept of Putin's gosudarstvennost' in John Squier, Civil Society and the Challenge of Russian Gosudarstvennost, Demokratizatsiya, Vol. 10, Issue 2, Spring 2002, p. 166-182.

${ }^{49}$ Institute of polpreds created a new tier of executive power. Unlike Yeltsin's presidential representatives to regions, polpreds to the federal districts are positioned higher in the executive branch. They retain closer ties to the president, and maintain distance from regional governors. For a detailed analysis on Putin's reforms, see James Alexander, Federal Reforms in Russia: Putin's Challenge to the Republics, Demokratizatsiya, Vol. 12, No. 2, Spring 2004, p. 233263 and Robert Sharlet, Resisting Putin's Federal Reforms on the Legal Front, Demokratizatsiya, Vol. 11, Issue 3, Summer 2003, p. 335-342.
} 
districts established during the Soviet period and the interregional economic interaction of the last fifteen years, was established to ensure the regional compliance with federal legislation, primarily the Constitution. Federal Districts (FDs) have become a "virtual scaffolding" for rebuilding the Russian state (see Map 3, p. 173) . $^{50}$ Since 2000, the institute of polpreds, appointed from among the most trusted of Putin's associates, has grown substantially stronger. Third, the establishment of the FDs was followed by the reform of the upper chamber of the Russian legislature, the Federation Council (Soviet Federatsii) by which the governors were effectively replaced by regional representatives in this federal body. Fourth, in March 2004 the administrative reform advanced further through the reorganization of the executive branch as the number of federal ministries was halved. Finally, the biggest cut to the power of the regions was implemented in September-December 2004, in the aftermath of the Beslan school terrorist attack. The latest reform replaced the elections of regional governors by popular vote with the system of presidential appointment upon the approval of regional legislatures. ${ }^{51}$ In addition, large-scale federal and regional budgetary reform, reform of social security and state benefits, and reform of local (municipal) government are being implemented throughout 2005.

In this context of swift changes in the Russian political power structure, the enlargement of Russian regions comes as no surprise. Launched in November 2003

\footnotetext{
${ }^{50}$ Hill and Gaddy suggest "Federal Districts are simply another effort to create artificial connections across Russian territory." In Fiona Hill and Clifford Gaddy, The Siberian Curse: How Communist Planners Left Russia Out in the Cold, Brookings Institution Press, Washington DC, 2003, at p. 116.

51 A number of scholars argue that federalism form from separate states and confederations in response to security threats. Possibly, Putin's admission to state's weakness after Beslan has boosted the enlargement drive. See, for example, Peter H. Merkl, Modern Comparative Politics, New York, Holt, Rinehart and Winston, 1970, p. 247. Albert $V$. Dicey takes the notion of federalism further and views it as a transitory stage between separate states and unitary states, in Kempton and Clark, p. 20. Possibly, the enlargement of Russian regions would add validity to his claims.
} 
with a referendum on the establishment of Permskii Krai by merger of two subjects of the Federation - Perm' Oblast' and Komi-Permyatskii Autonomous Okrug (KPAO), it is planned to continue in 2005. The pilot merger project to form Permskii Krai would be officially completed on December 1, 2005 with the "elections" of the governor and the legislature of the new region.

\section{THE REGIONAL ENLARGEMENT DEBATE}

Russia's internal borders inherited from the RSFSR and their reform have been a source of debate since the breakup of the USSR. The borders, many argue, were suitable for the RSFSR as a nominally federative republic and were operational units under the system of top-down administrative control. ${ }^{52}$

There are four major currents in the regional enlargement debate. They are proponents of unitary state, supporters of the present administration's policies, advocates of enlargement for personal and corporate gain, and those who oppose enlargement.

Proponents of unitary state in Russia are usually left-wing parties, nationalist sentiment of the population, and a significant portion of the population, particularly those who spent considerable parts of their lives in the USSR and are reminiscent of the security and stability of life in the centralized communist system. In addition,

\footnotetext{
${ }^{52}$ Gennady Oleinik, the Chairman of the Federation Council Committee on the Northern Areas and Small Peoples, in "Ychastniki "Kruglogo Stola," Posvyashennogo Ykrupneniu Regionov RF, Predosteregaut ot Pospeshnogo Ob'edineniya Rossiiskikh Regionov (Participants of the "Round Table" on the Enlargement of Russian Regions Warn Against Hasty Enlargement), RIA Novosti, July 15, 2004. Also see James Alexander, "Federal Reforms in Russia: Putin's Challenge to the Republics," Demokratizatsiya, Vol. 12, Issue 2, Spring 2004, p. 233-263.
} 
some representatives of Russian intelligentsia and monarchists view a unitary state as Russia's salvation. As early as 1990, Alexander Solzhenitsyn, a literary Nobel Prize laureate, contended that "the body of Russia is cracked" and that it should embark on an evolutionary path towards a unitary state" in order to preserve its statehood. ${ }^{53}$ Vladimir Zhirinovskii, the Deputy Speaker of the Russian Duma and the Head of Liberal Democratic Party of Russia (LDPR), has long suggested the simplification of the national-territorial division of Russia through a transition to purely territorial division into nine or fifteen gubernias, and consequently - to a unitary state. He contends that the creation of seven federal districts should be the first step in this process. Zhirinovskii argued that this change would be aimed at "liquidation of interethnic disputes, suppression of national separatism, optimization of the economic development of regions and intensification of interregional ties." ${ }^{\text {,54 }}$ Although Zhirinovskii mentions the economic argument for enlargement, like most politicians, he doesn't spell it out. His rhetoric is based on the intrinsic great power chauvinism, which has been fuelling his electoral votes since the early 1990s. Vladimir Shumeiko, former Chairman of the Federation Council of Russia, takes a similar approach: "because of various historic, demographic, geographical, economic, military, and political causes, only Russia can become a nucleus of the new system of states on the territory of the former USSR." 55 To him, the starting point for preparing Russia for its new historic role of a unifier of Eurasia is the strengthening of the federal power in Russia through "reduction of the number of constituent parts by merging them."

\footnotetext{
${ }^{53}$ In Vera Brychyova, Oleg Gorbatov, and Elena Korotrova, "Gubernskii Peredel" (Rearrangement of Gubernii), Moskovskii Komsomolets, July 1, 2003.

${ }^{54}$ Vladimir Zhirinovskii: Rossiya Idyot k Sozdaniu Unitarnogo Gosudarstva. Vmesto 7 Federal'nykh Okrugov Budet 15 Gubernii (Russia Moves Towards the Creation of a Unitary State. 15 gubernii will Subsitute 7 Federal Districts), March 30, 2004, www.regnum.ru

${ }^{55}$ Interview in Kommersant, No 184, October 3, 2000.
} 
Many current federal-level political figures agree with the course on enlargement of regions or appear to have taken a neutral conformist stand on the issue. Both positions are supportive of Putin's administration policy. The latest Duma elections of November 2003 have turned the Russian Parliament into the rubberstamp of the executive branch. The executive branch, formally headed by a prime minister is in fact subordinate to the President and his administration. The centrist propresidential majority in the Duma is represented by the largest Russian political party United Russia. Its dominance guarantees that almost any legislation, including that regarding the enlargement of regions, submitted by the President, PM, or ministers would be approved. However, even some non-centrist politicians support the enlargement process. Irina Khakamada, former Deputy Speaker of the Russian Duma and an active right-wing politician ${ }^{56}$, believes that the regions of Russia should be enlarged to enhance the governance of the country because "the president doesn't have enough time to meet with eighty-nine regional leaders." ${ }^{57}$ Khakamada also recalled the positive experience of the twelve economic associations in 1990s, and argued that their contours could serve as basis for creating twelve subjects of the Federation with numerous functions and vast autonomy. However, her former Union of Right Forces Party (Soyuz Pravykh Sil) co-chairman Boris Nemtsov, who was also governor of Nizhnii Novgorod Oblast' and deputy premier of Russia, has expressed the opposite opinion: "enlargement of regions would impede the interaction between

\footnotetext{
${ }^{56}$ Liberals are regarded as right-wing politicians in the Russian political spectrum. Zhirinovsky's LDPR in fact used to be a left-wing party until it grew overly conformist towards the center, which is somewhat neutral and increasingly propresidential.

${ }_{57}$ Interview in Regnum News Agency, May 30, 2003, www.regnum.ru
} 
the people and the power; it would be harder to reach the governor of a large region." 58

A number of political and economic players have attempted to hijack the policy of the Putin-Kozak tandem, and harness the enlargement drive to serve their causes. This group primarily includes oligarchs, their lobbyists, and some powerful governors of non-ethnic constituencies. The debate particularly heated up since the introduction of seven federal districts, and a number of new merger proposals immediately followed. Aman Tuleev, Governor of Kemerovo Oblast', contends that Russia needs no more than fifty subjects, which are to be formed by merger of regions of "interconnected and complementing industrial structure" in order to simplify governance. ${ }^{59} \mathrm{He}$ further emphasizes that the autonomous okrugs ought to be merged first. Tuleev's argument is grounded in more or less objective economic assessment of the federal structure of Russia, pragmatic regional policy, and his personal goals to facilitate the development of transportation infrastructure at the expense of the federal government. Such developments would enable him to ship Kuzbass Basin coal across Eurasia faster and cheaper.

Several more "exotic" plans have been proposed for the future territorial division of Russia. Vyachslav Bel'dei, Aleksandr Sobyanin, Vladislav Turabov and

\footnotetext{
${ }_{59}^{58}$ Interview in Nizhny Novgorod, June 18, 2004, online at www.regnum.ru/news/279976.html.

${ }^{59}$ Aman Tuleev was among the first regional politicians to implement enlargement by creating an economic organization known as "The Siberian Accords" (Sibirskoe Soglashenie) in 1990. He also advocated the idea of regional enlargement during his presidential campaign in 2000. Inna Kovina, "Dva Pishem - Odin v Yme, ili Nyzhna li Rossii Administrativno-territorial'naya Reforma," (Writing Two - Keeping One in Mind, or Does Russia Need Administrativeterritorial Reform), Rossiiskaya Gazeta, March 23, 2004, online at www.rg.ru/2004/03/23/tuleev.html Tuleev is the last governor who was originally appointed by Yeltsin in mid-1990s.
} 
German Khrustalyov are the architects of one of them. They propose to redraw the existing seven federal districts and create fifteen FDs to be headed by polpreds with vast authority ${ }^{60}$ Among other districts, they particularly advocate the creation of the Northern Federal District to include St. Petersburg, Leningrad Oblast', Pskov Oblast', Novgorod Oblast', redistricted Archangelsk Oblast', and new Nenets Krai, Taimyr Krai, and Kolyma Krai with the district's capital in St. Petersburg. With Khrustalyov, whom I met when he was the Chairman of the Russian Political Movement Obshestvennoe Soglasie (Public Consent), now being the deputy director of Norilsk Nickel in Moscow (MFK Noril'skii Nickel'), the ultimate objective of the proposal to redraw FDs in such manner is clear. It is an attempt to lobby for the natural monopoly's interest. The intention must have been to stop the City of Noril'sk from integration in Krasnoyarsk Krai and thus to protect the regional nickel oligarchy under the pretext of development of the Russia's North through its integration. Noril'sk, a city built in permafrost next to Russia's largest nickel deposits, subordinates directly to Krasnoyarsk and its charismatic businessman-turnedgovernor Aleksandr Khloponin. ${ }^{61}$ Khrustalev's plan to divert the city from the control of the south is doomed to fail since the enlargement of the Krai through merger of Taimyr, Evenkia, and Krasnoyarsk will put Norilsk under firm control of the enlarged region.

\footnotetext{
60 “15 Okrugov Rossii,” (15 Russia's Districts), Regnum News Agency, April 8, 2004, Online at www.regnum.ru/news/243722.html 
The reforms do have some relatively strong opponents, including regional governors who are reluctant to part with their fiefs and the accompanying federal privileges and region-based natural monopolies willing to maintain their advantageous resource bases and market networks. These groups, along with the remaining right-wing politicians are the only "true" Russian federalists. Many of the ruling regional elites and businessmen would be unlikely to support the regional and federal initiatives unless sizeable economic benefits are involved. This holds true for popular governors of resource-rich regions, for example, governor Yuri Neelov of YaNAO and Aleksandr Filipenko of $\mathrm{KhMAO}^{62}$. Russia's ethnic republics and some autonomous okrugs (AOs) also express their opposition. It includes the Buriat republic and AOs that have been expressing their desire to form a single Buriat Republic rather than be merged with ethnic Russian-dominated oblasts and krais. ${ }^{63}$ Before the creation of Federal Districts and the introduction of the mechanism of appointment of governors, other ethnic republics, particularly the Republic of Sakha (Yakutia) and the Muslim republics of Tatarstan and Bashkortostan balanced between the policy of decentralized federalism (devolution) and full independence (secession). Their position on the enlargement of regions and establishment of unitary state in Russia has always been outright negative.

Some federal executives also oppose enlareement. Deputy Head of the Central Administration of the Russian Ministry of Justice for the Republic of Dagestan (Glavnoe Upravlenie MinYusta) Sabir Davudov suggests that there are too many

\footnotetext{
${ }^{62} \mathrm{I}$ discuss the case of KhMAO and YaNAO in the subsequent chapters.

${ }^{63}$ Buriat constituencies include U-OBAO (in Irkutsk Oblast'), Buriat Republic (Buriatia), and Aginskii Byruatskii AO (in Chita Oblast').
} 
sensitive ethnic issues involved in the enlargement process, and that the enlargement should not be a simple "arithmetical" task. ${ }^{64}$ Moreover, he contends that the governance of the large and unpopulated northern regions would actually become harder should the regions merge. Sabirov's arguments are based on the facts that Russia is an extremely large multinational state, where certain non-immigrant ethnicities have been compactly residing in their respective territories for centuries, and that Russia has its own unique path of development. The notion of the "uniqueness of Russia" is a common argument used to dismiss both Western (democratic) and Eastern (authoritarian) paths of development models for Russia. ${ }^{65}$ Sabirov, however, does not dismiss enlargement based on socioeconomic necessity and through referendum. Like many, he opposes the Zhirinovsky-style plans to redraw Russia's internal borders arbitrarily (arithmetically).

Despite strong opposition, Aleksandr Kazakov, the Chairman of the Federation and Regional Affairs of the Federation Council, voiced one such proposal. Meeting with journalists on May 20, 2004, he proposed to divide Russia based on the model of Catherine the Great - into twenty-eight gubernii. ${ }^{66}$ Among others, he proposed the creation of North Caucasus (Severo-Kavkazskaya) gubernia to include the republics of Dagestan, Ingushetia, Kabardino-Balkaria, and North Ossetia, and Stavropol' Krai with a capital in Stavropol'. Such proposals are premature, if not

\footnotetext{
64 Interview with Sabir Davudov by Regnum News Agency, April 19, 2004, online at www.regnum.ru/news $/ 248767 . \mathrm{html}$

${ }^{65}$ To justify Russia's backwardness, or an irrational act, Russians often reference a famous proverb "Umom Rossiu ne poniat ', arshinom obshim ne izmerit." 'It is well summarized in Winston Churchill's famous description of Russia as of "a riddle wrapped in a mystery inside an enigma."

66 "Novyi Variant Administrativno-Territorial'nogo Deleniya Rossii," (New Variant of the Administrative-Territorial Division of Russia), Regnum News Agency, May 20, 2004, online at www.regnum.ru/news/264405.html and Aleksei Pavlovskii and Natalia Svyatoslavskaya, "Ug Rossii Hotyat Podelit' na Tri Chasti," (Russia's South May Be Divided in Three Parts), Kommersant Volgograd, No 91, May 22, 2004.
} 
outright dangerous, as they clearly do not enhance the prospects for the peace process in Chechnya. Further, Kazakov takes a more pragmatic and rational stand and outlines three issues linked with the enlargement of regions. First, he argues that the existing number of subjects is simply too large to manage in terms of harmonious vertical and horizontal federalism. Second, the existence of complex regions with autonomous okrugs (slozhnosostavnye sub'ekty) breeds numerous economic, social, and governance problems. Third, regions should be self-sufficient not only in the juridical framework of the constitution, but be able to fulfill their federal and regional functions. ${ }^{67}$

Finally, President Putin believes that "merging some regions is justified," and that "the purpose of merging the two regions (Perm Oblast' and KPAO) is to create broader opportunities for their economic and social development and increase the effectiveness of the regional and local authorities' work. "68 The chief of presidential administration, Dmitry Medvedev, supports the President's position. Speaking about the future "face" of Russia, he accentuates that "the idea of the enlargement of regions is a variant of thoughtful development of the federation within the framework of the existing Constitution." ${ }^{69}$ Most federal politicians, including the Duma speaker Sergey Mironov, the Chairman of the Federal Elections Commission Aleksandr Veshnyakov, and the Chairman of the Supreme Court of Russia Vyacheslav Lebedev contend that the enlargement is justified as long as it is conducted in compliance with

\footnotetext{
${ }^{67}$ Sergey Medvedev, "Matryoshka Ukrashaet Federatsiu," (Matryoshka Decorates the Federation), Rossiiskaya Gazeta, April 1, 2004, online at www.rg.ru/2004/04/01/region.html

${ }^{68}$ In the Spotlight, October 31, 2003, Official Website of the President of Russia. Online at Www.kremlin.ru/eng/text/themes/2003/10/312052_54807.shtml

${ }^{69}$ Valery Fadeev, "Sohranit' Effektivnoye Gosudarstvo v Sushestvyushikh Granitsah," (To Preserve an

Functioning State in Present Borders), Interview of Dmitry Medvedev in Expert, \# 13 (460), April 4, 2005.
} 
the federal law and through referendum. Andrei Klimov, one of the drafters of the merger scheme for Perm' Oblast' and KPAO has suggested that the number of Russian regions would decrease to $60-65$ by 2008 (See Table 1, p. 175). ${ }^{70}$ That is the year Vladimir Putin's second presidential term will expire.

Overall, the openness of the regional enlargement debate is encouraging, as it would hopefully result in a more balanced and pragmatic policy. However, politicians are not the only actors in the enlargement process. The overwhelming majority of them agree that the ultimate decision of the enlargement is made by the citizens of the respective regions through a referendum. According to the December 2003 VTSIOM poll, 62 percent of Russian citizens view regional enlargement as a positive idea while only 17 percent express a negative attitude towards it (see- VTSIOM Survey, p. 39). I treat this survey data with caution because, as later chapters and conclusions show, the survey results may be quite inaccurate. I doubt that polls were conducted in resource-rich regions and in regions of the Southern $\mathrm{FD}$, as their standing on the enlargement tends to be negative. Moreover, Russia's North Caucasus republics express their resolve to further break up (in case of Karachaevo-Cherkesia and Kabardino-Balkaria) or to secede from the Federation (in case of Chechnya), rather than to merge and form larger constituencies. Russia's ethnic republics may take a neutral stand on the enlargement as long as it does not infringe their territorial integrity. ${ }^{71}$ The smaller ethnicity-based constituencies - autonomous okrugs - tend to

\footnotetext{
${ }^{70}$ Tamara Shkel', "Edinaya Rossiya" Pravit Geografiu,” (“United Russia" Corrects Geography), Rossiiskaya Gazeta, April 15, 2004, Online at www.rg.ru/2004/04/15/edinaja.html

${ }^{71}$ Strong proponent of federalism Stoliarov, who also serves as First Deputy Representative of Tatarstan to the President of the RF in Moscow and maintains ties to Tatarstan's President Shaimiev, suggests "perhaps it would be
} 
look towards the prospects of enlargement more favorably. Being among the poorest regions in the Federation, they see little political risk in enlargement, and hope that their merger with the richer neighboring constituencies would stimulate their economies.

\begin{tabular}{|l|c|}
\hline \multicolumn{1}{|c|}{ Attitude of Russians towards the Enlargement of Regions } & $\%$ \\
\hline $\begin{array}{l}\text { Positive, because it would cut down the bureaucratic apparatus and enhance } \\
\text { Russia's governance }\end{array}$ & $\mathbf{3 1}$ \\
\hline $\begin{array}{l}\text { Positive, because it would provide an opportunity to increase the } \\
\text { effectiveness of solution of economic and social problems locally }\end{array}$ & $\mathbf{2 3}$ \\
\hline $\begin{array}{l}\text { Positive, since it would allow to unite peoples of similar cultural and } \\
\text { national traditions }\end{array}$ & $\mathbf{8}$ \\
\hline $\begin{array}{l}\text { Negative, since it would require amending the Constitution and may } \\
\text { negatively affect the socio-political stability of the state }\end{array}$ & $\mathbf{8}$ \\
\hline $\begin{array}{l}\text { Negative, since it may further increase the gap between the "rich" and the } \\
\text { "poor" regions }\end{array}$ & $\mathbf{9}$ \\
\hline Never thought about it & $\mathbf{1 8}$ \\
\hline I am indifferent & $\mathbf{9}$ \\
\hline Hard to say &
\end{tabular}

Source: "Ukrupnenie Regionov: Podderzhka Rossiyan Garantirovana" (Enlargement of Regions: Support of Russians is Guaranteed), VTSIOM, Press-release \# 41, December 8, 2003

All-Russia Center for Study of Public Opinion (VTSIOM) conducted an express-poll asking Russian citizens the following question: "What is your attitude towards the decrease in the number of the Russian regions by merger (enlargement) of some of them?"

The poll has shown the majority of Russians ( $62 \%$ against $17 \%$ ) have a favorable attitude towards this idea. A third of the respondents believe that it would cut down the bureaucratic apparatus and enhance Russia's governance. Another $23 \%$ envision the opportunity to increase the effectiveness of solution of economic and social problems locally.

The all-Russia poll was conducted on November 15-16, 2003 in 100 inhabited locations in 39 oblasts, krais, and republics of Russia. 1600 people were polled at location of their residence. Statistical error does not exceed $3.4 \%$.

necessary to alter the status of some of the constituent parts by merging them in order to form larger economic formations." Stoliarov, 2003, at p. 171. Clearly he is not referencing Tatarstan. 


\section{AUTONOMOUS OKRUGS: BRIEF HISTORY AND CURRENT STATUS IN THE FEDERATION}

All cases of regional enlargement studied in this paper involve the complex subjects of the Federation - oblasts or krais and autonomous okrugs. It is essential to review the nature of autonomous okrugs and their current status in Russia to understand why they are the first (and possibly the only) regions headed for merger.

Stalin first established autonomous okrugs ${ }^{72}$ as administrative-territorial units of the RSFSR in the 1920-40s to accommodate culturally distinct and compactly residing ethnic minorities, whose geographic location and population did not satisfy the criteria for assigning them a status of ASSR or SSR. ${ }^{73}$ Stalin considered aboriginal cultures of some ethnicities inferior and underdeveloped in relation to other cultures of the USSR. There were two major reasons for this. First, these ethnicities still practiced paganism and many of them led a nomadic life. Soviet policy was very intolerant towards religion and promoted scientific atheism, and the emerging authoritarian state was anxious to establish total control over peoples' residence and movement. ${ }^{74}$ Second, according to Marx, their society had not passed through the evolutionary stages necessary for a socialist revolution (even the Russian Empire was not "mature" enough for the revolution). Many of the ethnic groups of the north and Siberia were neither agrarian nor industrial societies due to

\footnotetext{
${ }^{72}$ Originally, autonomous okrugs were named national okrugs (natsional'nyi okrug). They were renamed "autonomous" with the adoption of the last Soviet and RSFSR Constitutions. Apparently, this change was instituted to emphasize relative autonomy of the okrugs and de-emphasize their ethnic component. It remained in constituencies' names regardless (Komi-Permyatskii, Khanty-Mansiiskii, and other).

${ }^{73}$ Their constituencies did not border foreign states, and their titular populations were less than one million, although they constituted the majority in the autonomous okrugs before the establishment of prison camps and the major resettlement of other ethnos to the North and to the Siberias.

${ }^{74}$ Stalin's policy of education and integration was suppressive and discriminatory towards the traditional cultures of the autonomous (national) okrugs. Their collectivization, Russification, and Sovietization were conducted by major propaganda campaigns. See Poster 1 on p. 169.
} 
their geographic isolation and harsh environment. Therefore, new Soviet institutions were required to facilitate their integration. Establishment of autonomous okrugs as subunits of larger ethnic Russians-dominated regions created such institutions.

The nested nature of the ten AOs in the RSFSR's structure was maintained until the disintegration of USSR, with Russia inheriting the territorial-administrative structure of the RSFSR. Fearing further disintegration, it promptly reconfirmed the state's federated nature, first, in the Union Treaty (Federative Treaty) and then in the Constitution. AOs gained the momentum to declare their independence from their host regions to be constitutionally recognized as independent federative units. At the same time, AOs partially retained special relations with their host regions. These relations, according to Article 66-4 (see Appendix 4, p.164), "may be regulated by the federal law or a treaty between the bodies of state authority of the autonomous area (AO) and, accordingly, the bodies of state authority of the territory or region (krai, oblast')." AOs can form equal partnerships with their host regions. Constitutionally, matryoshkas are not included into one another. This norm was confirmed in the ruling of the Constitutional Court of the RF, which clarified that "AO's location in krai or oblast' or AO's secession from it does not affect its legal constitutional status (konstitutsionno-pravovoi status) as well as on the legal-national system (natsional'no-pravovoe ustroistvo) or the composition of the RF; AO's location in krai or oblast' does not stipulate acquisition of its territory, which is a composite part of the RF.",75

\footnotetext{
${ }^{75}$ Ruling on the status of Chukotka Autonomous Okrug, the Constitutional Court of the Russian Federation, May 11, 1993 , VKS, 1994, \#2-3, p. 54)
} 
There are now ten AOs in Russia, but only Chukotskii AO is a fully independent region. The other nine are parts of matryoshkas. There is a total of seven matryoshkas in Russia. Their number is to decrease to five upon merger of two AOs (Taimyr and Evenkia) with Krasnoyarsk Krai and one (KPAO) with Perm' Oblast'.

The Constitution does not specify relations among the other five types of regions. None of them are considered nested within other regions. According to Article 5-1 of the Russian Constitution, the state consists of "republics, territories, regions, cities of federal importance, an autonomous region and autonomous areas (okrugs) - all being equal subjects of the Russian Federation" and, according to article 5-4, equal among themselves and with relation to the Federation. Despite the established equality among the subjects, article 5-2 makes the first distinction among the regions. While "republics (states) shall have own constitution and legislation," the other five types of regions "shall have charters and legislation." Also, they are not referenced as "states" in parenthesis. This raises the question of the equality in status: if indeed all regions were equal, why would they be assigned different names with republics nominally possessing attributes of sovereign states? Moreover, it raises the question about the meaning of the "state integrity, the unity of the system of state authority, the division of subjects of authority and powers between the bodies of state power of the Russian Federation and bodies of state power of the subjects of the Russian Federation, the equality and self-determination of peoples in Russia," established in article 5-3. 
Indeed, major differences exist in status of the subjects of the federation despite their declared equality. Inequality among them is often attributed to the Soviet ethnic policy and planned economy. Present inequality (vertical and horizontal asymmetry) is in addition the result of the 1990s parade of sovereignties. The early post-Soviet leadership neglected to take the regional reform to the constitutional level and showed its incapacity to adequately address the secessionism in the young Federation. Federal asymmetry deepened across the state, and Yeltsin's poorly formulated regional policy culminated in the war in Chechnya.

On the political front, regional policy was often conducted independent of federal policy and in disregard of Russia's Constitution. Some regions developed close ties to the federal government, while others estranged themselves from federal affairs. On the economic front, some regions like the City of Moscow and parts of Khanty-Mansiiskii AO used their competitive advantages to create booming economies, while economy stagnated and declined in the majority of regions. Poor, cold, and remote AOs have been among the worst hit subjects of the Federation. Their nested status in other subjects has inspired proposals to boost their socio-economic standing by merging with the neighboring regions. Such neighboring regions are usually the former host regions of AOs, and are often, but not necessarily, more prosperous. In fact, the enlargement of regions by merger of AOs and their former host regions is the reversal of the parade of sovereignties. Should all AOs be merged, the Russian Federation would reinstate most of the pre-1990 RSFSR internal borders. 
In the following chapters I assess the demographic, political, and economic aspects of regional enlargement. Subsequently, I assess the changing status of AOs in light of the regional enlargement. Finally, I outline the implications of the regional enlargement on Russia's federal symmetry. 


\section{CHAPTER II. DEMOGRAPHICS OF REGIONAL ENLARGEMENT}

\section{POPULATION-TO-LANDMASS RATIO}

Population of the Russian Empire coupled with its landmass has always created advantageous conditions for growth and expansion, the single obstacle to expansion being the harsh climate of large areas of Siberia and the Far East. Division of the growing empire into administrative-territorial units accounted the population as one of vital regional characteristics. Population size was factored in for military and taxation reasons. The status of "gubernia" (super region) was originally granted by the state to a territory if it satisfied certain minimal requirements. It had to contain a town or city (center, capital) and at least 300,000 men available for conscription. ${ }^{76}$ Subsequently, more criteria were introduced, and constituencies of different status were created in Russia. As I noted earlier, throughout the Soviet period certain criteria of size of the population, geographic location, and ethnic composition were applied to determine status of Soviet Republics, and units within the RSFSR.

Twenty-first century Russia faces a governance dilemma of governing territory or people, and of the extent to which the multiethnic composition of the state should be imbedded in its federative structure. Should the constituencies be symmetrical in terms of their area, in terms of their population, or in terms of their ethnic composition? The

\footnotetext{
${ }^{76}$ Hill and Gaddy, 2003, p. 107.
} 
current government tries to accommodate all three characteristics in a more symmetrical federation. If this observation is accurate, then enlargement of Russian regions may be the first logical step towards greater federal control and more efficient governance given the skewed population-to-landmass ratio (See Map 4 p. 174).

I argue that the rapid demographic changes in Russia constitute a significant factor in the current trend of regional enlargement. Inefficient governance in Russia may be in part attributed to the asymmetry of regional landmass and population (See Table 4, p. 179). Given the different impact of the demographic crisis in areas of the country, different size of constituencies, and the growing asymmetry among them, it is challenging to choose the rational way to efficiently govern Russia. On the one hand, the dwindling grip of federal authority over Far Eastern landmass arguably poses a security threat from China, and, therefore, Russians should resettle border territories. On the other hand, given the climatic conditions, much of Russia's territory is unsuitable for accommodation of larger and denser communities. Even should the population of Russia dramatically increase, much of its territory may always remain sparsely populated.

In this chapter, I assess three demographic aspects of Russian regions that I find important factors, and, possibly, prerequisites for regional enlargement. I first overview the current demographic situation in the regions proposed for enlargement. Then I explore the phenomenon of concentration of population in urban centers as a possible advantage to the realization of the enlargement policy. Third, I analyze the dilution of titular (which are also indigenous to autonomous okrugs) ethnicities in the autonomous 
okrugs as a consequence of the enlargement policy. Finally, I assess the demographic aspect of the enlargement of regions as a factor contributing to greater federal symmetry.

\section{DEMOGRAPHIC CRISIS OF THE 1990s}

Article 27-1 of the Russian Constitution guarantees "the right to free travel, choice of place of stay or residence" to every person, legally staying in Russia. However, population movement across Russia is handicapped by a number of conditions rooted in the state's size and its geographic and climatic conditions. The vestiges of Soviet systems of propiska and raspredelenie (registration and allocation or distribution of the population) further exacerbate population immobility. Russia's economy can hardly sustain the system and the structure it inherited from the USSR. While the old ties of the planned economy have been broken and many industries have been shut down or reorganized, only few new ones have replaced them. The economic conditions don't create enough opportunity across the state's territory. A number of subjects (and parts of subjects) of the Federation are simply economically unviable without significant federal and regional aid.

As a consequence of the economic downturn in the 1990s, the population of Russia has shrunk. It is estimated to have lost around 3.5 million people since the breakup of the USSR, ${ }^{77}$ and as many as 0.7 million people in 2004 alone. The current population is estimated at 143.4 million people, or about 2 million fewer than the last all-

\footnotetext{
77 "Death Wish: Russia Appears to Be Committing Suicide," The Economist, October 2, 2004, p. 50.
} 
Russia census in October 2002 estimated. $^{78}$ Lower birth rates, ageing workforce, and shorter life expectancy are taking their toll on the country.

Millions of Russia's citizens are "trapped" in their constituencies. Those who migrate prefer to relocate to regional centers or to Moscow, where economic conditions for employment are more favorable than in the rest of Russia. ${ }^{79}$ Lack of incentives to stay in provinces is leaving much of rural Russia deserted and drives urbanization. Dissolution of the system of collective farms (kolkhozy) has virtually paralyzed the agricultural sector of the economy, and abandoned villages leave large plots of land unpopulated and unutilized. Formerly state-subsidized small and medium-size towns decline and disappear from maps. Larger cities, even those built in very cold and remote places, still hold primarily because the subsidies are still in place.

\section{Depopulation of Siberia and the Far East and the Drift Westward}

The processes of depopulation, limited migration and urbanization have important implications for the federation and its constituencies. On the security agenda there is the possibility of Chinese expansion to the depopulated areas of the Far East. The issue has

\footnotetext{
${ }^{78}$ GosKomStat estimates that Russia loses as much as $0,5 \%$ of its population per year despite increase of migration from Central Asia and the Caucasus and strong economic growth. See "Informatsiya of Sotsial'no-Ekonomicheskom Polozhenii Rossii-2005" (Information on Socioeconomic Conditions of Russia in 2005), "Section VII: Demographics," GosKomStat, online at www.gks.ru/bdg/free/b05 00//swPrx.dll/Stg/d010/i010180r.htm

${ }^{79}$ According to GosKomStat, regional migration to Moscow has been positive throughout the last decade and stands at about 50000 people in 2003. Saint Petersburg demonstrates a much more modest inflow of people. See "Russian Federation Statistical Appendix," IMF Country Report No. 04/315, International Monetary Fund, Washington, DC, September 2004.
} 
been exaggerated and has raised major concerns. ${ }^{80}$ There is some migration from China manifested in the Chinese farmers resettling the otherwise vacated and stagnant villages of Primorskii Krai. ${ }^{81}$ Other Russian regions, like KPAO, Karelia, and Komi, have also been heavily stricken with the demographic crisis. The federal and regional government has so far been unsuccessful in countering it.

The government lacks the repressive apparatus and the ideology, so the spatial depopulation can no longer be addressed with raspredelenie. Moreover, the government is reluctant to offer economic incentives for relocating people from stagnant regions. Instead, it is doomed to sustain the ageing immobile population in places of their current residence. However, since it is extremely expensive to maintain life-supporting infrastructure in the North and the East, the federal government has introduced relocation programs. These programs designed to move people from the North to Central Russia have been funded since early 1990 s, but remain limited in their scope. ${ }^{82}$ If the programs succeed, the state would be challenged with another problem - governance of depopulated areas. It is a common belief that, if left ungoverned, the territories would be resettled by foreigners and that this would eventually lead to loss of some of the Eastern territories. Elsewhere in Russia, particularly in the North, depopulation is rapidly becoming an issue of efficient governance. The question of whether depopulated territories are worth being governed as separate constituencies with federal representation remains unanswered.

\footnotetext{
${ }^{80}$ See, for example, Marina Grekhova and Denis Chuprov, “Malen'kii Kitai”' (Small China), Expert-Sibir', No. 33 (47), November 8,2004 .

${ }^{81}$ See, for example, James Brooke, "New Face of Farming in the Russia's Far East. Rich Land Draws Reverse Migration," The New York Times, July 8, 2004, p. W 1.

${ }^{82}$ See Expert, No 26, July 12-18, 2004, p. 68-73.
} 
In the following paragraphs I overview recent changes in the demographics of the three matryoshkas proposed for enlargement. All three cases fit into the general demographic trends of the post-Soviet Russia.

\section{Perm Matryoshka}

The population of Perm' Oblast', including KPAO, decreased from 3,100,000 people in 1989 to $2,819,421$ in 2002 . The change in population has been different throughout the region. While the population of the region has decreased by over a quarter of a million people, the population of the City of Perm' has only shrunk by some 89,000 . An even greater contrast is obvious in comparison of Perm' and KPAO. Between censuses of 1989 and 2002, the population of KPAO has decreased by 14.2 percent, while the population of Perm' Oblast' only shrunk by 7 percent. ${ }^{83}$ Migration from other regions of Russia has been insufficient to replenish the numbers lost to the demographic crisis. Migration increase between 1991 and 2000 has been estimated at +7.3 percent people for Perm', and -4.5 percent for KPAO. ${ }^{84}$ Migration from the Commonwealth of Independent States (CIS) is a fairly recent phenomenon in the region. The overwhelming majority of foreign labor migrants work in Perm' and other cities of the Oblast'. Rural areas and KPAO are unattractive destinations for them.

\footnotetext{
${ }^{83}$ Yekaterina Dobrynina, "V Osobo Krupnykh Razmerah. Sliyanie Regionov Nachali s Permskoi Oblasti. Problemy Vperedi” (In Very Large Quantity. Merger of Regions is Started in Perm' Oblast'. Problems Lie Ahead), Rossiiskaya Gazeta, March 6, 2004. Online at www.rg.ru/2004/03/26/perm.html

${ }^{84}$ Migratsionnaya Situatsiya v Regionah Rossii. Vipusk 1: Privolzhskii Federal'nyi Okrug (Migration Situation in Russia's Regions. Issue I: Volga Federal District), S. Arboletovskii and Zh. Zaionchkovskaya (Eds.), Moscow, 2004, p. $52-53$
} 


\section{Irkutsk Matryoshka}

All Far Eastern and Eastern Siberian regions are net donors of population as a result of the Westward population drift. The Eastern "giving zone" stretches from Kamchatka to Krasnoyarsk and constitutes 60 percent of Russia's landmass while accounting for only 10 percent of the population. According to Demoscope Weekly, a Russian demography magazine of the Academy of Sciences, net migration from Irkutsk Oblast' amounted to 11.5 percent between 2001 and $2003 .^{85}$ The figure would have been higher had Irkutsk been situated further to the East. Located in the center of Siberia, it collects migrants from most of the constituencies to the East of it. Many migrants don't stay in Irkutsk, and continue their movement westwards to Krasnoyarsk Krai, Tyumen' Oblast', and over the Urals to European Russia. Over the last decade, it has been able to compensate only half of its population loss. U-OBAO has also been losing population. Its deteriorating agricultural economy is not attractive for migrants, and, in any case, can hardly sustain growing population. Thus, the population is gradually declining in both regions.

\section{Tyumen' Matryoshka}

Unlike Perm' and Irkutsk regions, Tyumen', KhMAO, and YaNAO remained sparsely populated outposts of the Russian Empire (Tobol'sk) and homes to indigenous ethnicities of the North until after the introduction of autonomization policy in 1930s.

\footnotetext{
${ }^{85}$ The figure includes transit migration from other regions to the East of Irkutsk. "Migratsia v Rossii: Zapadnyi Dreif" (Migration in Russia: The Drift Westwards), Demoscope Weekly, N 185-186, January 10-23, 2005. Online at www.demoscope.ru/center/rass/rassylkal $85 . \mathrm{html}$
} 
Growth of Western Siberian cities didn't take off until significant oil and gas deposits were discovered in the1960s. The oil towns grew extensively throughout the 1970s and 1980s, but their population growth has dwindled after all major oil and gas field had been tapped. The areas have once again become attractive for migration in the recent years. In 2003 alone, high salaries have attracted 6, 097 people to KhMAO, 427 to YaNAO, and 4,457 to Tyumen' ${ }^{86}$ Although much of migration is seasonal or bears a "transit" or "flushing" character ${ }^{87}$ and the local population is plagued by low birth rates and drug abuse, the region currently demonstrates a net population increase. As a result of collectivization, industrialization, and poor environmental conditions, traditional nomadic lifestyles of indigenous peoples of Western Siberia have been disrupted. The indigenous (titular) population of deer on which they subsist has declined, and so have their own numbers.

\section{MERGERS OF REGIONS AS MERGERS OF CITIES}

Like houses in Russia that are often only Potemkin facades, regions are also only colored areas on Russia's administrative map. Russia's space is extremely localized and is very uneven. "What is painted in one color on the map and is called "the subject of the Federation," in reality represents city No 1 and city No $2 . " 88$ These localities and the difference among them may be unnoticeable as a result of regional statistical estimation. However, they drastically differ in their development and by a number of other parameters.

\footnotetext{
${ }^{86}$ MERT data. As cited in Expert No 26, July 12-18, 2004, at p. 71.

${ }^{87}$ Thousands of people travel to Western Siberia to earn money, and then return to European Russia. Yet thousands transit through the area en route from Eastern Siberia and the Far East.

${ }^{88}$ Vyacheslav Glazychev, "Kapitalizatsiya Prostranstva" (Capitalization of Space), Expert, No 1, January 12-18, 2004, p. 100-104, at p. 101 .
} 
Over the last fifteen years, population distribution has become increasingly skewed towards larger cities, particularly Moscow, and some regional capitals. An urbanized state, especially a monocentric one like Russia, may prove easier to govern. The level of urbanization in regions and concentration of population in regional capitals is particularly high in a number of Russia's Northern and Eastern constituencies, including Perm', Yekaterinburg, Tyumen', Krasnoyarsk, and Irkutsk. In fact, the oversized Northern cities like Perm' and Irkutsk account for as much as a third of regional population. Russian regional capitals, shaped by planned economy and the size of the Soviet military-industrial complex $(V P K)$, often combine the roles of political, educational, cultural, financial, and manufacturing centers in their regions.

The uneven concentration of human resources and financial capital in regional centers can be advantageous for the federal and regional governments. This advantage can be reduced to a simple formula: Those who control the regional capital, control the region (See Table 5, p. 180). If the state (or regional government) wants to be successful in pursuit of their agenda, like the enlargement of regions, the control of regions' capital city may prove significant enough to gain political and financial support in order to swing the vote in favor of their plan or candidate. It appears to be even easier to accomplish since the introduction of the new system of appointment of governors and substitution of position of elected city mayors with appointed city managers in some regional centers. Thus, the task of the proponents of merger is spatially simplified. It may be enough to control and merge regional capitals to merge the regions. 


\section{Perm' Matryoshka}

There are a total of eight cities in Perm' Oblast' with a population of 50,000 or more. The single city in KPAO is its capital Kudymkar with 31,914 people. Perm' Oblast's urban population currently stands at 73.9 percent, and KPAO's at 26.3 (See Table 5, p. 180). The settlement pattern creates favorable conditions for conducting referendums in Perm'. Conditions are less favorable in KPAO. With half of the oblast's population and capital concentrated in three cities - Perm', Berezniki, and Solikamsk, regional enlargement campaigns could be, and were, largely limited to these three cities. Given that larger cities are initially quite autonomous within their regions, their electorates would not be much concerned if their region merges with the neighboring okrug or not. In fact, most of the population never even suspected that KPAO had been an independent subject of the federation throughout the 1990s. Since the impact of merger on these constituencies appears to be minimal, and given the large scale of the enlargement campaigns in these localities, the positive result of the pilot project of regional enlargement had been guaranteed. The support of the merger had been overwhelming in both constituencies.

The merger of Perm' and KPAO may not yield significant economic benefits for the larger region. However, it will definitely help the newly formed Permskii Krai to slightly increase its population. In 2002, officials in the City of Perm' had to incorporate neighboring satellite towns and villages into Perm' to maintain the status of a 
"millionaire city" (city with a population of over one million). Upon merger, the population of the merged region would amount to 2,819,421 people. However insignificant, the additional 136,076 would reinforce the region's position as fifteenth in Russia by population. Municipal reforms and labor migration from Central Asia and the Caucasus may maintain Perm's millionaire status at least until the next census.

\section{Irkutsk Matryoshka}

The formula that the control of the largest city entails the control of the region is not applicable to Irkutsk and U-OBAO. There are seven cities of over 50, 000 in Irkutsk Oblast'. However, unlike Perm', the regional capital is smaller, accounting for 24.3 percent of the population. U-OBAO is entirely rural. Its capital, Ust'-Ordynskii with a population of 13,200 has no city status. Both territories are hard to control because of the even population distribution among the urban areas in Irkutsk Oblast' and deconcentration of rural population in U-OBAO. With the absence of a single major center, a referendum on regional enlargement is unlikely to yield numbers similar to Perm' in terms of both participation and support for enlargement. While Irkutsk is a large capital city of 593,604 people, alternative centers exist in the region:Angarsk and Bratsk are both half the size of Irkutsk. The total urban population of Irkutsk Oblast' is 83.7 percent. 
The demographic crisis has had a different impact across ethnicities. The population of the ethnic republics in the South continued to increase after the breakup of the USSR despite war in Chechnya and widespread political and economic instability. Population of Ethnic Russians, which constitute over 85 percent of total Russia's population, as opposed to about 50 percent in the USSR, decreases. Small indigenous peoples, residing in autonomous okrugs, have experienced one of the greatest net population losses in the short-term. Historically small in number, even a minute loss of population can prove disastrous for their communities.

Studying Soviet federalism, Philip Roeder references the abolition of the KareloFinnish Republic. He predicts "demotion to the status of an autonomous republic" should it fail to maintain "titular nationality's numerical predominance within a republic and allow the replacement of the ethnically exclusive cadre by one of more diverse ethnic composition. ${ }^{89}$ Similarly, the enlargement of regions in modern Russia may prove politically tragic to some of Russia's indigenous peoples. The federal government tends to put the issue of ethnic self-determination of small ethnic groups secondary to the landmass and population (and economy) of their autonomous okrugs. The overall neglect of nationalities issues in Russia was demonstrated by the abolition of the Nationalities Ministry in March 2004 with its functions of regional economic development transferred to the Ministry of Economic Development and Trade (MERT). It was reinstated in the aftermath of Beslan as the Ministry of Regional Development. ${ }^{90}$

\footnotetext{
${ }^{89}$ Roeder, 1991, p. 224

${ }^{90}$ Some functions of regional economic planning and execution of regional development programs are still retained by MERT.
} 
Mergers of regions are diluting national and cultural autonomy of Russia. I would not argue the respective cultures of the small Northern (indigenous) peoples of KomiPermyaks, Khanty, Mansi, and Nenets would be suppressed in any way. On the opposite, mergers may give them additional economic security and even insignificantly enhance their socioeconomic standing. However, the proportional "weight" of their votes in regional legislatures would decrease along with their overall representation (See Table 3 and 3-A, p. 177 and 178). The cultural uniqueness of indigenous ethnicities of the AOs will be erased from the political map of the Russian Federation as a result of regional mergers. Thus, the federative principle of unity in diversity will assume a simpler form. For the time being, the titular ethnicities of the ethnic republics will retain a degree of autonomy in Russia, while titular ethnicities of the autonomous okrugs would become politically marginalized. Thus, the principle of unity in diversity will be partially sacrificed for the purposes of creating a more horizontally symmetric federative state.

\section{Perm' Matryoshka}

According to the 2002 Census data, KPAO's titular ethnicity (Komi-Permyak) constituted 59 percent of the population. Russians, the second largest ethnicity constituted 38 percent. Perm' Oblast' is predominantly Russian ( 87.6 percent) with some presence of titular ethnicities of the nearby ethnic republics (See Table 3 and 3-A, p. 177 and 178). 
Despite the ethnic character of KPAO's status as a subject of the Federation, the ethnic factor seemingly played an insignificant role in the enlargement process. A decade of economic and political crisis has left the region desperate for investment and growth. According to federal and regional officials, merger with Perm' Oblast' is projected to increase the socioeconomic well being of KPAO and the enlarged region as a whole. The Komi-Permyak majority (59 percent) is being diluted in the Russian majority of the enlarged Permskii Krai. Being the largest ethnicity in the small autonomous okrug, Komi-Permyaks are now the third largest ethnicity in the region - after Russians with 85 percent and Tatars with 4.9 percent. Since the merger of Perm' and KPAO was implemented as a pilot project, other poor autonomous okrugs may soon follow.

\section{Irkutsk Matryoshka}

In terms of population, U-OBAO is somewhat similar to KPAO. However, its ethnic mix is different. A sizeable population of ethnic Buriats makes up the second largest ethnic group after Russians - 39.6 and 54.4 percent respectively (See Table 3 and 3-A, p. 177 and 178). Upon the disintegration of the USSR, Buriat people were among the first to express their resolve to pursue greater autonomy and independence. Moreover, they intended to create a single Buriat autonomy (state) by uniting the three ethnic Buriat constituencies - U-OBAO, Aginskii Byruatskii AO, and the Republic of Buriatia. If implemented, incorporation of U-OBAO into Irkutsk' Oblast' would handicap the Buriat ambition to unite, and would probably make it outright impossible in the near future. 


\section{Tyumen Matryoshka}

KhMAO and YaNAO are official homes to the indigenous (titular) groups of Khanty, and Mansi (KhMAO), and Nenets (YaNAO). Unlike titular ethnic groups of $\mathrm{KPAO}$ and U-OBAO, these groups are underrepresented in their constituencies prior to enlargement. (See Table 3 and 3-A, p. 177 and 178). In KhMAO, Khanty is only seventh largest ethnicity with less than 1 percent of the total population; Mansi is ninth largest ethnic group and is on the verge of disappearance. Their total population in the enlarged region is only 10,561 , while Khanty population is larger and stands at 26,694 . Nenets has a relatively large population of 5.2 percent in YaNAO, and is the fourth largest group. Also, Nenets have sizeable populations in the neighboring regions, particularly in Dolgano-Nenetskii and in Nenetskii Autonomous Okrugs. However, in the enlarged region it becomes a marginal ninth largest group.

Enlargement of regions would have no significant impact on ethnic minorities of Khanty and Mansi, but it will on the ethnic Nenets. They, like Buriats in Eastern Siberia, would have to give up their aspirations for a unified Nenets region. Dolgano-Nenetskii AO has already merged with Krasnoyarsk Krai, and Nenetskii AO may merge with Archangel'sk Oblast'. As in the case of Buriats, regional merger will effectively prevent the aspirations of the indigenous peoples for a unified ethnic homeland.

\section{ROLE OF DEMOGRAPHIC FACTOR IN THE ENLARGEMENT OF REGIONS}


The Russian population is unevenly distributed across its vast space. The creation of fewer regions through merger is grounded in the argument that regions should be governed in an expedient manner. By this logic, sparsely populated areas should not have federal status of representation in the federal legislature regardless of their economy and landmass (See Table 4, p. 179). As it is clear from the table, more densely populated constituencies (Perm') have fewer representatives in legislature per capita, but more representatives per square kilometer. Ratios change with the change in population density and in area of a constituency. However, population of Russia is not only unequally distributed among constituencies. Almost always it is concentrated in particular areas within them. Thus, representation at the regional level may in fact reflect the actual needs of a constituency and be balanced and proportionate. At the federal level constituencies are not necessarily represented because of their population or area size. Often their status is a result of historical processes and the right of self-determination and autonomy previously granted to ethnic minorities in the RSFSR.

The demographic situation in the merged regions and in those proposed for enlargement is quite different. While all constituencies have experienced a demographic crisis since the breakup of the USSR, Eastern regions (Irkutsk) are the hardest hit. Population is somewhat sustained by in-migration. Regional enlargement may significantly increase the region's territory and population in the case of Tyumen' matryoshka. In fact, its merger would create one of the largest regions of Russia in terms of population, as well as landmass and per capita income. In two other cases - Perm' and 
$\mathrm{KPAO}$ and Irkutsk and U-OBAO, regional population and area increase only marginally. However, even a small increase may sustain the size of populations until next census. ${ }^{91}$

The efficient governance argument may be a strong justification for merger of Perm' Oblast' and KPAO. KPAO is a sparsely populated and small subject of the federation. However, the argument may prove strongest for Irkutsk, because of the fact that U-OBAO is an even smaller and all-rural constituency. If KPAO had borders with three regions, including Perm' Oblast', U-OBAO is landlocked within Irkutsk Oblast'.

The federal and regional government can capitalize on spatial concentration of people in Perm' and, possibly, Tyumen' Oblasts. However, population is more evenly distributed across Irkutsk and U-OBAO, where both constituencies lack a single center of regional power. Possibly, the skewed distribution of population in Perm' and KPAO has allowed the federal and regional governments to manipulate the constituencies more effectively and cheaply. The spatial distribution of population has helped the authorities to test the policy of the enlargement of regions in Perm' and KPAO.

Ethnic Russians constitute a numeric majority in at least half of Russia's ethnic republics. All three cases of the enlargement of regions appear to solidify the numeric supremacy of ethnic Russians in the autonomous okrugs as titular ethnicities get diluted. While in the enlarged Permskii Krai Komi-Permyaks will still retain the status of a fairly large (third largest) ethnicity, their share in the population will decrease from 59 percent in KPAO to only 3.7 in the Krai. Thus, within Permskii Krai, Komi-Permyaks will

\footnotetext{
${ }^{91}$ Population of oblast ' (or krai) in $2002=$ population of oblast' $($ or krai) + population of okrug in the next census.
} 
become what Valery Tishkov defines as a "double minority," or a minority at both the federal and the regional level. ${ }^{92}$ Moreover, Komi-Permyaks will have no subject of the Federation of their own elsewhere in Russia. The only one they had would be merged with Perm' Oblast'.

I have estimated the proportion of ethnic Buriats to drop from 39.6 percent in UOBAO to 3.1 in the enlarged Irkutsk' region. Moreover, merger of Irkutsk and U-OBAO would make the idea of Buriat unity in the Russian Federation an impossible task in the foreseeable future.

The issue of dilution of titular ethnicities is least acute in Tyumen', KhMAO, and YaNAO. Already marginalized indigenous populations would continue to lose their political power despite the existence of special arrangements between them and the regional and federal governments.

Mergers of Perm' and KPAO and Irkutsk and U-OBAO seems justified from the standpoint of horizontal federal symmetry. Merger of Tyumen', KhMAO and YaNAO may create an oversized and economically strong region. ${ }^{93}$ Despite the relatively low population density and the spatial character of its development, appearance of a merged region of such scale in Russia can hardly be attributed to the state's goal to rearrange Russian internal borders in a more consistent symmetrical way.

\footnotetext{
${ }^{92}$ For a detailed study of the concept of double minorities, see Valery Tishkov, Ethnicity, Nationalism, and Conflict in and After the Soviet Union: The Mind Aflame, London, Sage, 1997, at p. 241.

${ }^{93}$ Tyumen's population after merger would be $3,264,841$ people. Over half of Russia's constituencies now have a population of 800-900 000 people. In Aleksandr Potemkin, “Men'she Regionov - Sil'nee Strana" (Fewer Regions Stronger State), Rossiiskaya Gazeta, December 8, 2004. Online at www.rg.ru/2004/12/08/regiony.html
} 
I suggest that, if regions merge in all the three cases, the Russian Federation would demonstrate its disregard for the right of small indigenous populations to selfdetermination. The federal principle of unity in diversity would be undermined, because the titular ethnicities of the autonomous okrugs would lose the limited access to political power they were able to enjoy in the RSFSR and in the fifteen years following the signing of the Federative Treaty. Political clout would no longer complement their cultural uniqueness and autonomy. This trend signifies change of emphasis in the Russian federal division from ethno-federalism to administrative-territorial federalism. 


\section{CHAPTER III. POLITICS OF REGIONAL ENLARGEMENT}

The principles of the 1993 Constitution provide for Russia's status as a federated state, and guarantee its ethnic constituencies the right to self-determination short of secession. Therefore, the state's supreme law stipulates a democratic principle of "unity in diversity" in the Federation. By guaranteeing "equal" status and representation to all of its asymmetric constituencies, the weak central state created an extremely asymmetrical federative political system in the 1990s. The system, created to prevent Russia from disintegration, was designed unsustainable for normal development of the state. The federation needed to be rebuilt. This asymmetry was exacerbated by the war in Chechnya, which put large parts of the Southern Federal District under federal military rule and brought chaos to the political and economic life of the region. Together with the economic "baggage" of RSFSR's planned economy, unbalanced fiscal and budgetary relations between center and periphery, and widespread corruption, the system lacked minimal cohesion and order.

The asymmetric nature of regions reemerged on the state agenda upon the recovery from the default of the summer of 1998. The strengthening state required change in the existing system of federative relations, in which a number of regions enjoyed vast authority and had multiple benefits but few obligations. 
Russia's federal government failed to resolve the issue of separatism in the North Caucasus by force. Despite introduction of federal districts and polpreds, it also failed to effectively contain regional power of ethnic republics and economically strong regions by peaceful means of renegotiating their power-sharing treaties. Reinstatement of the supremacy of the Russian Constitution was finally achieved during the first few years of Putin's presidency. However, this development alone was clearly not enough to maintain the integrity of the federation and the authority of the federal government. Therefore, the components of gosudarstvennost' and the rule of law were insufficient to build a strong state that the government had envisioned. Multiple territorial challenges to governing Russia persisted.

The system formed under Yeltsin proved to be a rather effective temporary construct to absorb the shocks of the breakup of the Soviet empire. The threats of further disintegration in the 1990s were countered with decentralization. However, it is also the external security that keeps federations together and strengthens them. Russian security dilemma is neither strictly internal nor external. The threats are of a peripheral nature. They originate in the spread of militant Islamic ideologies from the South, the ongoing instability in the Caucasus, and the inability of the federal enter to control remote regions.

The federal government will have more power within a more homogeneous and symmetrical federation. ${ }^{94}$ I suggest that, with that in mind, Putin and his associates have planned to opt for more symmetry to replace the existing disorder. Thus, the move from

\footnotetext{
${ }^{94}$ Watts, 1996, p. 31
} 
creating symmetry by drawing federal districts is evolving towards the enhancement of symmetry within federal districts and across the Federation.

Since complete redrawing of borders would have put the system under great and unnecessary stress and fueled a new wave of secessionism by ethnic republics, the government has decided to approach the problem of symmetry from the other end. It has chosen to deal with existing regions by merging the smaller with the bigger and the poorer with the richer. ${ }^{95}$ The enlargement of regions appears to be the easiest solution to Russia's governance dilemma, and, possibly, as a shortcut to establishment of a more symmetrical federation.

\section{PERMSKII KRAI AS A PILOT PROJECT OF REGIONAL ENLARGEMENT}

Lands around Perm' (Perm' Velikaya), which included the present Perm' Oblast' and Komi-Permyatskii Autonomous Okrug (KPAO), were officially incorporated in Russia in 1478. KPAO was formed as a national okrug on February 26, 1925, to become the first national okrug established in the young Soviet Russia. In 1977 its status was nominally changed to autonomous okrug, and in 1993 it became an independent (from Perm' Oblast') subject of the Federation. The December 72003 referendum reunited KPAO with Perm' Oblast' by merging the two subjects of the Federation and the formation of Permskii Krai ${ }^{96}$ Thus, KPAO became Russia's first autonomous okrug in terms of both attainment and cession of its status (See Table 2, p. 176).

\footnotetext{
${ }_{95}$ At present, ethnic republics are not negotiating enlargement.

${ }^{96}$ Andrei Brazhitsa, "History of Komi-Permyatskii Okrug," online at www.gazeta.ru
} 
The initial proponents of the idea of merger of Perm' and KPAO are impossible to identify. Although concepts of redrawing Russia's internal borders have been disputed since the rise of nationalist tensions in late USSR, they never specified the methods or sequence of restructuring. Possibly, the idea to single out Perm' and KPAO as a testing ground and merge them through referendum originated somewhere in the federal government. In this and subsequent chapters I examine the enlargement process in terms of its top-down or bottom-up character. After all, the new law on local self-governance devised by Kozak makes provisions for abolition of autonomous okrugs as federal units. At the same time, enlargement can ultimately take place only if approved through regional referendums in the merging regions.

A curious aspect of regional enlargements is the federal government's official "hands-off" policy. ${ }^{97}$ President Putin, the Chairman of VTSIK Aleksandr Veshnyakov, and other top-level state officials have constantly emphasized that the enlargement of regions is a bottom-up political process. They allege that, although the regional governments might initiate it, the ultimate decision is the expression of the will of the populations of the respective constituencies. However, federal involvement is obvious, especially in the initial steps towards merger.

Upon the establishment of federal districts, President Putin revived the discussion of restructuring Russia's federal-regional relations and the regional enlargement. $\mathrm{He}$

\footnotetext{
${ }^{97}$ See, for example, In the Spotlight, October 31, 2003, online at www.kremlin.ru/eng/text/themes/2003/10/312052_54807.shtml President Putin contends "there should be noting forced about this (enlargement) process."
} 
urged the strong regions to support the poor and heavily subsidized regions. Federal initiatives began to materialize at the regional level with the signing of the Agreement on Realization of Priority Trends in the Treaty on Relations between the Governing Bodies of Perm' Oblast' and KPAO in $2002 .^{98}$ This document triggered the setting up of a trimember administrative work group consisting of federal bureaucrats and representatives of the two constituencies for working out the expediency of merger. The group also prepared legislation for merger. Subsequently, a civil coordination council, chaired by a Federation Councilman's deputy Ivan Chetin, was created to determine the status of KPAO in the merged region. Later, on June 262003 , enlargement was supported by a unanimous vote at the meeting of representatives of all levels of KPAO. The federal government did not hesitate to start merging its representative bodies of the two regions before referendums were conducted in the regions. The last important step of the preparation for the enlargement was the visit of Vladimir Putin. The president made stops in regional capitals of Perm' and Kudymkar, met with regional leaders, and promised an extensive federal aid program.

The federal government paid close attention to the merger with President's aide Vladislav Surkov appointed to supervise the process. The federal center had to ensure that the referendum would go smoothly and yield a desired result: set the precedent of regional enlargement through merger of an autonomous okrug with a "parent region.",99 The referendum on enlargement was thoughtfully scheduled to coincide with the State

\footnotetext{
98 "Soglashenie o Realizatsii Prioritetnykh Napravlenii Dogovora ob Otnosheniah mezhdy Ogranami Gosudarstvennoi Vlasti Permskoi Oblasti I KPAO na 2002 god," author's personal copy.

${ }^{99}$ In May 2003, Validate Sociological Services conducted preliminary opinion polls in all KPAO's districts and concluded that as many as 68 percent of the voters would support the enlargement.
} 
Duma elections on December 7, 2003. This ensured a higher turnout of over $60 \%$ in Perm' and 70 percent in KPAO. The results were impressive. In Perm'Oblast' as many as 84 percent of the voters supported the merger. In KPAO this figure stood at an impressive 90 percent of the voters. ${ }^{100}$

There are various reasons why Perm' and KPAO were chosen as a pilot projects of regional enlargement by the federal government. The primary reason was the confidence in successful outcome. Indeed, a great number of local, regional, and federal resources were pulled together to ensure the "yes" vote.

One of the most favorable conditions was the close and fruitful cooperation of regional elites with each other and the federal government. Both governors were ready to "sacrifice" their posts for the enlargement project as they would have lost their positions upon completion of merger. A new governor of the enlarged region would then be elected (rather, according to the new law, his candidacy would be proposed by the president and approved by regional legislative body).

The support of the enlargement in Perm' Oblast' was largely the result of its governor's efforts. Indeed, Governor Yuri Trutnev was a charismatic figure in Perm' politics, and retains influence to this day. ${ }^{101}$ Voters believed that if the governor advocates for the merger, it must bring positive change, particularly in the economic

\footnotetext{
${ }^{100}$ Starting in 2006, Russian federal elections, regional elections, and referendums will only be conducted in October, December, and March. The new law, passed in the Duma in May 2005, is aimed at cutting electoral campaign expenditures. I argue that "synchronization" of elections would implicitly increase turnout fight and fight voter apathy. Elections results available online at www.regnum.ru

${ }^{101}$ Upon the successful completion of the merger, he was appointed the Minister of Natural Resources of Russia in March 2004, the only former governor in the top echelon of the executive branch of Putin's government.
} 
sphere. Curiously enough, seems like many voters in Perm' didn't realize that KPAO had been an independent subject of the federation for over a decade, and, therefore adopted the governor's position with ease.

In 2002, KPAO's governor Gennady Saveliev was elected on the promise to mediate merger of Perm' and KPAO. However, the actual economic benefits that the merger was to entail were never articulated. Still, the positive outcome of voting in KPAO was grounded in the hopes for the better economic future. The hopes of the electorate were especially high in the aftermath of Putin's visit to the capitals of the merging constituencies one month prior to the referendum. The economic arrangements and the incentives from the federal center are discussed in the next chapter.

The national (ethnic) aspect of the enlargement was also addressed. On October 30, 2003, seventeen national organizations of Perm' and KPAO circulated a joint statement urging citizens to take part in the enlargement referendum. Community leaders of regional ethnic groups, including Komi-Permyaks, stressed the multiethnic character of Perm' and KPAO. They described the regions as "united by a common ethno-cultural space, where the greatest resources to be preserved and multiplied were peace and concord, friendship and mutual understanding." 102 In addition, thirty-two initiative groups were formed to campaign for the enlargement. ${ }^{103}$

\footnotetext{
${ }^{102}$ Posted online by the Regnum News Agency www.regnum.ru/news/174113.html Also available at www.krai.perm.ru 103 "Storonniki Permskogo Krays Sozdali 32 Initsiativnye Gruppy" (Supporters of Permskii Krai Have Formed 32 Initiative Groups), Regnum News Agency, October 30, 2004. Online at www.regnum.ru/news/174113.html
} 
First of all, governors of merging regions lose their posts and are succeeded by one new (appointed) governor. It is yet unclear how the new legislature of the Perm Krai will be formed. According to the legislation developed at the time of the referendum, a new governor of the merged region was to be elected in December 2005. Legislative bodies of the enlarged regions were to be restructured after the elections for governor. According to the new system of appointment of governors, a candidacy submitted by the president should be approved by the regional legislature. If the new legislature shall not be formed by December, the new governor would be elected. This would make the governor of Permskii Krai the last elected governor of a Russian region. ${ }^{107}$

The second major governance challenge is the formation of a new legislative body. Given the size of the current KPAO legislature and the location of the capital in the City of Perm', it is more accurate to consider the merger of legislatures an acquisition of the KPAO body by Perm'. (See Table 4, p. 179). While Perm' Oblast's regional legislature consisted of 40 representatives before merger, KPAO's only had 15 . In sum, the total number of representatives in the new legislature would equal 55. However, the official laws governing the new legislature stipulate 60 representatives, while the currently acting legislatures are fighting to raise this number to $80 .{ }^{108}$ In addition to the regional legislature, KPAO shall retain its own municipal legislature (Duma) consisting of 20 members. Thus, the enlargement will add up to 40 new representatives on both Krai and former KPAO levels.

\footnotetext{
${ }^{107}$ The last governor was elected by direct popular vote in YaNAO in January 2005.

${ }^{108}$ It is unclear if a certain number of seats would be reserved for the indigenous Komi-Permyaks.
} 
According to the ratio of number of people per legislative official and square kilometers per legislative official, the elimination of KPAO may be somewhat expedient. However, like elsewhere in Russia, the administrative reform is not decreasing the size of bureaucratic apparatus. On the opposite, the number of officials per capita will increase in the larger region (at least compared to Perm' Oblast'). The same ratio would decrease for KPAO as it becomes a constituent part of Permskii Krai. However, the autonomous okrug will lose its status as a subject of the federation; its power to dissolve in the greater Perm' politics. Thus, it is likely to be marginalized even further. According to Kozak's Reform, Perm' Oblast' is being redistricted into 294 municipalities. ${ }^{109}$ KPAO will become the $295^{\text {th }}$ municipality of the merged region. In addition, KPAO, as a municipal administrative-territorial entity will be subdivided into smaller municipalities Kudymkar, and other. Thus, between the merger referendum on December 7, 2003 and the date of merger of Perm' Oblast' and KPAO on December 1, 2005, KPAO undergoes a transition from being one of eighty-nine subjects of the Russian Federation with federal representation to one in at least 295 municipalities of Permskii Krai with no direct federal representation and marginal representation at the regional level.

To summarize the political aspect of the formation of Permskii Krai, there are two major sets of issues to be addressed - conditions for successful enlargement, and its objectives and outcomes.

\footnotetext{
${ }^{109}$ Ol'ga Deriagina, "Ne Lezt' na Rozhon" (Don't Ask for Trouble), Novyi Kompan 'ion-Perm', No 20 (361), June 15, 2005.
} 
There are three conditions that appear vital to successful enlargement. First and foremost, the displays of mutual resolve for enlargement by executive and legislative branches of merging regions are important. Political willingness is enhanced if supplemented with cohesive initiatives for enlargement. Second, the federal government's support of merger by passing relevant orders and adopting laws as well as provision of incentives is essential. Mergers of regions are impossible without federal support. Third, thorough organization of referendum campaigns is helpful. Regional and federal authorities tend to seek support from a wide array of political and social groups from Orthodox Church - to business unions - to civil organizations based on ethnicity, culture, profession, or territory. To ensure sufficient turnout, it is preferable that a referendum on enlargement coincides with local, regional, or federal elections. ${ }^{110}$ The enlargement in Perm' was successful because all three conditions were meticulously observed.

There are two direct and two indirect outcomes to the referendum in Perm' and KPAO. First, enlargement enhances horizontal symmetry of the state by merging smaller "unviable" units with larger and economically sound neighbors. Thus, at least in the case of Perm', enlargement is a process of acquisition of a small region by a larger region, rather than a merger of equals. Second, enlargement not only enhances symmetry on the federal level, but also at the level of federal districts. In the Volga FD it balances Oblasts (Perm', Samara, Nizhny Novgorod) among themselves and with the strongest of Russia's ethnic Republics of Tatarstan and Bashkortostan. The ethnic Russian-dominated

\footnotetext{
${ }^{110}$ By federal law, 50 percent of eligible voters should vote in a referendum to validate its results. Similar legislation is exists at the regional level.
} 
industrial Oblasts become more equal in their size and population. Thus, political competition is fostered and balance is reached. Disappearance of an ethnically-defined, albeit small, region from the composition of the Volga FD may give more bargaining power to its polpred Sergey Kirienko. It may enable him to mount additional pressure on the increasingly estranged ethnic republics.

The two indirect outcomes deal with the balance among the federal districts and the federal bargaining power vis-à-vis ethnic republics. First, enlargement affects neighboring ethnically defined republics and oblasts with ethnic Russian majority. Despite traditional political and economic ties between Perm' Oblast' and KPAO, hypothetically, the latter could have gravitated closer to the ethnic Republic of Komi in the Northwest. Although Komi and Komi-Permyaks are different ethnicities, they do share common Finno-Ugric ethnic and cultural roots. The state does not appear to favor redrawing division into federal districts in favor of titular ethnicities. In order to dissolve KPAO, it was first placed in the Volga FD, while Komi Republic was placed in the Northwestern. The merger of Perm' Oblast' and KPAO and the formation of Permskii Krai has solidified the artificial border between Volga and Northwest. Perm' Oblast' itself geographically falls into two FDs - Ural and Volga. It was included in Volga FD to finally kill the ambitions of Yekaterinburg governor Eduard Rossel' to form the Ural Republic - a union of geographically linked industrial Sverdlovsk (Yekaterinburg), Chelyabinsk, and Kurgan Oblasts. ${ }^{111}$

\footnotetext{
111 See, for example, "Sverdlovskii Gubernator Otryoksa ot Ural'skoi Respubliki" (Sverdlovsk Governor has Renounced Ural Republic), Kommersant, April 28, 2004. Note that regions with status of "Republics" are all ethnicitybased. Had Rossel' succeeded, the formation of the Ural Republic would have set a precedent of forming majority ethnic Russian Republics. This would have taken separatism to a new level and threatened the unity of the ethnic Russian core of the Federation.
} 
Perm', and Orenburg oblasts would have had to either join the new region or face strong political and economic pressure from a wealthy Republic in the East. If formed, the republic would have become a very strong union bordering the Muslim Republic of Bashkortostan in the West, oil provinces of KhMAO and YaNAO in the East, and independent Kazakhstan in the South. Thus, the inclusion of Perm' Oblast' into the Volga FD has set off the pull of Yekaterinburg. Therefore, the inclusion of Perm' Oblast' into the Volga FD and its merger with KPAO has served three goals. First, it has enhanced the horizontal symmetry among the FDs - Northwestern, Volga, and Ural. Second, it has enhanced the symmetry within the Volga Federal District itself. Third, it has decreased the chances of separatism and redrawing of borders in the larger geographic area.

Finally, the second indirect outcome of the enlargement is the enlargement itself. I argue that after fifteen years of demarcation, it is an important precedent of state building! If future regional enlargements follow the precedent of Permskii Krai, eventually, horizontal symmetry would significantly improve. The containment of separatism (including ethnic separatism) would spread beyond balancing the ethnic constituencies at the level of FDs. On the federal level, it would enhance Russia's chances at successful renegotiation of the status of Chechnya.

It is clear that the region will find itself under more federal control. The governorship will be a Moscow-appointed position. The Duma will be large, and the margin of vote for parties to be represented in Duma is likely to increase to 7.5 or more 
percent, giving way to large centrist parties at the expense of small regional, possibly ethnicity-based, parties. Ethnic diversity, emphasized during the drive to enlargement, will likely fade in managed democracy and bureaucracy. The political outcome of the merger has so far achieved dubious results. From the standpoint of politics, the merger of Perm' Oblast' and KPAO benefits the state as a whole, particularly the federal government. The merged regions do not gain any political advantages in the enlargement race.

\section{Irkutsk Matryoshka}

Assessment of regional mergers that have not yet taken place is somewhat speculative. In sections which deal with Irkutsk and Ust'-Ordynskii Autonomous Okrug (U-OBAO) and Tyumen' and Khanty-Mansiiskii (KhMAO) and Yamalo-Nenetskii (YaNAO) Autonomous Okrugs, I only overview the nature of problems accompanying the enlargement. The enlargement debate has been at the center of political agenda in these regions for several years. The political process that may lead to enlargement of these regions is the main focus of my research on relations between Tyumen' and Irkutsk with "their" autonomous okrugs. I also assess the possible changes that it would entail for the regions and the symmetry of the Federation.

On its surface, the matryoshka of Irkutsk Oblast' and U-OBAO presents a more solid case for enlargement than Perm' and KPAO. I assess the progress to merger in Irkutsk through the prism of Perm's experience, analyzed in the previous section. 
Established as a national okrug in 1937, a small rural and agricultural U-OBAO remained a subunit of Irkutsk Oblast' until 1992. Irkutsk with its strong Soviet-built industrial base has always dwarfed the okrug. General political and economical data appears to justify the enlargement: Irkutsk is by far the stronger and larger region in terms of its area, population, and economy, than U-OBAO landlocked within it.

The enlargement scenario had been originally planned to follow Permskii Krai's experience. However, the enlargement referendum scheduled for 2004 never took place. The major cause of the failure lies in the lack of coordination among the regional and federal elites. As I noted in the analysis of Permskii Krai, enlargement process should be synchronized in order for a referendum to take place. Commenting on the loss of dynamism in the enlargement initiative, the chairman of Irkutsk regional legislature Gennady Istomin notes that 'synchronization of action in both Oblast' and Okrug is as important as the political will to merge." ${ }^{12}$ Unlike in Perm' and KPAO, Irkutsk and UOBAO have been unable to agree upon the terms of merger.

Legislative representatives of $\mathrm{U}-\mathrm{OBAO}$ originally backed the enlargement scheme. Two initiative groups, as opposed to thirty-two in Perm' and KPAO, were created in U-OBAO to explain the rationale behind proposed enlargement and to popularize the idea among voters. Subsequently, U-OBAO's legislature backed out, contending the viability of the proposed status of U-OBAO as a municipality in the

\footnotetext{
112 “Ob'yedinenie Irkutskoi Oblasti i Ust'-Ordynskogo Avtonomnogo Okruga Mozhet Zatormozit'sa" (Unification of Irkutsk Oblast' and U-OBAO May Slow Down), Regnum News Agency, May 14, 2004. Online at Www. regnum. ru/news $260845 \mathrm{html}$
} 
"greater" Irkutsk Oblast'. Seven of the seventeen representatives ${ }^{113}$ left the parliament floor in protest of the change in the U-OBAO's status in the enlarged region. ${ }^{114}$ Thus, the legislature of U-OBAO, a region smaller and poorer than KPAO, expressed its unreadiness to cede its federal status, and exchange it for a status of municipality. Paradoxically, should U-OBAO merge with Irkutsk Oblast' and retain its autonomous status, it would replicate the pre-1991 Soviet practice of incorporation of autonomous okrugs into oblasts and krais. Clearly, the revival of the RSFSR administrative division is not in the interest of the federal government, and is not what is expected of the enlargement. Therefore, balance of the federal and regional interests is yet to be attained. Otherwise, enlargement would not benefit either the federal government or Irkutsk Oblast

I suggest, that U-OBAO's concerns were not limited to the preservation of greater autonomy. They also included the lack of federal (and regional) incentives, discussed in the chapter on economics.

According to the existing initiative, merger of U-OBAO and Irkutsk would set yet another example of acquisition as opposed to merger. Given the relative size of the regions, U-OBAO can't compete for anything but status of municipal autonomy in the enlarged region. As it has already happened to KPAO, the independent status of UOBAO is to be reduced as a result of incorporation into a region with a clear ethnic

\footnotetext{
${ }^{113}$ Officially, legislature of U-OBAO consists of fifteen representatives. The number seventeen must include the speaker and the chairman.

144 "V U-OBAO Nachata Rabota nad Novoi Redaktsiei Pis'ma Presidentu RF" (U-OBAO Has Started Work at a New Draft of the Letter to the President of the RF), Regnum News Agency, May 26, 2004. Online at www.regnum.ru/news $267532 \mathrm{html}$
} 
Russian majority. Russian Duma deputy Vladimir Ryzhkov suggest enlargement is justified and is not to entail any problems, because there is no risk of separatism. He contends such risk exists if, for example, Altai Republic and Altaiskii Krai merge. It may backfire at the Russian Federation because of "strong separatist moods" there. ${ }^{115}$

The sequence of the enlargement process, which was successfully tested in Perm' and KPAO, has failed in Irkutsk and U-OBAO. Apparently, the failure has indefinitely stalled the enlargement process: referendum will not take place at least until 2006.

The possible future enlargement of Irkutsk Oblast' and U-OBAO would clearly solve yet another matryoshka case in favor of the federal government. The federal goals do not only include greater horizontal symmetry and efficient governance. As in the case of Permskii Krai, it is also aimed at containing regional ethnic separatism. If U-OBAO were successfully incorporated into Irkutsk, Buriat aspirations to unite in a single ethnic region within or without the Russian Federation would be undermined. If another merger - between Chita Oblast' and Aginskii Buriatskii Autonomous Okrug - were also to be implemented, the ethnic Republic of Buriatia would be finally doomed to fail its ambitious plans of the 1990s. ${ }^{116}$ As in the case of Perm', the ethnic issues of U-OBAO would promptly submerge in the everyday governance routine should the enlargement initiative succeed.

\footnotetext{
115 “'Ob'yedinenie Irkutskoi Oblasti i U-OBAO Ratsional'no i Vygodno, Schitaet Deputat Gosdumy Vladimir Ryzhkov" (Unification of Irkutsk Oblast and U-OBAO is Rational and Beneficial, Believes State Duma Deputy Vladimir Ryzhkov), Regnum News Agency, March 17, 2003. Online at www.regnum.ru/news/233212.html

${ }^{116}$ Like many other ethnic republics, Buriatia declared its independence in early $1990 \mathrm{~s}$. Article 60 of the Constitution of Buriatia defined the region's existence as a manifestation of self-determination of Buriat nation. Separatist moods in the Republic were quite strong until recently.
} 
Siberian regions like Irkutsk are highly important to the federal government. Sheer distance from Moscow - over 5,000 kilometers - allows the region to conduct a more independent policy. The population is quite skeptical towards federal authority. In addition to low turnouts at the last Duma and presidential elections in 2003 and 2004, Irkutsk is more likely to oppose federal initiatives. Latest protests in the region were organized by the Union of Right Forces in October 2004 to oppose the presidential initiative to appoint governors. Mocking his policy, protesters suggested appointing Ksenia Sobchak - a rich celebrity figure - as their new governor. They claimed the choice to be quite rational, if not ideal, since she is from St. Petersburg, knows Putin, and is the daughter of his former boss. ${ }^{117}$

Despite the economic incentives, discussed in the next chapter, the state apparently is unable to exert enough influence on Irkutsk' and U-OBAO to mediate the enlargement process as it did in Permskii Krai.

\section{Tyumen Matryoshka}

Official history of Western Siberia as a part of Russia dates back to 1637, when the first settlement was founded in Samarovo (present Khanty-Mansiisk). The region existed as Tobol'sk Gubernia until 1918, when its capital was relocated to Tyumen'. In subsequent decades the region was reorganized several times. The autonomous (national)

\footnotetext{
${ }^{117}$ Putin worked as a deputy to the governor of the City of St. Petersburg Anatolii Sobchak in early 1990s. See, for example, "V Irkutske Razdavali Listovki s Predlozheniem Naznachit' Gubernatorom Kseniu Sobchak" (Leaflets Proposing to Appoint Ksenia Sobchak as Governor Were Distributed in Irkutsk), Regnum News Agency, October 28, 2004. Online at www.regnum.ru/news $/ 350006$.html
} 
okrugs were first created in 1930, when resolution on "Organization of National Unions in Regions of Residence of Small Northern Ethnos" was adopted. ${ }^{118}$ KhMAO and YaNAO changed their status to autonomous along with the other okrugs in 1977. Upon adoption of the Russian Constitution (Article 65), the Okrugs gained their independence from Tyumen' Oblast'

The enlargement debate and administrative reform, having touched all autonomous okrugs, hasn't avoided Tyumen's Northern neighbors. However, having successfully started, the process stalled. The primary obstacles to the continuation of the enlargement are the oil deposits: as much as two thirds of Russia's oil production is concentrated in these sparsely populated areas (See Table 6, p. 181). Tyumen' Oblast', on the opposite, is resource-poor, its major assets being agriculture and manufacturing. The City of Tyumen' has lost much of its clout as a political and administrative center of the matryoshka to the autonomous capitals of Khanty-Mansiisk and Salekhard. While the okrugs' coffers are filling with oil rents, the oblast's development is slowing down. However, Tyumen' retains its high rank among Russian regions (See, for example, Chart 1, p. 92). Thus, the enlargement debate is not focused on attaching KhMAO and YaNAO back to Tyumen' Oblast', but, possibly, attaching the oblast' to the okrugs. ${ }^{119}$

All three subjects of the matryoshka are relatively equal from the standpoint of federal symmetry. Possibly, each one of them "deserves" to be an independent region.

\footnotetext{
${ }^{118}$ Decree of VTSIK (All-Union Central Executive Committee) "Ob Organizatsii Natsional'nykh Ob'yedinenii v Rayonah Rasselenia Malyh Narodnostei Severa," December 10, 1930.

119 Yekaterina Kon'kova, "Matryoshku Hotyat Skleit"' (Matryoshka to be Glued Together), Rossiiskaya Gazeta, June 4, 2004. Online at www.rg.ru/2004/06/04/ukrupnenie.html
} 
Pulling the blanket of political jurisdiction in direction of all three regions simultaneously cannot result in their successful merger. While the apparent leading region in the past has always been Tyumen', it is now unclear whether it, as a comparatively poorer region, can claim the laurels of the parent region.

If merger eventually proceeds as it had been planned in 2002-2003, its benefits would be reaped by Tyumen' and by the federal government through Tyumen'. The strength of the oil provinces would be diluted under the control from the capital of the enlarged region. The enlarged region may become one of the largest, and at least as of 2005 - the richest in Russia. Therefore, I conclude that the enlargement was originally negotiated without regard to enhanced governance or federal symmetry. Rather, the nature of reasons for enlargement is economic. I discuss these reasons in the next chapter.

The government appeared quite confident in success of its enlargement policies throughout Russia when it first "unleashed" the enlargement debate as part of administrative reform. However, alternative plans of enlargement appeared not only in form of all-Russia redistricting schemes, but also in opposition to state-sponsored initiatives. I suggest the process of enlargement stalled in Tyumen' because some particularly dangerous for central authority plans have publicly emerged. The threat to federal authority lies in the increase of nationalist attitudes among the otherwise politically inactive ethnic Nenets. Had their nationalism gained strength, they could have demanded the creation of a unified ethnic Nenets region in Russia. Considering that large ethnically defined regions traditionally have status of republics within Russia, and that 
the relations between the federal government and most of the twenty ethnic republics are complex and tense, the federal government would be likely to oppose any plans of formation of a new republic. The negative reaction from the federal government would also be based upon the fact that the territories of the Nenets settlements are rich with natural resources.

A perfect example of emergence of such scheme was the initiative of the Association Yamal Potomkam (Yamal to Descendants). It suggested merging all the Nenets autonomous okrugs - YaNAO, Nenetskii, and Dolgano-Nenetskii (Taimyrskii). ${ }^{120}$ Understanding the potential loss of enlargement referendum and tensions with ethnic Nenets, the government had to respond to the challenge elsewhere. A campaign for merger of Archangel'sk Oblast' and Nenetskii AO has yet been fruitless. However, it succeeded in supporting and sponsoring the enlargement of Krasnoyarskii Krai in order to exclude Taimyrskii AO from the Nenets plans. Thus, the formation of a unified Nenets region has been contained.

The merger of Tyumen', KhMAO, and YaNAO was abandoned in the summer of 2004, when the three regions signed and ratified a power-sharing agreement among themselves. $^{121}$ The agreement ensures independence of the okrugs from Tyumen' for at least another five years.

\footnotetext{
120 "Yamal Gotov k Ob'yedineniu s Tyumenskoi Oblast'iu" (Yamal is Ready to Unite with Tyumen 'Oblast '), Regnum News Agency, February 25, 2004. Online at www.regnum.ru/news/222426.html

121 "Dogovor o Razgranichenii Polnomochii mezhdu Organami Gosudarstvennoi Vlasti Khanty-Mansiiskogo Avtonomnogo Okruga, Yamalo-Nenetskogo Avtonomnogo Okruga, i Tyumenskoi Oblasti" (Treaty on Power-Sharing among Bodies of State Power of KhMAO, YaNAO, and Tyumen' Oblast'), Rossiiskaya Gazeta, July 22, 2004.
} 
By merging matryoshkas the federal government preempts the possible future mergers of ethnically defined constituencies and formation of new subjects of the federation with status of (ethnic) republics. Now, for example, KPAO would have to reinstate its independent status to merge with Komi Republic, which is now highly unlikely. The federal government will take every step possible to integrate and reintegrate autonomous okrugs with their former parent regions. Similarly, Buriats would be unable to unite should U-OBAO become an integral municipal autonomy of Irkutsk Oblast'. Ultimately, the federal government exercises the control over mergers because the proposed enlargement schemes should gain support of the government and the progovernment majority in the Duma prior to regional referendums.

\section{POLITICAL FACTOR IN THE ENLARGEMENT OF REGIONS}

The analysis of the political side of the enlargement in three regions of Russia has revealed no clear political benefits for the enlarged regions. In fact, the only winning party is the federal government. By diluting ethnic autonomy and preventing the crossfederal district integration, the division of the state, by all means, becomes more symmetrical in the first two case of Perm' and Irkutsk. The case of Tyumen', where a major factor in the proposed enlargement is probably its resource wealth, is different.

In a process of acquisition, rather than merger, former autonomous okrugs are being reduced to municipal autonomies. On the one hand, they are becoming units of municipal (local) administrative-territorial division. On the other hand, they retain a 
degree of cultural and linguistic autonomy. ${ }^{122}$ Should all okrugs merge with their former parent regions, a number of ethnically defined regions, as well as the overall number of regions, would decrease from 31 to 21 (See Table 1, p. 175). At the same time, horizontal symmetry may be enhanced. The okrugs' loss of constitutional status may increase the federal bargaining power vis-à-vis Chechnya and other ethnically defined Republics of the Russian Federation in the near future.

The enlargement of regions involving autonomous okrugs is a state-orchestrated process aimed at de-emphasizing the multiethnic character of the Russian Federation inherited from the RSFSR. Enlargement makes the federative structure of Russia less reflective of its multiethnic character as ethno-territorial divisions are substituted with administrative-territorial divisions. This transition shifts the political focus further away from ethnic (nationality) issues in the politics of federal-regional relations. In the process of rebuilding of the Federation, the federal government adopts the tactic of "masking" the unresolved ethnic questions and the future challenges of the nationalities policy, and the enlargement of regions is one such measure. ${ }^{123}$

It is clear that, should the present line of gosudarstvennost' policy continues, no substantive power-sharing agreements would be negotiated between the Russian Federation and its constituencies. The only exception is Chechnya, where reaching

\footnotetext{
122 This kind of autonomy is not political in nature. Rather, it is national cultural autonomy, the principles of which were formulated in the "Kontseptsiya Gosudarstvennoi Natsional 'noi Politiki RF" (Conception of the State National Policy of the RF), adopted by Presidential Decree No 909 on June 15, 1996. According to Article 26-2 of the Constitution, it is a right of all citizens and groups of citizens to preserve their native language, their beliefs, maintain their cultures and traditions. Moreover, article 69 of the Russian Constitution specifically guarantees the rights of the small indigenous peoples in the RF.

${ }^{123}$ In a similar manner, the federal government now disguises the reinstated Nationalities Ministry $(\operatorname{MinNats})$ as the Ministry of Regional Development (Ministerstvo Regional'nogo Razvitiya). See, for example, Fiona Hill, "Governing Russia: Putin's Federal Dilemmas," New Europe Review, January 2005.
} 
agreement is urgent. I suggest that the ultimate goal of the federal government is to address the constitutional status of Chechnya, but only once the rest of the Federation is rebalanced and the threat of Russia's disintegration is minimized. Politically, the enlargement of regions, and the decrease of the number of the ethnically defined constituencies represented at the federal level is a distinct step in this direction. 


\section{CHAPTER IV. ECONOMICS OF REGIONAL ENLARGEMENT}

The main argument of proponents of the enlargement of the Russian regions lies in the economic sphere. As I mentioned in the section on the enlargement debate, federal government, centrists in the Duma, and a number of political factions and actors across the political spectrum contend that mergers of some regions would improve the overall economic situation in the larger regions. Once enlarged, regions would complement each other's economy and develop more dynamically. Moreover, since most of the executed and proposed plans involve mergers of poor regions with rich regions, it would also eliminate a number of poor regions, which are not self-sufficient in terms of their income, from the structure of administrative division. Rich regions are said to balance socioeconomic standing of poor regions.

Therefore, according to Russia's leadership, the ultimate product of mergers would be a more horizontally symmetrical federation. In this section I first overview the regional asymmetry of Russia and the constitutional provisions for state's economy. Then I focus on the evolution and current trends of fiscal federalism emphasizing oil as a factor in the current state-federal relations. Finally, I assess the impact of regional enlargement on the economic well being of regions, and draw tentative conclusions. 


\section{ECONOMIC ASYMMETRY OF RUSSIAN REGIONS}

It is important to assess the economy of the Russian regions to understand the rationale behind the enlargement. For this purpose, I use four major sources. It is the data and analysis of the Ministry of Economic Development and Trade of the Russian Federation (Ministerstvo Ekonomicheskogo Razvitiya i Torgovli (MERT), State Statistical Committee of the Russian Federation (Gosydarstvennyi Komitet Statistiki Rossiiskoi Federatsii (GosKomStat), Ministry of Finance of the Russian Federation (Ministerstvo Finansov Rossiiskoi Federatsii (MinFin), and the Expert Rating Agency (Ekspert RA).

I use several parameters to assess the economic situation in the regions. The major indicators are gross regional product (GRP) and GRP per capita. However, GosKomStat - arguably not the most reliable source, compiles GDP data. Beliaev, for example, doubts the reliability of this indicator for two reasons. ${ }^{124}$ First, prices in Russia can be distorted as a result of the Soviet planned economy approach, which often includes unjustified subsidizing of whole sectors of the economy. Second, a large chunk of the economic activity is in the "shadow." ${ }^{125}$ Beliaev suggests considering the (intensity of) foreign direct investment (FDI) instead as a variable to evaluate the regional economic climate. Since my quantitative material is illustrative by nature, I rely on the GRP data of MERT in my tables, use the Expert RA surveys to complement it, and use a number of other sources, which include budgets of the Federation and its regions.

\footnotetext{
${ }^{124}$ Mikhail Beliaev, Putin's Russia: Is It a Doable Project? Demokratizatsiya, Vol. 12, Issue 1, Winter 2004, p. 13-39. Clifford Gaddy, Senior Fellow at the Brookings Institution, suggests to use "growth of industrial output" as a measure of regional economy.

${ }^{125}$ For a detailed study on this issue, see Clifford G. Gaddy and Barry W. Ickes, Russia's Virtual Economy, Washington DC, Brookings Institution Press, 2002.
} 
I start with assessing the overall socioeconomic climate of Russia based on Ekspert $R A$ eighth annual rating of the investment climate in Russia's regions Russia "Investment Rating for Russia 's Regions, 2002-2003," current asymmetry across Russia's vast territory. Researchers of the Agency suggest, "Russia will never accomplish the national task of doubling the GDP unless similar ambitious goals are also set at the regional level." Today, fewer than a quarter of Russia's regions are ready for this task. Expert RA's specialists determine regions' attractiveness to investment by examining them along the lines of investment risk and investment potential. ${ }^{127}$

While the research concludes that "the investment climate in Russia is stabilizing, and the number of marginalized regions is declining while the number of "middle-class" regions is growing," they also note that "only smaller regions, the autonomous subjects of the federation (okrugs), are exceptions to these general positive trends." In addition, the research concludes that performance of regional officials "makes the difference, especially when it comes to investment climate." (See Chart 1, p. 92).

\footnotetext{
${ }^{126}$ Available online at the "Gateway to Russia" website http:/www.gateway2russia.com/st/art 218314.php

${ }^{127}$ See Maps of Changes in Potential and Risk Indices 1997/98, 2002/2003 and Map of Investment Rating of the Regions of Russia, 2002-2003, Online at http:/www.gateway2russia.com/st/art 218314.php
} 
CHART 1: The leading regions as to the volume of investments per 1 official

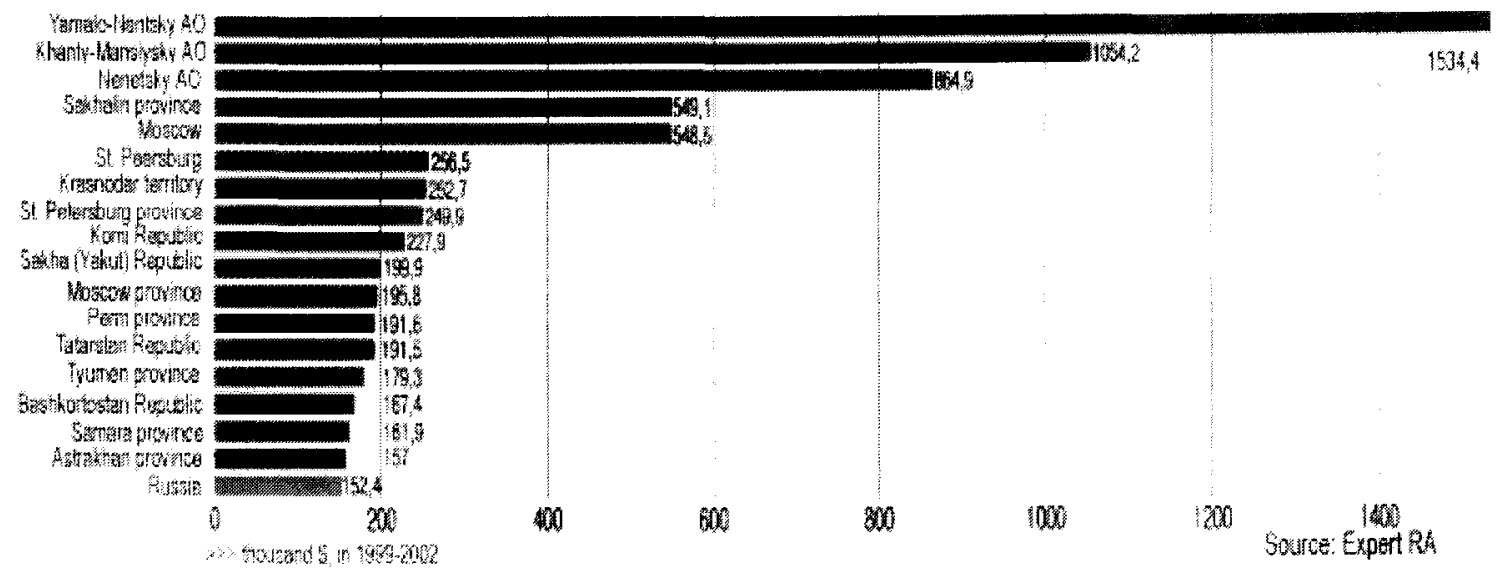

I partially disagree with Ekspert's findings. It is quite clear that all seventeen regions in the chart have two advantages over the majority of other regions. They either possess a strong manufacturing base (a legacy of the USSR) or substantial deposits of marketable natural resources (primarily oil, gas, diamonds, gold and other scarce metals and minerals). It may be reasonable to suggest that bad performance of other endowed regions can be attributed to their leadership, but the leading positions of the listed seventeen regions in the Federation are a consequence of their respective endowments. ${ }^{128}$

The Expert study describes an interesting find of the "wave effect," which may be used as an argument for regional enlargement. It suggests, "investment climate is not only defined by local authorities, but also by neighboring regions." In terms of patterns, it suggests "the Russian investment climate gets increasingly worse as one moves east and south; the waves of economic development expand in concentric rings from Russia's investment core." ${ }^{129}$ The pull weakens the further the region is from the investment core. Therefore, if the observation is accurate, then the poorer regions adjacent to richer

\footnotetext{
${ }^{128}$ A small number of regions, for example, Yaroslavskaya Oblast', have succeeded in diversifying economy and attracting investment. However, such cases are exceptional.

${ }_{129}$ The investment core includes North-Western and Central Russia.
} 
regions, like KPAO to Perm', are destined to prosper from their economic pull. However, while KPAO is among the ten poorest regions, Perm' Oblast' is among the top ten regions in Russia in terms of the performance of its economy. Pull doesn't always take the desired economic effect.

Thus, merger is not a necessary tool of enhancement in socioeconomic standing of regions. Moreover, sometimes pull of investment core doesn't exist because the core is distant. To facilitate the pull, regions should be merged across borders of other subjects of the Federation. Since it is impossible to merge, for example, Koryakskii AO and the City of Moscow, the wave effect argument presents a weak rationale for enlargement. Koryakskii AO's only choice for enlargement is merger with Kamchatskaya Oblast, ${ }^{130}$ Since Kamchatka is a very poor region itself, it is hard to picture that the wave effect would take place there. It is unlikely to foster short and medium-term economic growth in merger of poor regions.

\section{CONSTITUTIONAL PROVISIONS FOR ECONOMY}

The advocates of the enlargement of regions suggest that it facilitates the creation of a single economic space: it unites the economies, which had previously been confined within their regional borders. In fact, regional enlargement does make a somewhat plausible argument in terms of the economy of scale, because larger territory nominally constitutes larger economy. However, this argument for enlargement is quite weak if approached from the constitutional standpoint.

\footnotetext{
${ }^{130}$ Referendum on merger is scheduled for October 2005.
} 
Article 8-1 of the Russian Constitution provides for the single economy. It guarantees the "provision for the integrity of economic space, a free flow of goods, services and financial resources, support for competition, and the freedom of economic activity in the Russian Federation." It is supported by article 74-1, which prohibits internal customs, customs duties, and other obstacles to free movement of goods, services, and assets. Indeed, internal borders (among the Russian regions) are nominal. No customs offices or other obstacles to free movement of goods and services exist. Moreover, despite the existing constraints referenced in the chapter on demographics, the Constitution guarantees free movement of people in article 27. Therefore, a simple merger of some of the regions does not lead to significant enhancement of economic mobility.

It is a common misconception that Russia has undergone massive privatization, and that it is ruled by oligarchies. Even before the imprisonment of Mikhail Khodorkovsky on charges of tax evasion and fraud and partial renationalization of his oil company YUKOS, Russia was not privatized to the degree that it seemed. While the majority of the production assets indeed changed state for private ownership, the resource base of production and manufacturing, as well as much of the transport infrastructure is still lstate-owned, including property in federal and regional domains. Article $72-1-\mathrm{C}$ of the Constitution establishes "joint jurisdiction of the Russian Federation and the subjects of the Russian Federation (over) issues of possession, use and disposal of land, subsoil, water and other natural resources." Therefore, property under regional jurisdiction is also 
under federal jurisdiction, and vice versa. In addition, the federal and regional governments retain stakes in most of the natural monopolies - oil, gas, diamonds, and energy. These stakes are coupled with the administrative regulatory power of granting production licenses and permits, collecting taxes, and controlling monopolies.

In the USSR "autonomy was a way to retain resources at home to avoid redistributive consequences of all-union policies"." In principal, the conditions for regional leverage over the resources on their territory were even more favorable in the years following the collapse of the USSR when regions gained even more autonomy and the richer ones were able not only to retain resources, but also to benefit from them.

Article 9 of the Constitution declares "Land and other natural resources shall be utilized and protected in the Russian Federation as the basis of life and activity of the people living in corresponding territories." The key phrase here is "corresponding territories," which implies that regions have no obligation to share their natural geological endowment. However, it is the federal state that retains ownership of most of the subsoil resources, especially those dubbed "strategic."

Despite the clauses of articles 9 and 72, another constitutional norm granting the benefits of the natural resources to the people residing in the endowed region, the federal government has been revising the regime of the use of natural resources. The first step of bringing natural resources back under the jurisdiction and ownership of the Federation was the 1998 ruling of the Constitutional Court that "forests were the public property of

\footnotetext{
${ }^{131}$ Roeder, 1991, p. 219.
} 
the multinational people of the RF."132 Thus, the Constitutional Court's decision interpreted the articles 9 and 72 in favor of the federal government. Although the Constitution may be interpreted in Constitutional Court rulings and by federal laws, it can only be changed through a referendum, which was never conducted.

The next step in reclaiming the constitutional rights of the subjects of the Federation will be the adoption of the new law on mineral resources (subsoil natural resources), probably by the end of $2005 .^{133}$ The draft version of the law rephrases article 9 of the Russian Constitution by substituting the term "corresponding territories" with "the territory of the RF." Regardless of phrasing, the ultimate purpose of the adoption of this law is to solidify the federal nature of ownership of natural resources primarily by stripping the regions of their constitutional rights to prioritize the use of natural resources for own benefit. ${ }^{134}$ Thus, the enlargement of regions is an unnecessary process if its purpose is the redistribution of the control over natural resources among enlarged regions. The natural resources would be put under the sole jurisdiction of the state, enabling it to regulate rents and direct their flow. The principle of joint jurisdiction will be applied from top-down. The federal center alone will determine and assign the functions that regions will assume in regulating natural resources.

\footnotetext{
${ }^{132}$ Ruling on the Issue of Constitutionality of the Forest Code (Lesnoi Kodeks) of the RF, Constitutional Court of the Russian Federation, January 9, 1998, in VKS RF, No 2, 1998, p. 5-18.

${ }^{133}$ Law on Mineral Resources (draft version), the Ministry of Natural Resources of the Russian Federation, March 5 , 2005, Newer versions may be available in Russian online at www.mnr.gov.ru

${ }^{134}$ President of Tatarstan Mintimer Shaimiev takes the same stand on this issue. See, for example, Mintimer Sahimiev, "Nedra Dolzhny Rabotat" (Subsoil Mineral Resources Should Work), Rossiiskaya Gazeta, March 1, 2005. Online at www.rg.ru/20050301/shaimicv.html
} 


\section{FACTOR OF EXTRACTIVE INDUSTRY IN FEDERAL FISCAL POLICY}

Less than a decade ago, Russia's federal government was bankrupt. President Yeltsin was forced to sell the state stakes in major industries to organize a solid elections campaign and stay in power. In 1996 this policy gave rise to the notorious Russian oligarchs. The situation in the country has changed. Since early 2000 s, the Russian federal budget maintains surplus. The state created a Stabilization Fund, which accumulates money at twice the pace it was expected. Russia is paying its foreign debt, which in 2005 decreased to about 30 percent of the GDP from over 50 percent a few years before. After the default of 1998, Russian GDP has rebounded and has been growing at a rate of as much as 7 percent per year. Most of these positive changes in the Russian economy originate in the state's enormous oil wealth.

Twenty-first century Russia is an energy superpower. It exports as much oil as Saudi Arabia, or about one third of OPEC's oil exports. In 2004, it produced 457.8 million tons of oil, and exported 257.4 million tons, or 56.1 percent of that amount. ${ }^{135}$ Russia's current relative well being, and its power, may be largely attributed to its resource wealth, primarily oil and gas, but also to diamonds, and other mineral resources. ${ }^{136}$ The distribution of mineral deposits (and locations of extractive industries) is confined to a relatively small number of regions and is skewed to the coldest and least populated areas of Siberia. However, even regions with relatively small deposits of oil

\footnotetext{
135 "O Sostoyanii Rynka Nefti v 2004 Godu" (On the Conditions of Oil Market in 2004), GosKomStat, January 2005. Online at www.gks.ru/scripts/free/lc.exe?XXXX03F.1.10.1/050150R

${ }^{136}$ See, for example, Fiona Hill, Energy Empire: Oil, Gas, and Russia's Revival, London, The Foreign Policy Center, September 2004. Available online at http://brookings.edu/views/articles/Fhill/20040930.pdf
} 
and gas and other valuable commodities are quite advantageously positioned with respect to the resource-poor regions. The few exceptions of resource-poor regions that are economically prosperous are the unnaturally oversized regions - the Cities of Moscow and St. Petersburg, both independent subjects of the federation, and, possibly, the City of Nizhny Novgorod, whose large economically lagging region, however, burdens it. The only reason why regions like Khanty-Mansiiskii, Yamalo-Nenetskii, Chukotskii and Dolgano-Nenetskii Autonomous Okrugs, Republics of Tatarstan and Yakutia, and, for that matter, Perm' Oblast' have secured their high positions in the socio-economic and investment rankings of the Russian regions is their "natural" richness. Therefore, the effective reforms initiated by "strong" and "uncorrupted" regional leaderships should be perceived as secondary factors to their success.

Table 6 (p. 181) demonstrates the competitive edge of the naturally endowed regions. As early as 2001 when oil prices were only beginning to grow, the resourcerelated revenues in YaNAO's budget exceeded 30 percent, KhMAO's were almost 20 percent, and Tatarstan's were about 15 percent. At the time, an average share of resourcerelated revenues in regional budgets stood at around 6.5 percent. Given that a significant portion of revenue comes from sources indirectly related to resource economy, the figures are quite high. Dependence of such regions on their resources is very high. The share of resource-related budgetary revenue for the City of Moscow, the best-performing Russian region, stands at only 0.2 percent. At the same time, Moscow, and some other regions are homes to a variety of Russia's major enterprises. The resource-rich regions only have significant presence of production companies. Their economies are 
undiversified and heavily dependent on oil and other resources. Naturally, they cherish their only sources of wealth.

Equity is an integral part of federations. It may be divided into two components: social solidarity (cohesion) on the federal level and conformity of expenditures to local preferences and ideas of equity within regions. ${ }^{137}$ Rich regions are reluctant to share their resources with the poor regions or the federal government. The federal government and the poor regions, on the opposite, are interested in creating conditions under which the endowment of some provinces - translated into taxes and economic growth - is put to the use and benefit of the federated state and all of its constituencies. Since it is impossible for the state to overcome the geographical and geological constraints of resource distribution, it seeks to employ all legal (and, possibly unlawful) means to reclaim the natural resource rents. ${ }^{138}$ Its aggressive redistributive policy is implicitly fueled by resentment of poorer regions vis-à-vis their resource-rich neighbors, over which they have no political leverage. They argue that the natural resources should not give a competitive advantage to the populations that "happen to reside" in the naturallyendowed regions, and that the rents from the mineral wealth should be collected by the federal government in full and then fairly redistributed among the subjects of the Federation. Thus, a greater balance among the poor and the rich regions would be achieved.

\footnotetext{
${ }^{137}$ Alastair McAuley, The Determinants of Russian Federal-Regional Fiscal Relations: Equity or Political Influence? Europe-Asia Studies, Vol. 49, No. 3, 1997, p. 431-444, at p. 432.

${ }_{138}$ For example, see Clifford G. Gaddy, Perspectives on the Potential of Russian Oil, Eurasian Geography and Economics, 45, No. 5, July 2004, p. 346-351.
} 
In recent years, the extent of regional leverage over the regional mineral wealth has indeed shifted. Of many taxes that have shaped the budgets of resource-rich provinces, a single most important tax is the tax on the extraction of mineral resource (Nalog na Dobychu Poleznylh Iskopaemykh - NDPI). The early-adopted versions of the Russian Tax Code permitted regions to retain NDPI in full. In early 2000s, following the latest spike in oil prices, the federal government realized that it had been losing significant revenues from oil production and export. To claim a greater share of these revenues, taxation law was amended to increase the rents and divert them to the federal budget, and, starting in 2005, all of the NDPI is transferred directly to the federal budget. There are two "losers" of the diversion process - the private producers and the regional and municipal budgets of oil and other resource-rich provinces. The most common argument made in support of federalization of NDPI is that it is a form of rent, and, since the subsoil mineral resources are the property of the state as a whole, it should be centralized. Since it is property of the state as a whole, no particular population (or ethnic group) would have a prerogative to utilize natural resources. Rather, rents belong to the population as a whole. ${ }^{139}$

However, the state doesn't have monopoly over the extraction and sale of natural resources. With an exception of the Russian state natural gas company Gazprom and the oil company Rosneft', they are produced by a number of private enterprises. Large resource monopolies, which became known as oligarchies in the late $1990 \mathrm{~s}$, tend to dominate regional production, refining (processing), and distribution markets. Head of

\footnotetext{
${ }^{139}$ See, for example, A. D. Andriakov, "Kak Podelit' Pirog?" (How to Share the Pie?), Interview at Radio Mayak, August 19, 2004. Online at www radiomayak.ru/schedules/682/16793.html
} 
Russian Antimonopoly Service (FAS) Igor' Artemiev admits, "Regions are divided into spheres of influence among a few resource companies." ${ }^{140}$ He contends that regional monopolies should not have access to new resources, and that other companies - those without close ties with regional political elites - should dilute monopolies. The draft law on Mineral Resources contains a clause, which would restrict regional monopolies from bidding on new deposits if they already hold over 80 percent of exploration and operation licenses in the region. Indeed, certain companies have clearly monopolized regional markets in the 1990s. LUKoil dominates in Komi Republic, Nenetskii AO, Perm' Oblast', and Volgograd Oblast'. Former YUKOS subsidiaries dominate in Tomsk Oblast'. Sibneft' dominates in YaNAO and has booked exclusive right to perspective fields in Chukotka. Even state-owned Rosneft' holds a dominant position in the Northern Caucasus and Krasnodar Krai. ${ }^{141}$

The enlargement of regions along with the measures proposed by $F A S$ may prove effective in curbing the regional monopolistic dominance, although it would be hard to alter it. In Perm' Oblast', LUKoil's already effectively controls oilfields, refineries, and distribution chains. Merger of Perm' and KPAO is likely to only increase the company's monopolistic standing. It already holds rights to the few oilfields in KPAO, and the merger will effectively merge not only LUKoil holdings in Permskii Krai, but also all three of the LUKoil's main Russian on-shore fields - Permskii Krai, Komi Republic, and Nenetskii AO (see Table 6, p. 181). However, oil reserves of Perm' are only about three

\footnotetext{
${ }^{140}$ Aleksandr Beliakov, "Minprirody Ne Otdast Nedra Regional'nym Monopolistam" (Minsitry of Natural Resources Will not Give Resources to Monopolies), Vedomosti, No 177 (1217), September 29, 2004.

${ }^{141}$ Similar pattern may be found in other extractive industries: in coal industry - Tulaugol' in Tula Oblast' and SUEK in Eastern Siberia; in diamond industry - Alrosa in Yakutia.
} 
percent of tapped Russian fields. They have been exploited since 1950s, and the production is not going to increase.

Irkutsk' Oblast' and U-OBAO presents a case similar to Perm' and KPAO. As noted, U-OBAO is a resource-poor agricultural region, while Irkutsk, on the opposite, is heavily industrialized and somewhat rich in resources: major aluminum production plant in the second largest City of Bratsk; Kovykhta gas field is among the East Siberian most promising deposits to be tapped by TNK-BP and Gazprom; one of Russia's great Northern Rivers, Angara, is dammed by hydroelectric power stations, generating most of the region's electricity. Merger would not alter the operation of regional monopolies. The budgetary extractive industry-related income would increase to 3.3 percent, which is an insignificant figure even in relation to Permskii Krai and Russia's other resource-rich regions, making this factor an insignificant goal for enlargement.

The situation is different in the Russia's "oil treasury" of Tyumen' Oblast", KhMAO, and YaNAO. Merger of this matryoshka would facilitate greater competition among Russia's large oil and gas companies represented in the region. It is likely to decrease the level of monopolization in the Western Siberian oil production. However, there is a major downside to this merger. The enlarged region would account for as much as 67.7 percent of Russian oil production, as opposed to only 2.2 percent in Permskii Krai. The regional budgetary revenues from oil would average at over 25 percent, while the figure would remain at 6.3 percent in Perm'. Thus, the merger of the Tyumen' matryoshka would create an extremely powerful region. Consequentially, the 
enlargement plans are likely to fail, as they did in the case of the creation of the Ural Republic. The federal government wouldn't want to create an industrial region in Russia powerful enough to dictate its terms to the Federation and to conduct independent domestic and foreign policy.

Unless the federal government finds mechanisms to effectively keep rich okrugs in line, their merger would not be likely. The mounting state pressure is noticeable in the YUKOS affair. Minister of Finance Aleksey Kudrin suggested to the government of KhMAO to share the 52.3 billion of expected YUKOS' tax return with the Federal government. ${ }^{142}$ Kudrin requested 35 billion rubles, or two thirds of the sum to be transferred to the Federation to form the fund for balance of the revenues of the regional budgets. ${ }^{143}$ Another 7 billion were requested for the federal budget as a two-year returnable loan. KhMAO has agreed but took a counter action. On March 16, 2005 KhMAO's governor Aleksandr Filipenko announced that the okrug would establish a stabilization fund, similar to the one which operates in the Federation. ${ }^{144}$ Fiscal federative relations involving oil revenues are quite complex, and may serve as obstacle to the federal policy of regional enlargement.

Describing provincial strategies in their relations with the federal center, Solnick suggests that "in the case of the federal bargaining, a bloc of territories able to act together can make a far greater credible threat of disrupting state affairs than any single

\footnotetext{
142 "Minfin i Sub'ekty Federatsii Delyat Milliardy YUKOSa" (Ministry of Finance and the Subjects of the Federation Divide YUKOS' Billions), Neftegazovaya Vertikal', August 9, 2004. Online at http:/ngv.ru/lenta sign, hsql?id-51252

${ }^{143}$ Balance of regional budgets of the subjects of the RF is determined as a share of regional revenues to regional expenditures. In 2004 at least 40 deficit regional budgets needed to be balanced with federal money.

144 "V Khanty-Mansiiskom AO Sozdaut Stabilizatsionnyi Fond" (KhMAO to Establish Stabilization Fund), News Agency Regions. Ru, March 16, 2005. Online at www.regions.ru/newsarticle/news/id/1 764444.html
} 
territory acting alone.". ${ }^{145}$ The creation of such regions would have threatened the balance between the federal and regional power. I am afraid that a similar unwanted result could actually be achieved had Tyumen' Oblast' merged with KhMAO and YaNAO. Larger regions may create more favorable conditions for monopolies to negotiate at the regional level as there would be fewer administrative barriers. However, monopolies would become more visible for polpreds, FAS officials, and the tax authorities on the "canvas" of a larger constituency. Appointment of governors may also be one of mechanisms to keep the merged region in line with the federal policy.

In terms of both horizontal and vertical symmetry, the enlargement of Tyumen' would have created a disproportionately large and economically strong subject of the federation. The toughness of Putin's vertical of executive power would be put to test if constituencies as large as Tyumen' matryoshka were formed.

While the Russian budget has maintained a surplus as a result of the high oil and gas prices, few subjects of the federation were able to extract similar benefits from this advantageous situation. The exhaustive list of the benefiting regions is limited to a dozen resource-endowed territories, major refining centers, the city of Moscow - also the financial capital of Russia, and the federal government. In addition, the booming oil industry generated growth in linked industries, which means that the heavily industrialized regions generally wealthier than the majority of Russia's regions regardless

\footnotetext{
${ }^{145}$ Steven L. Solnick, "The Political Economy of Russian Federalism," Problems of Post-Communism, NovemberDecember 1996, Vol 43, Issue 6, p, 13-26.
} 
of commodity prices are often also the beneficiaries of the oil-fuelled business climate. ${ }^{146}$ Therefore, Russia's oil-fuelled economic recovery is not a panacea for the regional economic troubles. In fact, it only enhances the economic asymmetry among the regions, and further marginalizes the poor, cold, agricultural, and politically unstable constituencies. The exhaustive list of these depressive regions includes all of Russia's autonomous okrugs, except naturally endowed KMAO, YaNAO, and Evenkia (since 2004). ${ }^{147}$

The positive economic effects of direct federal interference to redistribute resource rents and breakdown monopolistic markets may be limited in Perm' and Irkutsk, but may have impact Tyumen'. However, it is not in the state's best interest to create an oversize naturally-endowed region in Western Siberia, unless the federal government is confident that it would be able to influence and veto the region's decisions through mechanisms of appointment of governors, party list-based elections, as well as centralization of resource rents.

Centralization of resource rents and dilution of monopolies may spark strong opposition in regions. While it is improbable in the enlarged Perm', Irkutsk, and even in Tyumen', it is quite possible in other constituencies. Ethnic republics like Tatarstan, Bashkortostan, and Yakutia are heavily dependent on resource rents, and their political

\footnotetext{
140 For example, Clifford Gaddy has established a strong correlation between the increase in oil output and manufacturing of railroad cars. Impact of oil-spurred growth is evident in many Russian enterprises, which were net loss-makers as late as early 2000 s, and are now showing strong signs of recovery.

${ }^{147}$ Another exception is Chukotka, the only autonomous okrug to win its full independence, and, therefore, unaffiliated with either a krai or an oblast'. Despite the small population and relative abundance of resources, it runs a high budget deficit and was declared bankrupt in 2004.
} 
elites have strong connections with regional oligarchies. These regions may put up a fierce political fight for their right to use their natural resources.

Also, enlarged constituencies, like Tyumen' Oblast' and Krasnoyarskii Krai may offset the competitiveness of the naturally endowed ethnic republics on the level of the Federation. Moreover, dilution of monopolies in the enlarged Tyumen' may be understood as FAS' threat to republican monopolies - as signal to ethnic republics to open their monopolized markets to outside companies.

In addition to increased taxation, the federal government has invented two schemes to divert oil profits and destroy regional monopolies. First is revision of privatization results, which was effectively deployed to dismantle and renationalize the YUKOS Oil Company in the infamous back-tax case initiated in 2003. The second has a more limited and indirect effect. Instead of outright nationalization, it facilitates distribution of rents over a greater territory through merger of resource-rich with the resource-poor regions.

\section{DIVERSIFICATION OF REGIONAL ECONOMY AND ENHANCEMENT OF CONNECTIVITY OF RUSSIA}

Enlargement schemes are not limited to balancing the difference of resource abundance among merging regions, but also pursue two important regional goals. First, enlargement of regions is aimed at diversification of economies in greater regions. Second, it enhances the connectivity of the Russian state as a whole by connecting the 
existing and potential areas of spatial development within the enlarged regions. In the subsequent paragraphs I discuss the underlying reasons for the need to diversify regional economies and enhance connectivity of the state and the possible effects that the regional enlargement may have on diversification and connectivity.

\section{Diversification as Panacea against Resource Curse at Regional Level}

Russian economic development has two major constraints - the size and geography of the country, including the location of mineral deposits, and the heritage of Soviet economic planning (or Gosplan) ${ }^{148}$ for the location of manufacturing sites. The most precious and strategic deposits of Russia are dispersed throughout the large and cold area of Siberia. Soviet manufacturing was also scattered across the country. In the areas developed immediately before and during the World War II, and in the postbellum decades production sites were often complemented with manufacturing. However, many of the areas created by Gosplan's decrees in the Soviet Union's later years never developed a diversified economy. They grew and overgrew, remaining resource appendices of manufacturing sites located in other areas.

The RSFSR's autonomous okrugs were parts of greater regions, which - at that scale - combined both production and manufacturing, or agriculture and manufacturing, providing for some diversification of economy in larger regions. Thus, in case of a bad

\footnotetext{
${ }^{148}$ Gosplan is an acronym of "Gosudarstvennoe Planirovanie" or "State Planning." It was a state planning agency responsible directly to the Soviet supreme authority, Communist Party of the Soviet Union Central Committee, for drafting and implementing five-year economic plans.
} 
harvest or exhaustion of a resource, or relocation of industry, the regional economy was still able to perform reasonably well without outside help. With time the regional boundaries lost their meaning as a result of redistributive policies and distorted prices of the planned economy. After all, economies at regional level didn't require diversification, because of the nature of ownership and high centralization.

Upon the disintegration of the USSR, the system of planned economy fell, and ties among the all-Union and RSFSR constituencies broke. Although the RSFSR (Russia) didn't disintegrate, its structure grew ever more complex. Some ethnic republics attempted to gain independence (Chechnya, Tatarstan, Buriatia); autonomous okrugs seceded from their host oblasts and krais and established themselves as independent federal constituencies. The largely production-oriented economies of the AOs lost the connectivity with the manufacturing sector traditionally located in administrativeterritorial components (oblast', krai). Thus, economies of the former matryoshka regions lost the little integrity that they had within the greater Soviet economy. At present, their economies remain undiversified.

The federal government justifies the proposal to merge some regions, including those studied in this paper, by economic reasons. Speaking days before the referendum on the merger of Perm' Oblast' and KPAO, President Putin remarked, "life has shown that the division into two separate regions was not economically justified." ${ }^{249}$ In a later interview, Putin once again stressed, "Many regions are not economically viable on their

\footnotetext{
${ }^{149}$ In the Spotlight, October 31, 2003, www.kremlin.ru/eng/text themes/2003/10/312052_54807.shtm/
} 
own." 150 Indeed, ideally, regions should be viable as economically viable regions are least dependent on the federal government. Moreover, it is desirable that regions are "fairly equal in population and wealth or at least balanced geographically or numerically in their inequalities if non-concentration is to be maintained."151

The Russian economy is both concentrated and dispersed. In terms of concentration, production is confined to geographical location of resources, and manufacturing (non-resource industry) is confined to industrial areas developed by Gosplan for reasons including security threats - WWII and the Cold War. At the same time, the industrial areas - at least in the northern and eastern parts of Russia are located at considerable distances from each other. Often they are completely detached from the "mainland" throughout the year or during winter months. It is virtually impossible and probably outright useless to integrate such industrial pockets. Combination of resources, manufacturing, and transportation is simply an unachievable task for the economy at such location. Despite the logic of this realistic assessment, the enlargement of regions is said to bring diversification to even most underdeveloped and remote areas by moving regional administrative boundaries.

I argue that redrawing of boundaries would not diversify regional economies. Diversification of many of the Russia's northern areas - including the autonomous okrugs studied in this paper - would not be enhanced unless the federal government redeploys mechanisms of Gosplan. Such redeployment would impede economic growth

\footnotetext{
${ }^{150}$ Excerpts from the President's Live Television and Radio Dialogue with the Populaiton, December 18, 2003, Official Website of the President of Russia. Online at www.kremlin.ru/eng/text/speeches/2003/12/18/1200 57480.shtml

${ }^{151}$ Elazar, 1987, p. 170.
} 
and reverse the country's progress towards market economy. Yuri Perelygin of NorthWest Center for Strategic Development contends, "Manufacturing in the Far North is associated with high costs." 152 This position is thoroughly explained by the Brookings scholars Fiona Hill and Clifford Gaddy. In "The Siberian Curse" they suggest the population should "evacuate" the north for Russia's warmer and more developed European part to decrease Russia's "traditional" inefficiency of maintaining large cities and factories in the North. There is no antidote to the climatic conditions of the North: even should the global warming make the climate milder, it would create a whole new set of climatic problems like floods and droughts. For now, attempts to sustain and develop the existing infrastructure would remain a perpetual obstacle to Russia's development.

Russia is not ready to part with Siberia - by relocating population and switching to rotation shift method of exploiting its riches. In search for a solution Perelygin suggests, "Only widespread application of modern technologies can make it (economy of the Russia's North) competitive." If the government intends to apply modern technologies in the North, they are certainly most needed in the natural resource sector. Economic diversification would not create competitive industries outside of the resource sector - largely due to the high costs of production in the North. It can only be created artificially - by merging regions.

Economic diversification is pronounced as one of the goals of regional enlargement, and is relevant to discussing the enlargement of regions in all the three

\footnotetext{
152 Interview with Yuri Perelygin, Scientific Head of Center for Strategic Development "North-West." In Mariya Kravtsova, "Severnyi Vyvoz" (Northern Shipping-Out), Expert, No 26, July 12-18, 2004, p. 68-73, p.71.
} 
studied cases. As noted in the previous chapters, there is a stark contrast between the economies of the oblasts and "their" autonomous okrugs. The economies of the former are heavily industrialized (machine building, VPK, energy generation, etc.). The economies of the latter are resource and agriculture-oriented. The degree of regional economic differences is supported by the data on emissions (see Table 7, p.111).

Table 7. Emissions of Polluting Substances into the Atmosphere in Selected Russian Regions, 2003

\begin{tabular}{|c|c|}
\hline & $\begin{array}{c}\text { Emissions of Polluting Substances } \\
\text { into the Atmosphere (thousands of } \\
\text { tons) }\end{array}$ \\
\hline Russia Total & 19,829 \\
\hline Central Federal District & 1,509 \\
\hline City of Moscow & 97 \\
\hline Volga Federal District & 3,143 \\
\hline Republic of Tatarstan & 270 \\
\hline Perm' Oblast' & $723(721)$ \\
\hline including Komi-Permyatskii AO & 2 \\
\hline Ural Federal District & 5,664 \\
\hline Tyumen' Oblast' & $3,421(72)$ \\
\hline including Khanty-Mansiiskii AO & 2,435 \\
\hline and Yamalo-Nenetskii $\mathrm{AO}$ & 914 \\
\hline Siberian Federal District & 5,609 \\
\hline Irkutsk Oblast' & $520(518)$ \\
\hline including Ust'-Ordynskii Byruatskii AO & 2 \\
\hline
\end{tabular}

Source: Osnovnve Pokazateli Okhrany Okruzhaushei Sredy po Regionam Rossiiskoi Federatsii (Basic Indicators of Environmental Protection by Regions of the Russian Federation), GosKomStat, 2003. Online at http:/www.gks.ru/BGD/frec/B oxran/IswPrx.dll/Stg/0050.htm

The amount of emissions differs from region to region. Moscow's low figure is largely a result of movement of production to the Moscow Oblast', a separate region. However, the whole Central Federal District only emitted 1, 509 thousands of tons - a 
small amount compared to 5, 664 thousand tons in the Ural and 5, 609 thousand tons in the Siberian Federal Districts. These figures demonstrate that most of the heavy industry is located East of Moscow, and more than half of it to the East of the Ural Mountains. The Republic of Tatarstan is another odd case. Despite its sizeable petro-chemical complex, emissions only amount to 270 thousand tons. This may be the result of the costly application of cleaner technologies. Like Moscow, the Republic is a rich region, and can allocate substantial financial resources to decrease emissions.

Pollution data within the FDs and in individual regions demonstrate the degree of industrialization. The contrast between the oblasts and the okrugs is remarkable. In the newly formed Permskii Krai, KPAO emitted only 2 thousand tons in 2003 while Perm' emitted 721 thousand tons. Similarly, U-OBAO emissions were 2 thousand tons versus 518 thousand tons in Irkutsk. Emission figures are significant in two of the three Tyumen' matryoshka regions. In YaNAO and KhMAO environmentally outdated technologies of oil and gas production and extensive flaring of the extraction byproducts of crude oil cause most of the region's pollution, which accounts for over half of the emissions in the Ural FD. Tyumen' Oblast's emissions stand at unimpressive 72 thousand tons.

The small amounts of emissions in KPAO, U-OBAO, and in Tyumen' Oblast' testify to the non-industrial nature of their economies. KPAO's economy is dominated by logging and supplying timber to the processing plants in Perm'. U-OBAO is a small agricultural region - to the extent the climatic conditions allow agriculture in the area. 
Tyumen' Oblast' has a diversified economy: machine building and metal-working industry accounts for about 45 percent of its industrial output, followed by timber and woodworking industry with 10 percent. Other sectors include agriculture and small and medium-size enterprises. ${ }^{153}$ The divide of regions by the production and processing and manufacturing specialization of their economies is apparent. Agriculture and logging may be harmful to the environment, but they produce little emission. On the opposite, extensive oil production, refining, petrochemical, and heavy machinery industries are notorious for the amount of pollution.

The contrast in regional economic specialization, and the state of regional economy in general can be inferred from the data on major enterprises based in regions. Oil production is another factor complementing the data on enterprises (See Table 6, p. 181). The list of Top 100 Russian Enterprises compiled by AK\&M Rating Center in 2003 features three companies headquartered in Perm', two in Irkutsk, and one in Tyumen'. Moscow, for example, is headquarters to six of the top 100 enterprises, Republic of Tatarstan - to five. KPAO, U-OBAO, KhMAO, and YaNAO, as well as war-torn Republic of Chechnya headquarter none. Regional creditworthiness ratings of the eightynine Russian regions are distributed correspondingly. Moscow tops the list, Tatarstan is at place thirteen, and Perm' and Irkutsk at places nine and forty correspondingly. KPAO, UOBAO, and, for that matter Chechnya, are at the very bottom of the list - seventy-nine, eighty-two, and below eighty-seven $(87,88$, or 89$)$ correspondingly. Despite absence of headquarters of major Russian enterprises, creditworthiness rating is outstanding in the

\footnotetext{
153 "Naibol'shii Vklad v Ekonomiku Tumeni Vnosyat Predpryatia Mashinostroeniya i Metalloobrabotki" (Machine building and Metal-working Industries are the Greatest Contributors to Tyumen 's Economy), Region-Tyumen' Broadcasting Company, February 28, 2005. Online at www.tyumen.rfn.ru/rnews.html? id=19225\&cid 6
} 
Tyumen' matryoshka. Tyumen' Oblast' is ranked four, KhMAO - three, and YaNAO five. Their top investment ranking is the result of the on-going Russian oil boom. The amount of oil production and the presence of production companies in these regions are the key to understanding their competitive edge and high ranking.

In 2004 the depleting oilfields of Perm' and Tatarstan yielded only 2.2 and 6.5 percent respectively. Chechnya produced only 0.4 percent contrary to the myth that the war in Chechnya is the war for oil. Irkutsk produced 0.02 percent while KPAO, UOBAO, and Moscow produced none. Tyumen' Oblast', also suffering from the depletion of the few existing fields produced only 0.3 percent, while its northern counterparts produced over 67 percent of Russia's oil - 55.8 and 11.6 percent in KhMAO and YaNAO respectively.

Tyumen' matryoshka has significant operations of all Russian oil giants, except LUKoil. Rusia-Petroleum, TNK-BP, and Gazprom dominate the developing Irkutsk oil production. Tatneft', Tatarstan's regional oil monopoly produces most of the Republic's oil. All Chechen oil is produced by Grozneft', a subsidiary of the state-owned Rosneft', and by illegally operating small enterprises (not accounted for in statistics). Significant presence of a number of competing oil giants in the Tyumen' matryoshka accounts for its high creditworthiness and the overall good performance of their economies, as was previously noted. Production in other regions featured in Table 6 (p. 181) - Perm', Irkutsk, Tatarstan, and Chechnya is largely monopolized. 
Hypothetically, regional enlargement has several implications for the regional economies. First, they would be more diversified: the resource sector would be balanced by the non-resource sector. Second, regional monopolies in the resource sector would be diluted. Third, regions would be less prone to income shocks if world oil prices fall.

\section{Income Shocks and De-Monopolization of Regional Economies}

The International Monetary Fund (IMF) has established a high correlation of "regional revenues and expenditures with oil shocks." ${ }^{54}$ The current stability of regional incomes and economic growth has only lasted for the last five years. In January 1999, when global oil price fell below nine US dollars per barrel, Russian economic outlooks were grim. If it hadn't been for the devaluation of the ruble against dollar, oil producers would have slipped into a major crisis, dragging whole regions, and possibly the country in a deeper crisis. In fact, oil shocks affect the Russian economy as a whole. Low oil prices change the pattern of federal transfers to all Russian regions. I suggest the cyclical nature of oil taxes, and the correlation between oil prices and economic growth have alerted the federal government and triggered concerns. One of the set goals of regional enlargement is diversification of the economy of the resource-rich regions and economic development of the generally poor. Theoretically, it should enhance the viability of regions when commodity prices are low, since diversified economies can absorb shocks easier. Also, markets of undiversified regional economies are prone to monopolization

\footnotetext{
154 "Russian Fcderation: Selected Issues," IMF Country Report No 04/316, Washington, DC, September 2004, at p. 87.
} 
and monopolistic deals, and regional enlargement is seen as one of the ways to dilute monopolies and foster competition. ${ }^{155}$

\section{Diversification of Regional Economies}

In addition to shock absorption, an alleged advantage of regional enlargement is diversification. Gosplan largely shaped economies of the state and its regions in the postWWII period. Despite richness in natural resources, regions wouldn't have grown and developed the way they have since the structure of their economies was planned, and each of them served a specific purpose in the state-controlled economy. Diversification was never the goal of the state, so it had neither been planned nor encouraged.

MERT, having briefly assumed functions of nationalities and regional affairs in 2004 , drafted a total of twenty programs of regional development. Of the twenty, only one was designed for an autonomous okrug - KPAO. ${ }^{156}$ Based on the decree No 196/1-p of the head of KPAO's Administration dated April 29, 2003 - six full months prior to the enlargement referendum, it was obviously designed to facilitate the success of the latter. Governor Saveliev kept the promises to his constituency to lead the okrug to merger with Perm' Oblast' and to invest in economic development.

\footnotetext{
${ }^{155}$ Nikolai Vinogradov, “Osobyi Put' Razvitiya Nesyr'evyh Regionov" (Special Path of Development of the Non-Resource Regions), Nezavisimaya Gazeta No 222 (3335), October 13, 2004

156 "Pasport Programmy Ekonomicheskogo i Sotsial'nogo Razvitia KPAO na 2004-2006 godu i na Period do 2010 goda" (Passport of the Program for the Economic and Social Development of KPAO for 20042006 and till 2010), MERT, April 9, 2004.
} 
The KPAO development program sets the goal of raising of standards of living in the okrug to Russia's average, doubling personal income by 2010 , increasing the GRP 1.5 times and the industrial production 3.6 times (in relation to the 2002 level). The outlined ambitious goals are to be achieved by attracting nine billion rubles in investments, diversification of the resource-based economy, and optimization of social infrastructure. Particular emphasis is made on infrastructural development and diversification. It includes construction of a railroad, gas pipelines, and 84 kilometers of paved and 178.2 kilometers of gravel roads. The diversification of the logging industry of KPAO includes raising the coefficient of timber processing to 60 percent. All these measures are the price of the regional enlargement that the federal government pais to make it possible.

The program, clearly aimed at ensuring the result favorable to the Kremlin's policies, is to create artificial economic growth where, by the laws of free enterprise, there should be none. I argue that the existing logging industry is sufficient, and transfers from the federal budget should sustain the region. Significant investments in the infrastructure and diversification of the economy would cause job losses elsewhere in the greater Perm'. The diversification of logging into timber processing in KPAO is likely to result in shortages of raw materials for the timber processing plants located south of KPAO in Perm' Oblast'. Of the top twenty paper mills in Russia, three are located in Perm'. ${ }^{157}$ Of them, Kamskii Paper Mills already operates below its capacity. Russian paper industry has a scattered character, and investing in processing in KPAO would only increase it.

\footnotetext{
${ }^{157}$ Solikamskbumporm, ranked $8^{\text {th }}$, Kamskii Paper Mills Plant, ranked $18^{\text {th }}$, and Permskii Karton, ranked $19^{\text {th }}$. Mills are ranked by their potential capitalization. "Russkii Biznes - Strategii" (Russian Business - Strategies), Expert, No 48, December 20-26, 2004, at p. 50 .
} 
It is important to bear in mind that much of the industry has been inherited from the USSR: the Russian economy is largely based on the Soviet-built infrastructure and production capacities. Soviet economy always operated as a structure the relationship within which can be described as core-periphery. This relationship still survives. To put it in simple terms, periphery supplied raw materials and finished products to be subsequently distributed across the country by Gosplan. What is often omitted in observations is that periphery has its own periphery, i.e. Perm' and KPAO. Let's call it "periphery of periphery." The relations between periphery and "periphery of periphery" are specific in each case. In case of Perm' and KPAO, there always existed a supplydemand chain. The full chain can be described as a symbiotic relationship of core - to periphery - to "periphery of periphery." In case of timber industry in Perm' and KPAO it would be market - processing - supply of raw material. Bypassing the middle link in this relationship is virtually impossible. If the "periphery of periphery" assumes functions of periphery, it inevitably harms the interests of periphery. Breakup of the existing production - manufacturing - export (to other regions and abroad) chain is undesirable and meaningless. This statement is even more accurate towards an enlarged region, parts of which should work for common goals. They certainly shouldn't compete by duplicating each other.

This example of logging industry in KPAO and Perm' illustrates how the federal center takes an economically irrational step to achieve its political ambition. MERT's program for the development of KPAO till 2010 is motivated by political reasons, and is 
unjustified economically. Investing in diversification of KPAO, MERT acts like Gosplan: by setting illusory goals without regard for the laws of free enterprise.

Following the example of KPAO, U-OBAO has drafted its own economic development plan, which the federal government would have had to adopt if it wanted the okrug to merge with Irkutsk. However, the plan's acceptance did not proceed as smoothly as in the case of KPAO. U-OBAO insisted on investment of 8 billion rubles in the okrug's economy. Most of the money would have been spent on the most important components of its economy - social sphere and development of rural infrastructure. ${ }^{158}$ Thus, the program was not aimed at diversification and covered only the okrug's urgent needs. Irkutsk Oblast' itself, although fully capable to invest in its own infrastructure, followed the example of U-OBAO and drafted an extensive list of demands. They included construction of oncology center, reconstruction of Irkutsk airport landing strip, and return of 15.5 percent of Irkutskenergo (regional energy generation and distribution company) shares from the federation to the region. ${ }^{159}$ Apparently, the federal government did not accept the terms. Otherwise, the enlargement process would have been more synchronized, and would have taken less time.

One of the goals of the enlargement of Tyumen', KhMAO, and YaNAO is possibly also economic diversification. However, unlike in the case of Perm', its aim may be to divert investments from the oil-rich Northern provinces and channel them south to

\footnotetext{
158 “Administratsiya Ust'-Ordynskogo Okruga Vydvinula Uslovia Ob'edineniya s Irkutskoi Oblast'iu” (U-OBAO's Administation has Proposed Conditions of Unification with Irkutsk Oblast ), Regnum News Agency, March 26, 2004 Online at www.regnum.ru/news/237807.html

${ }^{159}$ Mikhail Mazur, "Sliyanie s Ogovorkami: Zakonodateli Irkutskoi Oblasti Soglasny Ob'edinyatsa s Ust'-Ordoi, Na Vygodnykh Usloviah" (Merger with Reservations: Legislators of Irkutsk Oblast' Agree to Unite with Ust'-Orda on Favorable Terms), Rossiiskaya Gazeta, April 23, 2004. Online at www.rg.ru/2004/04/23/ob edinenie.html
} 
Tyumen'. Valery Fyodorov, director of the Center of Political Affairs (Tsentr Politicheskoi Kon'unktury), suggests that enlargement of regions would increase the flow of rents to non-resource part of Tyumen' matryoshka. ${ }^{160}$ Echoing the argument of Hill and Gaddy, he suggests that oil money goes to support of useless infrastructure of towns in the areas where the only population should have been shift crews on the oilfields. Whether this understanding of the purpose of the regional enlargement is meticulously evaluated at the federal level is unclear. However, it is obvious that neither KhMAO nor YaNAO are ready to part with their significant oil revenues without promises of substantial concessions from the center.

Formation of larger constituencies through merger of the small unviable ones with the economically strong is only justified from the standpoint of horizontal symmetry. However, it is only justified in statistical terms. In Russia, where gaps in development are great not only across regions, but also within regions, such balance of constituencies would only mask the great spatial economic disparity of the state. Russia is a country of great inequity, with some small areas experiencing economic boom, and other lagging decades behind.

State-directed artificial diversification of economy resulting from the enlargement of regions would help reach none or few objectives of economic development. Federal incentives in form of investments are temporary. They would only sustain economies of

\footnotetext{
160 "Kontrolirovat' Vsu Territoriu" (Control All the Territory), News Service Gazeta.Ru, May 28, 2003. Online at www.gzt.ru
} 
the poor regions for the duration of enlargement process. Thereafter, the richer parts of the merged region would have to assume the burden of sustaining the poorer economies.

\section{Federal Incentives for Merger as Means to Enhance Connectivity of Russia}

In addition to stimulating diversification in regional economies, the regional enlargement projects are designed to enhance the connectivity within regions - between production, manufacturing, and consumption zones, and with the rest of the country. By connectivity I imply the connectivity of areas of spatial development to which these zones are confined within regions.

Attempts to connect the outlying provinces of Russia have been made since the exploration and conquest of Siberia. First, military outposts were established in the new territories. Later, some roads and railroads were constructed. Some of the most notable ones include the Siberian Tract (Sibirskii Trakt) constructed by Catherine the Great in late eighteenth century, the Trans-Siberian Railroad constructed by the last Russian Tsar Nicholas the Second in early twentieth century, and the BAM (Baikalo-Amurskaya Magistral') completed in the Soviet period. These and other smaller transportation corridors have linked European Russia with Siberia and the Far East, and serve as major economic engines for the Eastern and Northern Russian regions. 
Twenty-first century Russia needs new transport corridors in most regions. Like any other state, it needs new highways, bridges, pipelines, and power lines. These new corridors are needed to connect the country and not to connect spaces within regions. I suggest that the policies of regional enlargement are aimed at enhancing the connectivity of the state as a whole, and not at diversification of economies and stimulating economic growth.

The vital role connectedness to the infrastructure can play in economies of remote regions may be inferred from Scheme 4 (p. 168). The budgetary flows between the Federation and the Siberian FD depict its clear division into donor and recipient regions (donor-recipient relations are discussed in more detail in the next chapter) Irkutsk Oblast' along with five other regions is a donor receiving back less than a quarter of the taxes it transfers to the federal budget. U-OBAO along with nine other regions is a recipient receiving almost three times as much form the Federal budget as it contributes. An interesting observation can be made about the types of donor and recipient regions in the Siberian FD. All six donors are regions with administrative-territorial boundaries oblasts and krais; eight of the ten recipients are regions with ethno-territorial boundaries, each containing a titular ethnicity - republics and AOs. However, their territorial characteristics hardly determine their status of donors of recipients.

The oblasts and krais were originally established as larger territorial units than most of the autonomous okrugs. They are located on the resource-abundant territories. However, resource abundance alone is useless in such a remote area without developed 
infrastructure. Production sites should be connected with the refining and manufacturing centers, and major roads, railroads, and airports are located in the donor regions. Recipient regions of the Siberian FD have to rely on the donors for their economic transit needs of people, resources, products, and capital.

Lack of connectivity may indeed be an obstacle to growth in some regions. At the same time, the establishment of infrastructural links between the underdeveloped and developed regions may be a measure short of solving the economic problems of the poor regions and diversification of their economies. The short-term benefits of enhanced connectivity are limited, as most of the needed infrastructure already exists (connection of core with "periphery of periphery" is inexpedient). The long-term benefits of the update and reconstruction of the existing infrastructure and the construction of new links may enhance the economic well-being of some areas in the process of development of path dependency evident in the example of the Siberian FD.

However, I believe the connectivity argument is too weak to justify regional enlargement. As I have stated previously, connectivity does not require merger of regions. On the opposite, its enhancement renders the enlargement process useless. There are two negative scenarios of the implementation of the federal-sponsored new infrastructural projects. They can be insignificant to produce the declared effects on regional economy, like the construction of 178.2 kilometers of gravel roads in KPAO. They can also fail to produce the desired effect if they are aimed at fostering economic growth in places where it is impossible or costly to do so. Large infrastructural projects 
may impede the stimulus of people to relocate from the Far North. Moreover, they can attract people to cold and remote areas where the cost of living and production would always be extremely high compared to areas in Western and Southern Russia. Thus, such projects may artificially sustain the otherwise unsustainable economies, and the Russian government may be doomed to repeat the mistakes of Gosplan.

I believe, that among the three cases of enlargement only KhMAO and YaNAO actually require new infrastructure. It should link new oilfields directly to the City of Tyumen' in the south. As a result, crews employed at the oilfields would be able to live in the south, and slowly "drain" the population of the West Siberian oil cities. New infrastructure may save Tyumen' from shrinking and contain unnecessary investment in the social infrastructure of the north.

Tyumen' Oblast', the host region for KhMAO and YaNAO in the Soviet times, has been gradually losing its dominant position in the region to KhMAO and YaNAO since late 1960s. Since the breakup of the USSR, KhMAO and YaNAO have established their independent governing structures. At the same time, as the privatized oil and gas companies consolidated their positions, they have been moving their headquarters to oil towns in the AOs and to Moscow, bypassing the City of Tyumen', the capital of Tyumen' Oblast', as an intermediate administrative center. ${ }^{161}$

There are two primary reasons why Tyumen' is being bypassed. First, it has lost its role as the capital of the greater region when KhMAO and YaNAO claimed equal

\footnotetext{
${ }^{161}$ This is another example of how the scheme of "core-to periphery-to periphery of periphery" is broken.
} 
status of the subjects of the Federation. Second, oil revenues have enabled the AOs to build up their economies and invest in their regions. Large investments outside the oil and gas industry have been made into the infrastructure of the oversized Northern cities. ${ }^{162}$ Inherited from the planned economy, they require continuous maintenance. Recently acquired social problems like AIDS and drug abuse force the okrug governments to invest even more in the social infrastructure - hospitals, schools, activity centers - all of which could have been built at warmer and less remote locations. In an enlarged region, this might be possible.

\section{TRENDS OF FISCAL FEDERALISM: SHIFTING THE BUDGETARY BURDEN TO REGIONS}

Following this logic of the masterminds of the regional enlargement, it may be concluded that the sum of two economies creates a bigger single economy. However, this assumption may be false. The economy of one of the merging regions may be depressive and loss-making, while the economy of the other(s) merging region(s) may be very prosperous. When two economies are summed up, they do not necessarily benefit each other, unless their merger indeed provides for greater diversification of the larger economy. The prosperous region may not produce a significant wave effect on the depressive region as the study of Expert Magazine scholars has demonstrated (see the first section of the chapter on economy). It is hard to imagine how merger can facilitate this. The depressive (poor) region may in fact slow down the otherwise healthy economy of the prosperous (rich) region. Greater economy may absorb the shock of merger, but,

\footnotetext{
${ }^{162}$ KhMAO's governor Aleksandr Filipenko boasted to President Putin that at present he has "a unique opportunity to develop high-quality social infrastructure." Vladislav Vorobiev and Oleg Galitskih, "Luchshe Vy k Nam na Sever" (You Better Visit Us in the North), Rossiiskaya Gazeta, August 18, 2004. Online at www.rg.ru/2004/08/8/vstrecha.html
} 
unless the poorer economy improves on its own or with the help from the federal government, the economy of the prosperous region may have to perpetually subsidize the depressive economy in ways the federal government had been doing between the parade of sovereignties and the present.

Evidence of the notion that the sum of two or more regional economies does not necessarily lead to growth in either of the two economies may be found by analyzing the structure of federal-regional budgetary relations of the merging regions. Typically, large federations have steady donors and steady recipients among their multiple constituencies. In federations, the function of intergovernmental redistribution of resources and maintenance of budgetary balance is usually assumed by the federal center. ${ }^{163}$ Steady donors are regions with relatively strong economies, which usually give more money to the federal government than they receive from the federation to balance their budgets and for other purposes (grants, aid, loans, donations). Steady recipients, on the opposite, are regions with weaker economies, which are dependent on transfers from the federal government to maintain their budgetary balance.

Russian federal-regional budgetary relations demonstrate the above-described pattern. In Soviet times, horizontal transfers were masked by the command economy. The last fifteen years of Russia's existence as a federation "under construction" have clearly exposed the disparity of incomes in regions and identified the steady donors and recipients of federal transfers.

${ }^{163}$ Alastair McAuley, 1997, p. 439. 
Table 8 (p. 127) shows the balance of some of the Russian regions in terms of financial aid. While Perm', Tyumen', and Irkutsk Oblasts were steady donors in the period between 1995 and 1999, small AOs like KPAO and U-OBAO have been steady recipients. Other "traditional" donor regions include the City of Moscow as well as the oil provinces of KhMAO and YaNAO. The disparity among the regions has only increased since the rise in commodity prices in 2000 . While the donors have further solidified their positions among Russian regions, most of the recipients have only experienced more downturn. Also, the population of the steady recipients constitutes only 7.5 percent, and of the steady donors over 80 percent of the total Russian population, which supports the demographic argument for enlargement.

The table demonstrates that the merger of donors like Perm' and Irkutsk with recipients $\mathrm{KPAO}$ and $\mathrm{U}-\mathrm{OBAO}$ may be well justified. It may relieve the federal government from subsidizing the latter regions by transferring this obligation directly to donors.

Table 8. Donor Regions and Recipient Regions in 1995-1999

\begin{tabular}{|c|c|c|}
\hline Steady Donors & Donors in Some Years & Steady Recipients \\
\hline $\begin{array}{c}\text { Population } 117.7 \text { million people }(80.7 \%), \\
\text { including: }\end{array}$ & $\begin{array}{c}\text { Population } 17.2 \text { million people } \\
(11.8 \%)\end{array}$ & $\begin{array}{c}\text { Population } 11.0 \text { million people } \\
(7.5 \%)\end{array}$ \\
\hline $\begin{array}{c}\text { Perm' Oblast', Tyumen' Oblast', Irkutsk } \\
\text { Oblast', KhMAO, YaNAO, City of Moscow }\end{array}$ & -- & KPAO, U-OBAO \\
\hline
\end{tabular}

Source: Federal Budget and Regions: Structure of Financial Flows (Federal'nyi Budjet i Regiony: Struktura Finansovykh Potokov), East-West Institute (Instityt "Vostok-Zapad). Moscow, MAKS Press, 2001. Online at http:/www budgetrf ru/Publications/Analysis/iews/an jews 120902/an iews 120902000.htm

The contrast between the donors and the recipients is even more obvious from the calculations of financial giving and aid per capita (see Table 9, p. 128). The following 
table puts Perm' and Tyumen' Oblasts and the oil provinces of KhMAO and YaNAO in the category of regions that contribute more than 2,000 rubles per capita (in 1999) as aid to other regions. Irkutsk Oblast' contributes between 1,000 and 2,000 rubles per capita. At the same time, KPAO receives aid of up to 1,000 rubles per capita, and U-OBAO receives over that amount.

\section{Table 9. Typology of Regions by Volume of Balance (by financial aid) calculated per capita, in 1999}

\begin{tabular}{|c|c|c|}
\hline $\begin{array}{l}\text { Indicator, rubles per } \\
\text { capita }\end{array}$ & $\begin{array}{c}\text { Population, Million People (Share of } \\
\text { Russia's Population, \%) }\end{array}$ & Including Regions: \\
\hline $\begin{array}{l}\text { Region Contributes more } \\
\text { than } 2000\end{array}$ & $39.0(26.7 \%)$ & $\begin{array}{l}\text { YaNAO, KMAO, Perm' Oblast', Tyumen' } \\
\text { Oblast', City of Moscow }\end{array}$ \\
\hline $\begin{array}{l}\text { Region Contributes from } \\
1000 \text { to } 2000\end{array}$ & $52.3(35.9 \%)$ & Irkutsk Oblast' \\
\hline $\begin{array}{l}\text { Region Contributes up to } \\
1000\end{array}$ & $40.8(27.9 \%)$ & Republic of Tatarstan \\
\hline $\begin{array}{l}\text { Region Receives up to } 1 \\
000\end{array}$ & $8.5(5.8 \%)$ & KPAO \\
\hline $\begin{array}{c}\text { Region Receives over } \\
000\end{array}$ & $5.3(3.7 \%)$ & U-OBAO \\
\hline
\end{tabular}

Source: Federal Budget and Regions: Structure of Financial Flows (Federal'nyi Budjet i Regiony: Struktura Finansovvkh Potokov), East-West Institute (Instityt "Vostok-Zapad), Moscow, MAKS Press, 2001. Online at http/www budgetrf.ru/Publications/Analysis/iews/an_icws_120902/an iews 120902000.htm

Thus, pairs of merging regions - Perm' and KPAO and Irkutsk and U-OBAO are asymmetric within their matryoshkas. In 1999 Perm' Oblast' contributed more than 2,000 rubles per capita while KPAO received up to 1,000 rubles per capita. Similarly, while Irkutsk contributed between 1,000 and 2,000 rubles per capita, U-OBAO received over 1,000 rubles. Of course, as I have indicated in the section on demographics, the populations of these two oblasts and two autonomous okrugs are drastically different. For example, while KPAO's population is only five percent of Perm' Oblast's population, it receives at least half of what the Oblast' contributes per capita. These figures testify how 
poor KPAO is in relation to Perm'. This population disparity makes asymmetry among the regions even greater.

The above-described statistical approach strongly supports merger of large donor oblasts with small recipient AOs. Merger of Perm' and KPAO creates a region that would statistically fall under category of "steady donor" or "donor in some years," and remove one region (KPAO) from the category of "steady recipients." However, the declared goal of the regional enlargement is not to create more symmetry in statistical terms. In fact, merger only slightly alters the inter-budgetary flows. The volume of money in the Federation or in a given region does not change. Since late 1990s, the federal budget has been allocating about 14 percent of its volume as aid to subjects of the federation (regional budgets). In 2004, the number stood at about 15 percent of the Russian federal budget. ${ }^{164}$

There is no evidence that money would be distributed in a fairer way through a budget of an enlarged region. Similarly, there is little evidence that fiscal centralization translates into fair redistributive policies. ${ }^{165}$ Therefore, enlargement doesn't necessarily

\footnotetext{
${ }^{164} 813,969,815,6$ thousand rubles of the total Russian Budget, 2004, was 2,400,751,227,2 thousand rubles. "Prilozhenie 21 k Federal 'nomy Zakony "O Federal'nom Budjete na 2004 God," Raspredelenie assignovanii iz federal 'nogo budjeta na 2004 god po razdelam i podrazdelam., tselevym statiyam i vidam raskhodov fynktsional'noi klassifikatsii raskhodov budjetov Rossiiskoi Federatsii" (Appendix 21 to the Federal Law "On the Federal Budget for Year 2004", Allocation of the Resources from the Federal Budget for year 2004 by Articles and Sub-articles, Special Purposes, and Types of Expenditures of the Functional Classification of the Expenditures of the Budgets of the Russian Federation ), Online at www. budgetrf.ru

${ }^{165}$ According to a 2004 VTSIM Survey, as many as 82 percent of Russians, including the Muscovites, believes that the City of Moscow lives at the expense of the other regions of Russia. "Moskva I Moskvichi: Vzglyad iz Rossii" (Moscow and Muscovites: View from Russia), VTSIOM, Press-Release No 113, September 3, 2004.
} 
alleviate the economic problems of poor regions. Rather, it hides pockets of poverty within greater and statistically prosperous regions. ${ }^{166}$

Enlargement of Tyumen' Oblast' presents a different case. All three of the subjects proposed for enlargement are the leading donor regions in the Federation, with Tyumen' Oblast' lagging a little behind the autonomous okrugs in recent years. The merger of Tyumen' would have resulted in the formation of an even greater region, which would have further skewed the horizontal asymmetry among Russian regions. Its gross regional product (GRP) would have been second only to Moscow's in absolute terms. The region would have ranked first in terms of per capita GRP in Russia (see Table 10, p. 130).

\section{Table 10. Economic Indicators of the Studied Regions: Possible Changes after Proposed Mergers}

\begin{tabular}{|c|c|c|c|c|}
\hline Region & $\begin{array}{l}\text { GRP, millions of } \\
\text { Rubles, } 2002^{\wedge}\end{array}$ & $\begin{array}{l}\text { Income Per } \\
\text { Capita, } \\
\text { Thousands of } \\
\text { Rubles } 2003^{*}\end{array}$ & $\begin{array}{l}\text { Income Per } \\
\text { Capita, Moscow } \\
=100 \% \%^{* *}\end{array}$ & $\begin{array}{c}\text { GRP per capita, as a } \\
\text { share of average } \\
\text { Russian GRP per } \\
\text { capitat, } \%\end{array}$ \\
\hline Perm' Oblast' & 191449.4 & 60.55 & $19.76(20)$ & 91 \\
\hline Komi-Permyatskii AO & 2905.7 & 20.85 & $2.07 \quad(85)$ & 28 \\
\hline $\begin{array}{l}\text { Perm' and KPAO } \\
\text { (Permskii Krai) }\end{array}$ & 194355.1 & & & \\
\hline 'Tyumen' Oblast' & 98912.9 & 124.88 & $48.42 \quad(4)$ & 73 \\
\hline Khanty-Mansiiskii AO & 581777.0 & 154.43 & $61.59 \quad(3)$ & 331 \\
\hline Yamalo-Nenetskii AO & 279355.6 & 193.17 & $78.85 \quad(2)$ & 444 \\
\hline $\begin{array}{l}\text { Tyumen' Oblast', KhMAO and } \\
\text { YaNAO }\end{array}$ & 960045.5 & & & \\
\hline Irkutsk Oblast & 145818.4 & 50.76 & $15.40 \quad(28)$ & 74 \\
\hline Ust'-Ordynskii AO & 3794.8 & 16.96 & $0.34(86)$ & 39 \\
\hline Irkutsk Oblast' and U-OBAO & 149613.2 & & & \\
\hline \multicolumn{5}{|l|}{ Other Regions } \\
\hline Republic of Tatarstan & 261843.9 & 50.53 & $15.29(29)$ & 87 \\
\hline Republic of Chechnya & No data, very low & $<16.21$ & $\mathrm{n} / \mathrm{a},(88$ or 89$)$ & no data \\
\hline City of Moscow & 1999995.3 & 240.63 & $100.00(1)$ & 241 \\
\hline
\end{tabular}

$\wedge$ - GRP in 2004 market prices, GosKomStat, 2002 http:/www.gks.rulbgd/free/b01_19//swPrx.dll/Stg/d000/i000480r.htm

* - AK\&M Rating Center, http $/ /$ www.akm, ru/rus/rc/roks 040527.stm

** - Rating among Russian regions in parenthesis

$\dagger$ - Average Russian GRP per Capita in $2004=90,45$ thousands rubles

\footnotetext{
${ }^{166}$ See discussion and references in subchapter on Mergers of Regions as Mergers of Capital Cities, p. 29-30.
} 
The existing system of fiscal federalism is largely possible through hthe mechanisms of redistribution of resource rents. The federal enlargement policy is based on a system of incentives. I characterize it as a system of "carrots and sticks" of federalism. For the poor regions, "carrot" comes in form of federal investments in regions in case of their enlargement. "Stick" implies the continuation of the current federal policies when regions with little bargaining power at the federal level hardly receive anything from the center except for transfers to balance regional budgets. For the rich regions, "stick" represents tighter fiscal regime, under which donors are forced to contribute greater shares of their incomes to the federal budget. The "carrots" of regional enlargement, which come in form of development aid (primarily infrastructural projects to enhance connectivity described in previous chapter), are the result of Russia's newly found oil wealth. The federal government is strengthening fiscal federalism by coercive methods. In addition to reclaiming taxes from production companies (YUKOS), oil rents $(N D P I)$ are being reclaimed from regions. With rents and other taxes filling the federal coffers, the government is able to manage redistributive policies better, and to use the super-profits to manipulate regions. This process has touched the enlargement of regions, where the state deploys both "carrots" and "sticks." Once the rich (donor) regions are subdued into compliance with the fiscal policies, federal revenues steadily increase. With the increased disposable tax revenues, the state can easily influence the poor (recipient) regions, which would be least tempted to pursue policies centrifugal to the Federation since their economic well-being is dependent upon the state and/or the state's relations with the rich regions. I suggest this compliance of the poor regions enables the federal 
government to tighten its control over constituencies and nominally enhance the horizontal symmetry of the state.

Horizontal symmetry can be achieved in the short-term by two policies. First, it can be enhanced through federal redistributive policies given that there are federal revenues to draw from. Second, it can be enhanced through the enlargement of regions, particularly if the rich regions are grouped with the poor (steady donors are grouped with steady recipients). As the poor autonomous okrugs continue setting precedents of enlargement, and it seems it wouldn't be long until poor regions of oblast' status begin to merge.

Indeed, if merger brings together the rich and the poor subjects of the Federation, their budgets merge, and some of the taxes collected in one richer part of the greater region become available for the other poorer part. Thus, regions would retain a greater share of taxes, and the federal government would have fewer redistributive functions. In theory, regional enlargement is a scheme for industrialized and/or resource-based economies to subsidize poor and underdeveloped (usually agricultural) economies without obvious involvement of the state. The extent to which the different economies of merging regions would integrate depends on regional economies themselves. The conditions created by the federal government for the enlargements of regions - greater regional economic diversification, enhanced connectivity, and budget deficit balance are temporary and superficial solutions. Their alleged positive effects have not been tested, and would probably be offset by the perpetual characteristics of the Russian 
economy - manufacturing centers in cold climate and geographic location of resource deposits.

\section{ECONOMIC FACTOR IN THE ENLARGEMENT OF REGIONS}

Assessing the economic aspect of federalism, Watts suggests that the "changing nature of federal relationships can undermine the stability - at least relative to unitary systems - that is often necessary for a united and productive economy., ${ }^{167}$ However, this statement might be accurate only for federations at their very early formation stages. Although Russia is a new state, its territories retain a number of economic ties, not limited to communications and transportation. In many respects, Russian regions are interdependent.

I argue that Russia's economic performance can hardly be enhanced on the regional level as a result of enlargement. Creation of larger regions would eliminate a few administrative barriers, which are essentially minor inconveniences for the economy. Any volume of investment committed to the development of regions by the federal government would only marginally be related to their merger. The scale of Putin's plan of economic integration into a single economic space, like the plans of all of his predecessors, is not limited to "conquest" of a few eastern or northern regions. Rather, his

\footnotetext{
${ }^{167}$ Watts, 1996, p. $99-100$.
} 
vision of Russia is primarily that of a connected state. In this sense, the goal of balanced regional development is secondary. ${ }^{168}$

Connectedness of space implies the task of greater control over Russia's vast Eurasian territory. The aspect of regional enlargement in this grandiose scheme may become a major contributing factor of economic integration and prosperity only if it is successfully undertaken on a larger scale. If this assumption were true, all small and poor regions would be "devoured" in this great scheme; their bad economic performance masked in the greater regions.

In the Urals and beyond, Putin's and his successors' greatest enemy would still be the cold and the distance, not the number of political and economic units or even the degree of diversification or monopolization. ${ }^{169}$ The economy of the studied regions will be affected very marginally as a result of mergers. The promised infrastructural projects would serve to connect Russia rather than parts of the merging regions. Roads, bridges and pipelines are built to connect people and places, the production sites with manufacturing, consumption, and export centers. ${ }^{170}$ On the one hand, these projects are implemented with the long-term goal of overcoming disastrous miscalculations of the Soviet planned economy. On the other hand, however, their implementation alone cannot significantly stimulate depressive regional economies unless other plans for economic

\footnotetext{
${ }^{168}$ In other words, the logic is as follows: first, Russia's GDP should be doubled in one decade; then more harmonious growth would take hold. This Gosplan-style approach to creating the illusion of growth in economies of scale can hardly provide for sustainable economic growth.

${ }^{169}$ See a major recent work on this subject, Fiona Hill and Clifford Gaddy, The Siberian Curse, 2003.

${ }^{170}$ See, for example, "Vision for the Northeast Asia Transportation Corridors," Transportation Subcommittee, Northeast Asia Economic Conference, Full text of the report online at http:/www.erina.or.jp/En/Lib/Bl/PDF/bl1-e.pdf and E. Boze, A. Fedkin, N. Trunova, D. Yalov, A. Zheltov, "Topical Analysis: Why Does Russia Need a Concept of Spatial Development? Spatial Development of Russia," Russian Expert Review No 10, online at http://www rusrev,org/BlazeServer/page.jsp?pk=node 1082024278657
} 
revitalization and build-up are undertaken. The increasing level of state involvement in the economy already resembles the pre-1991 Gosplan system. Enhancement of connectivity does not require regional enlargement. Russia's internal ethno-territorial and administrative-territorial boundaries are nominal in terms of constitutional provisions for the economy.

On the surface, the enlargement of regions eliminates only minute, if any, administrative barriers. Therefore, the policy of incentives in form of federal grants and infrastructural projects is but a trap for the regional elites to make power concessions to the federation and to the enlarged regions, which would supposedly be easier to govern and control from the capital. Being an independent subject of the Federation is a high constitutional status. Its permanent loss is incomparable to the one-time economic incentives, which themselves are questionable. 


\section{SUMMARY AND CONCLUSIONS}

There are some similarities and some differences among the three studied regional enlargement cases. There are a few notable patterns of regional enlargement that are worth noting in this summary of demographic, political, and economic similarities and differences of the three cases based on the discussions and findings of the previous chapters.

\section{Demographics}

All three cases involve merger of sparsely populated subjects of the Russian Federation with more populous ones. In all three cases, the more sparsely populated subjects are autonomous okrugs. However, all the studied constituencies have experienced net population decline over the last fifteen years. Since the population decline is likely to continue, enlargement is a temporary means to statistically justify the existence of regions and enhance horizontal federal symmetry. The argument for efficient governance may be applicable to cases of Perm' and Irkutsk. Other similar cases of enlargement are to follow. Tyumen', if merged with AOs, would clearly become an oversized region like Krasnoyarskii Krai has upon its enlargement in April 2005. 
As a consequence of regional enlargement, the titular ethnicities of autonomous okrugs lose their ethno-territorial distinction at the federal level, but retain administrativeterritorial status at municipal level. They either become minorities (Komi-Permyaks in Permskii Krai) or even lose the status of double-minority (Buriats in enlarged Irkutsk Oblast', Khanty, Mansi, and Nenets in enlarged Tyumen' Oblast ').

Regional enlargement is an easier process in regions dominated by one or few oversized cities. The phenomenon of "merger of regions as merger of capital cities" is most visible in Perm', less obvious in Irkutsk, and is not applicable to Tyumen'. The demographic factor builds a somewhat strong case for political and economic justification of regional enlargement - both for sparsely populated and poor regions, and for sparsely populated but rich regions with high GRP per capita. However, population size is not utilized by the federal and regional governments as rationale for enlargement.

\section{Politics}

I assess the regional enlargement as a political process. Although it has been confined to few specific cases involving oblasts and autonomous okrugs, it may yield actual results before the next Russian presidential elections in 2008. Its outcome will be tested in the near future in Permskii Krai, Krasnoyarskii Krai, and, possibly in Koryakskii $A O$ and Kamchatka Oblast'. Based on the conducted research, I conclude that politics are central to the process of enlargement. Economics and demographics may only serve as auxiliary arguments of the enlargement political campaigns. 
Enlargement of regions is a top-down process orchestrated by federal and regional political elites. Their cohesion among each other is highly important. I have used the case of Perm' as the only successful enlargement experiment and compared its experience with two other cases. This allowed me to understand the mechanism of successful enlargement and to determine what possibly went wrong and slowed down the political process in other cases. To be successful, the enlargement process required the will of the elites. It also required synchronized political action - in administrative decision making in the executive branch and in adoption of relevant legislation in the Russian Duma and in the regional parliaments. In addition, enlargement initiative campaigns constituted an important part of enlargement. To yield a yes-vote for merger, it was preferable that campaigns were supported by a wide spectrum of religious, national (ethnic), and political leaders and groups.

Enlargement of regions in all three cases is aimed at "containment" the aspirations of ethnic minorities for their ethno-territorial federal units. It prevents Komi-Permyaks from joining the Komi Republic, Nenets from the formation of a single Nenets constituency across the three AOs, and Buriats from establishing a unified and independent Buriat Republic. The enlargement is aimed at depoliticizing the ethnic factor in the Russian state-building by creating larger multiethnic constituencies, in which titular ethnicities (of the AOs) would be diluted. Eventually, the enlargement of matryoshkas may not only enhance the horizontal symmetry in the Federation, but also contain ethnic republics. Thus, abolition of autonomous okrugs may also enhance the 
vertical symmetry by creating regions of equal status regardless of their name - oblast', krai, or republic.

\section{Economy}

The analysis of the economic component of the regional enlargement in Perm', Irkutsk, and Tyumen' has yielded mixed results. However, all three cases have displayed a pattern of federal strategy of enlargement. In an attempt to make the federation more symmetrical by merging regions into self-sufficient entities, the federal government has adopted a policy of incentives - carrots and sticks. While I argue that the ultimate goal of the federal government is to enhance the connectivity of Russia as a whole and to stimulate the diversification of economy at the regional level, some rationale for enlargement may exist from the standpoint of regions as well.

In the case of Permskii Krai, the enlargement creates an economic burden for Perm' but constitute an economic necessity for KPAO. While federal incentives are given to both subjects, KPAO, as one of the poorest subjects of the Federation desperate for investment, agreed for merger. Possibly, people in Perm' voted for merger out of their solidarity with the Komi-Permyaks, and true hopes to create more equity in the greater region. A similar pattern is obvious in the case of Irkutsk Oblast' and U-OBAO, where the single main obstacle to enlargement is the amount of federal economic incentives. 
The economic, as well as demographic and political, aspect of the enlargement of Tyumen matryoshka is different from Perm' and Irkutsk. While it may be perceived as a political ambition for Tyumen', rich AOs appear to be unmotivated to pursue the enlargement. As the federal government centralizes rents, it competitively gains more bargaining power vis-à-vis the resource-rich okrugs. To facilitate enlargement, it may offer federal tax incentives to the okrugs in the near future.

The argument for diversification of economy doesn't hold. Diversification of economies may create bigger economies, but manufacturing industries should not be moved north to the autonomous okrugs because of inefficiency of operation in colder and disconnected areas. Even merged economies would remain polarized in their production or processing/manufacturing orientation. In terms of enhancement of the connectivity of Russia, enlargement of regions is also a useless process. Federal infrastructural projects don't require moving the administrative boundaries.

Finally, the system of fiscal federalism exists to balance the earnings and expenditures of budgets in the system. The federal government promises investments in exchange for regional enlargement. However, the volume of money in the state remains the same, and much needed investments can be made without enlargement. Masking the poorest regions like KPAO and $\mathrm{U}-\mathrm{OBAO}$ in greater regions would statistically enhance the horizontal symmetry. Enlargement of Tyumen' only exacerbates the asymmetry, and will probably be reconsidered. 


\section{CONCLUSIONS}

The study of some aspects of regional enlargement in the Russian Federation has demonstrated how the poorest regions are being convinced to cede their federal status in exchange for some unclear promise of socioeconomic prosperity. The desired affect is achieved through a policy of federal incentives offered in form of minute infrastructural investments. The federal government can afford to offer them as a result of the continuous oil boom and increased fiscal burden on oil producers and exporters. The federal government is likely to speed up the process of regional enlargement to make sure it is complete while the windfall oil profits last. Also, the poor constituencies may realize that the benefits that regional enlargement brings are temporary incentives which do not facilitate improvements in their long term socioeconomic status, and, therefore, are not worth the loss of their federal (constitutional) status.

Regional enlargement starts with matryoshka subjects, gradually abolishing a whole tier of ethnically defined federal units. Mergers complement the ongoing administrative reform (Kozak's Reform). They are the direct result of a combination of federal policy of financial incentives in areas of more redistributive (symmetrical) fiscal federalism and infrastructural projects for the enlarged regions. However, based on the fact that regions merge as a result of free expression of the people's rights in regional referendums, the enlargement is portrayed as a bottom-up process in state media.

The newly created regions are most likely to take the form of oblasts and krais the most common forms of Russian federal territorial division. The federal government 
will not allow for the formation of new (ethnic) republics in Russia. On the opposite, the number of ethnically defined subjects of the Federation - autonomous okrugs - will decrease. Ethnic minorities compactly residing in autonomous okrugs would be effectively excluded from direct participation in the federal political process in Russia as a result of enlargement. Moreover, their representation would be diluted at the regional level as well. Their ethnic (national) territorial autonomy would be replaced with cultural autonomy. The okrugs would be reduced in status from constituencies in a federal system to ethnically defined administrative-territorial municipal units. ${ }^{171}$ The bargaining power of former autonomous okrugs would dramatically decrease.

The enlargement of regions through incorporation of small ethnically defined regions and the formation of larger regions would give more bargaining power to the latter. However, the new regions will not border foreign countries and their ethnic minorities will be diluted by ethnic Russian and other nationalities, which, unlike the small aboriginal populations of the autonomous okrugs, may have their ethnic republics elsewhere in Russia or in the "near abroad."

In the long run, the federal government plans to delegate more authority for protection of small minorities to larger regions with ethnic Russian majorities. This shift may take place should the new federative units become financially self-sufficient, and their administrations remain loyal to the Kremlin and compliant with the federal legislation. However, if necessary, the federal government would retain its right to

\footnotetext{
${ }^{171}$ According to article 12 of the Russian Constitution, bodies of (cultural) municipal self-government are excluded from the two-tier system of state (federal and regional) government.
} 
interfere in regional ethnic policies. As long as the article 72-1-b of the Russian Constitution is not amended, "ensuring the rights of ethnic minorities" would remain an area of joint jurisdiction of the federal and regional governments.

Also, major infrastructural projects currently undertaken by the federal government as part of regional development and enlargement programs will enhance the connectedness of the state. The new enlarged regions would not only become more integrated internally, but also with neighboring regions and the state as a whole. In the 1990s, rich regions were relatively independent politically and economically and were unchecked by the federal government. Poor regions, having won federal status and become politically independent, developed heavy dependency on federal government for subsidies, subventions, and grants. The enlarged regions create a new form of dependence, by which the poor municipalities reduced in their status through merger become more dependent on their rich regions. The latter, in turn, would develop greater interdependence with neighboring regions and the Federation. These ethnic, political, and economic factors combined would minimize chances of secession of the enlarged regions from the Federation.

The Russian Federation may become more centralized and interlinked. Enhanced economic exchange would help integrate the horizontal socioeconomic ties, and make them individually less economically dependent on the federation. "Economic connections are essential for real political connections to develop." ${ }^{, 72}$ However, since late 2004, regional connections at governors' level develop under federal supervision. The institute

\footnotetext{
${ }^{172}$ Hill and Gaddy, 2003, p. 116.
} 
of polpreds and the procedure of appointment of governors contain the horizontal symmetry across the regions at economic level. Politically, the system of governance is formed from the top down. "Vertical of power is being freed of any "architectural extravagancies' and is streamlined perpendicularly upwards." ${ }^{, 173}$ Dilution of a number of ethnic minorities, the "proliferation" of United Russia centrist party at the executive and legislative regional levels, and autonomization (coupled with reduction in status) of local self-governance secure greater federal control over important regional affairs. Vertical symmetry is skewed towards the federal government, signifying the transition from a loose federation to a more centralized one.

\section{Federal Symmetry}

A degree of asymmetry is a feature of all federated states. In large and cold Russia the distribution of people and resources is destined to perpetually induce horizontal asymmetry despite administrative-territorial reorganization. Even as a unitary state, Russia will remain asymmetrical in terms of West-East and North-South. The critical factor of Russia's federal symmetry is the distribution of political power. In the end, it is not geography, geology, or population, but the division of power that provides for a federative state. From what my study has demonstrated, at least in the near future, the enlarged regions would receive some preferential treatment from the federal center, but will not assume additional political functions other than those of administering larger

\footnotetext{
${ }^{173}$ Yekaterina Dobrynina, Rossiiskaya Gazeta, March 6, 2004.
} 
territories. On the opposite, the enlarged regions may partially lose their representation in the Russian Legislative Chambers.

As of August 2005, it is impossible to predict the full political disposition the regional enlargement would entail. As a process, can be assessed from the standpoint of federal symmetry, which sheds light on the extent of the Kremlinization of Russia and the validity of the economic argument for the regional enlargement.

It would be impossible to maintain horizontal federal symmetry in terms of area and population size due to Russia's geographical constraints. However, the policy of regional enlargement is capable of partially solving the unequal distribution of oil, gas, and other deposits. It is no longer a taboo to refer to the resource-related industries as to the primary drivers of Russia's stability and economic solvency. A more balanced fiscal policy may facilitate fairer distribution of state-owned resources, but it is unlikely to serve as a sole guarantor of the future economic growth of poorer regions.

In terms of vertical federal symmetry, given the new law on the appointment of governors, functioning of the institute of polpreds, and the allocation of taxes, the federal government is likely to gain more power vis-à-vis regions. This power would create greater vertical asymmetry. Harmful to federation as a system of political organization, it may be useful for the central government's negotiations on the status of Chechnya and the other twenty republics. 
With the disappearance of most or all ethnically defined autonomous okrugs from the political map of the Russian Federation, the multinational dimension of federal politics would be easier to assess and may allow the federal government to route more of its administrative and financial resources to the ethnicity-related issues which endanger not just the symmetry of the state, but its security and integrity. The vertical symmetry would, therefore, be skewed to the advantage of the federal government. Should all autonomous okrugs indeed cease to exist as federal units in the next three years, President Putin and his team spearheaded by Dmitry Kozak should be given credit for their ability to openly implement a significant part of the administrative reform without amending the Constitution and maintaining and preserving the state. As Vyacheslav Nikonov, the president of Politika (Politics) Fund puts it, "Putin's strategy is not autocentrism (autocracy) or anarchy, but a functioning and effective democracy under the unchangeable Russian Constitution." ${ }^{174}$

Regional enlargement is a process which may facilitate formation of a strong democratic state or a strong authoritarian state. Both regimes would secure the rule of law, but through sets of very different mechanisms. Unless Russia becomes a more symmetrical Federation in terms of political power and economy (including fiscal federalism), it is more likely to embark on an authoritarian path of development. If vertical asymmetry decreases, and horizontal symmetry enhances, Russia is more likely to form a strong democratic state.

\footnotetext{
${ }^{174}$ Vyacheslav Nikonov, "Strategiya Putina. Stremlenie Predotvratit' Raspad Gosudarstva Lezhit v Osnove Federal'noi Politiki" (Putin's Strategy. Aspiration to Preclude the Breakup of the State is the Foundation of Federal Policy), Rossiiskaya Gazeta, December 22, 2004, Online at www.rg.ru/2004/12/22/putin-strategia.html and http://www.polity.ru/articles/strput.htm
} 
To Putin, such "functioning and effective democracy" first and foremost means the supremacy of the rule of the (federal) law on the whole territory. He stresses the importance of political and economic consolidation as a strategy to secure it. In this regard, the emerging power structure may be characterized as a shift from a weak democratic (corresponding to loose federation) to a weak authoritarian (corresponding to centralized federation) regime in its formation stages. ${ }^{175}$ Enlargement of regions may not be the panacea to Russia's state-building challenges, but it is definitely one of the building blocks of the new Russia as current leadership envisions it.

In light of the ongoing and completed regional enlargements, Russia is only statistically becoming a more horizontally symmetrical federation. At the same time, its vertical asymmetry increases. At this stage of the "collection of the Russian Lands," the changes in the federal system are unlikely to backfire against its architects. However, regardless of the abolishment of autonomous okrugs from the system of Russian federalism, the true challenges to the integrity of the Russian Federation are postponed to a later date, while they have required an urgent solution since early 1990s. The nature of these challenges lies in the sphere of state security.

\footnotetext{
175 "In comparison with weak democracies, strong authoritarian regimes have better chances to secure the rule of law," in Castaneira and Popov, Framework Paper on the Political Economy of Growth in Russia and Central America.
} 


\section{SECURITY DILEMMA: REUNIFICATION OR DISINTEGRATION}

The security dilemma has always been vital for Russia. One of the earliest preserved Russian documents is the twelfth-century narrative "The Lay of the Host of Igor" describing an unsuccessful military campaign of Prince Igor' against the tribes of Polovets. ${ }^{176}$ Russian tsars inferred a lesson from this and other historic encounters that had resulted in Russia's conquest. Russian territories needed a unified state. Moreover, to secure its domain such state had to be militarily sound. Before the establishment of a federal state in the US, the only known form of government to maintain a large military contingent was a centralized (unitary) state. The bringing together of the Russian lands, the expansion of the territory through exploration and conquest, and the establishment of a strong centralized state was undertaken by both the monarchial dynasties and the communist elites throughout the last millennia.

At present, Russia once again stands up to the external threats in form of the expansion of radicalized Islam from the South, Chinese growing power in the East, and NATO expansion in the West. However, Russia is least vulnerable to foreign interference along its long and porous borders. It is much more vulnerable to centrifugal tendencies in the CIS and at home. The ongoing war in Chechnya and a chain of terrorist attacks in Moscow, Mahachkala, Vladikavkaz, Mineral'nye Vody, that culminated in September 2004 Beslan tragedy have intensified the debate of Russia's security. As a consequence, they raised questions about Russia's territorial integrity. In his late 2004 press conference President Putin denounced Russia's move away from the federal state to the Soviet-type

\footnotetext{
176 "Slovo o Polky Igoreve, Syne Svyatoslava, Vnyke Olega," $12^{\text {th- }}$ century narrative. Found in multiple versions online at http://www.pereplet.ru/XPOHOC/slovo
} 
unitary state, arguing that such transition would hinder economic development. At the same time, to support the reform of the gubernatorial electoral process, he noted that Russia "has still not emerged... from the danger zone" of disintegration. ${ }^{177}$ Viewing political instability, terrorism, and secessionism as major internal threats of modern Russia, he contends the president should have greater influence over regional politics. In light of the terrorist threat, he perceives the construction of a single (unified) vertical of executive power in Russia as means to counter it. Regional enlargement makes such strengthening of the executive branch an easier and a more structured process. Enlargement of regions, if successfully implemented on an all-Russia scale, truly completes the "construction of the vertical of power, which pierces Russia from top to bottom, providing for the unity of the state." 178

Russia has a number of "Muslim" republics, and as much as ten percent of its population is Muslim. Separatist tendencies prevailed in Muslim Republics of Tatarstan and Chechnya even before the breakup of the USSR. As a result of demands for autonomy and independence, the Checheno-Ingushskaya ASSR was split into Chechnya and Ingushetia. Tatarstan, having unsuccessfully bid for an upgrade from ASSR to Republican status within the Soviet Union in late 1980s, prospered in bargaining unrivaled concessions from the federal government during the parade of sovereignties. Thus, one of the greatest internal challenges to the territorial integrity of Russia lies in the accommodation of its Muslim Republics in a federated state.

\footnotetext{
${ }^{177}$ Press Conference by President Vladimir Putin, December 23, 2004, at p. 12-13. Online at www.kremlin.ru/eng/text/speeches/2004/12/23/1806 tvpe82915 81700.shtml

178 "Kakyu Strany Vyrastil Putin? Vosem' Prostyh Voprosov v Svyazi s Ego Vystypleniem 13 Sentiabrya" (What Kind of State Has Putin Grown? Eight Questions in Relation to His September 13 Address), Komsomol'skaya Pravda, September 14, 2004.
} 
Shireen Hunter, evaluating the Islamic factor in Russia's policy and the war in Chechnya, notes that "it is difficult to measure the extent to which these challenges strengthened centralization tendencies in Russia," and that (they) "intensified fears of Russia's possible fragmentation and provided strong popular support for Putin's recentralization drive." ${ }^{\prime 19}$ Further, she wonders whether ethnic federalism in Russia is obsolete, and contends that the "resistance to the fading of ethnic-based federalism remained largely isolated within a few republics." 180 Indeed, the ongoing war and the series of terrorist acts have granted Putin's government carte blanche to start the process of refurbishing Russian federalism. In addition to creation of federal districts and introduction of the system of appointment of governors, Putin's team has masterfully manipulated the disadvantageous position of autonomous okrugs. In an article on the changing electoral process in Russia, Nikolay Petrov of the Carnegie Center in Moscow suggests that reform (appointment of governors) starts off with the regions that are easier to manage. "The Kremlin has a chance to prepare with utmost care for the tougher cases that lie ahead." "181 I observe an identical pattern in the reform of Russian federalism. Enlargement first affects the ethno-territorial constituencies where the state is likely to meet least resistance, and successfully undertake the reform.

Despite the failures to reach compromise in Tyumen' and Irkutsk, the mergers in Perm' and Krasnoyarsk in 2003 and 2005 have proven the viability of the enlargement

\footnotetext{
${ }^{179}$ Shireen T. Hunter, with Jeffrey L. Thomas and, Alexander Melikishvili, foreword by Collins, James F., Islam in Russia: The Politics of Identity and Security, Armonk, NY, M.E. Sharpe, 2004, at p. 205-206.

${ }^{180}$ Shireen T. Hunter, et. al., p. 233.

${ }^{181}$ Nikolay Petrov, "The Shape of Strings to Come," The Moscow Times, March 4, 2005, p.8. Online at the Carnegie Endowment for International Peace website www.ceip.org
} 
agenda. And despite the achieved changes in state structure, it should be kept in mind that it has only been fifteen years since the breakup of the USSR: Russian political culture and system of governance is still susceptible to the legacy of a strong authoritarian state. If the long-term goal of the government is to create a more centralized, and at the same time a more symmetrical and stable state, the reform is likely to result in creation of a unitary state in Russia. This scenario is even more likely if the enlargement process continues at its current pace. Pauline Jones Luong observes that "the faster the pace of state-building, the more powerful the legacies of the previous regime and state structures." 182 In fact, it is possible that Russia will undergo a process of "recombinance," which would result in a symbiosis of old and new state structures. The regional enlargement and the Kremlinization may enhance the chances of the old institutions to dominate the new ones.

The first step of Putin's reforms created Federal Districts. The second step is likely to abolish autonomous okrugs and facilitate a substitution of ethno-territorial with administrative-territorial federative division. I contend that the third logical step would encompass renegotiation of power-sharing agreements with ethnic constituencies with the status of (ethnic) republics, like Tatarstan and Bashkortostan. A comprehensive agreement on the status of Chechnya in the Russian Federation may be expected to follow. ${ }^{183}$

\footnotetext{
${ }^{182}$ Pauline Jones Luong, December 2002, p. 542.

${ }_{183}$ President Putin has been claiming that the federal government is ready to settle the status of Chechnya in the Russian Federation. In a press conference on talks with Silvio Berlusconi on November 5, 2003 Putin claimed his government had been "ready to sign an agreement with Cehchnya on limiting powers, which gives them wide autonomous rights" (online at www.kremlin.ru/eng/speeches/2003/11/05/2240 55109.shtml). However, few steps toward this goal have been taken, and the negotiation process has been backsliding. Federal troops are still on the
} 


\section{IMPLICATIONS FOR FUTURE STUDIES}

The implications of this study are important to in-depth understanding of the dynamics of the current changes in the federative structure of Russia. The state's federative division and its formation remain essential elements of the study of the direction that Russia will undertake in its development in the rapidly changing twentyfirst century political environment. This research is primarily a contribution to drawing and analyzing vectors and establishing patterns of Russia's future.

Will Russia manage to maintain and develop an effective and balanced federalism and evolve by the principles of democracy, follow the model of development of authoritarian South East Asian and Latin American states, or will it produce a new hybrid or unique system of federalism? To what extent will the Russian internal division be a factor in such evolution? The enlargement of the Russian regions that, as a consequence, may create fewer subjects of the Federation will remain the research focus for scholars of federalism and Russia. The study of this process and its results may help to answer the above-stated broad question and other narrower questions more accurately and profoundly.

Whether Russia will succeed in the implementation of the model envisioned by Putin's administration for its formation, consolidation, and development in its new division structure would impact its economy and the future domestic and international

ground in Chechnya. Assassination of the Chechen President Ahmad Kadyrov in May 2004 and the recent killing of the former President of Chechnya (Ichkeria) Aslan Maskhadov have further postponed reaching a peaceful compromise. 
policies. The success of failure to constitutionally re-balance the Russian Federation by changing its administrative divisions is likely to have tremendous implications for its future. Moreover, if the mergers of regions were indeed a long-term trend, they would have a direct impact on Russia, and possibly determine the state's overall success or failure.

First, the mergers would establish Russia as a federative or a unitary state. The adoption of a unitary state model in Russia would likely impede its development and reverse the gains of the fifteen years of the post-Soviet change. In other words, the Russian Federation can return to the starting point of its formation and find itself structured like RSFSR. Moreover, by establishing fewer regions, such structure in an undemocratic political setting may actually develop beyond RSFSR, and into a smallscale USSR. However, if Russia were to form a state along the principles of federalism, the mergers or its constituencies and the subsequent development of interregional and federal-regional interaction would determine the degree of its federative symmetry or asymmetry.

Second, since the state structure is in many respects the framework of its constitution and vice versa, the size of the constituencies would have implications for governing Russia. This would be manifested in citizens' rights, including the rights of numerous ethnic and religious minorities, and their role in the country's politics. Therefore, it would either impede or enhance the establishment of a pluralist society and consolidated democracy in Russia. 
Third, the result of the process of the interregional mergers would largely determine the budgetary and fiscal policy of the state and the nature of Russian capitalism, which in turn would impact Russia's socioeconomic and demographic development.

The success or failure of the policy of the enlargement of Russian regions can help assess the foresightedness of Putin's presidency and administration.

Also, it is unclear to what extent is the Russian Federation likely to reflect its multiethnic character in terms of federal division as well as the representation of the smaller ethnicities at the regional and federal levels. With autonomous okrugs absorbed by greater regions, and ethnic republics balanced among each other and within federal districts and the state, the need to maintain a federated structure of the state may diminish. Thus, should Russia manage to find a solution to the challenges of the ethnic republics of the Northern Caucasus, federal structure may become obsolete for the purposes of maintenance of vertical federal symmetry. If so, Russia may indeed revert to nominal federalism of the RSFSR. Therefore, it is important to monitor the process of enlargement and the reaction of the Northern indigenous ethnicities to the enlargement initiatives.

As of August 2005, the vector of Russia's path to statehood remains a dilemma and a disputed subject among politicians and scholars. Certainly, among the great number 
of debated issues around Russia's development and future, the enlargement of regions would occupy a prominent place. More research on Russian regional merger, including the assessment of the enlargements in retrospect, would contribute to studies in state building, democratization, and federalism.

Finally, the case studies in Russian regional enlargement and their results will contribute to fundamental research on budgetary federalism, ethnic federalism, symmetrical federalism, and on state building and evolution of states. 


\section{REFERENCES}

James Alexander, Federal Reforms in Russia: Putin's Challenge to the Republics, Demokratizatsiya, Vol. 12, Issue 2, Spring 2004, p. 233-263

Fredo Arias-King, The Centrality of the Elites, Demokratizatsiya, Vol. 11, Issue 1, Winter 2003, p. 150-160

Aleksei Avtonomov, Principles of Federalism in Russia and USA: Comparative Aspect, Kazan Federalist, Number 4(8), Kazan Institute of Federalism, Autumn, 2003

Mikhail Beliaev, Putin's Russia: Is It a Doable Project? Demokratizatsiya, Vol. 12, Issue 1, Winter 2004, p. 13-39

Klaus von Beyme, "Federalism in Russia," in Federalism and Political Performance, Ute Wachendorfer-Schmidt (Ed.), London, New York, Routledge, 2000, p. 23-39.

Ralph S. Clem, Peter R. Craumer, "Regional patterns of political preference in Russia: The December 1999 Duma elections," Post-Soviet Geography \& Economics, JanuaryFebruary 2000, Vol. 41, Issue 1, p. 1-30

L Evstigneeva, R Evstigneev, Subfederal Aspects of Globalization, Problems of Economic Transition, October 2003, Vol. 46, Issue 6, p. 6

J. Paul Goode, The Push for Regional Enlargement in Putin's Russia, Post-Soviet Affairs, Vol. 20, No. 3, 2004, p. 219-257

Dmitry Gorenburg, Regional Separatism in Russia: Ethnic Mobilization or Power Grab? Europe-Asia Studies, Vol. 51, No. 2, 1999, p. 245-274

Anna Grzymala-Busse and Pauline Jones Luong, Reconceptualizing the State: Lessons from Post-Communism, Politics and Society, Col. 30, No. 4, December 2002, p. 529-554

Nikolas K. Gvosdev, The Sources of Russian Conduct, National Interest, Issue 75, March 1, 2004

Henry E. Hale, Explaining Machine Politics in Russia's Regions: Economy, Ethnicity, and Legacy, Post-Soviet Affairs, July-September 2003, Vol. 19 Issue 3, p. 228-264 
Fiona Hill, Governing Russia: Putin's Federal Dilemmas, New Europe Review, January 2005

Fiona Hill and Clifford Gaddy, The Siberian Curse: How Communist Planners Left Russia Out in the Cold, Brookings Institution Press, Washington DC, 2003

Shireen T. Hunter, with Jeffrey L. Thomas, and Alexander Melikishvili, foreword by James F. Collins, Islam in Russia: The Politics of Identity and Security, Armonk, NY, M.E. Sharpe, 2004

Arend Lijphart, Democracy in Pluralist Societies, Yale University Press, 1977

Juan J. Linz and Alfred Stepan, Problems of Democratic Transition and Consolidation, Johns Hopkins University Press, Baltimore, 1996

Pauline Jones Luong and Erika Weinthal, Prelude to the Resource Curse. Explaining Oil and Gas Development Strategies in the Soviet Successor States and Beyond, Comparative Political Studies, Vol. 34, No. 4, May 2001, p. 367-399

Vladimir Lysenko, The Development of the Federal Okrugs and the Future of Federalism in Russia, Kazan Federalist, Number 4(8), Kazan Institute of Federalism, Autumn, 2003

Christopher Marsh and James W. Warhola, Ethnicity, Ethnoregionalism, and the Political Geography of Putin's Electoral Support, Post-Soviet Geography \& Economics, 2001, Vol. 42, Issue 3, p. 220-234

Alastair McAuley, The Determinants of Russian Federal-Regional Fiscal Relations: Equity or Political Influence? Europe-Asia Studies, Vol. 49, No. 3, 1997, p. 431-444

Emil Pain, Recent Administrative Reforms and Their Effect on Ethnopolitical Processes in Russia, Kazan Federalist, Number 4(8), Kazan Institute of Federalism, Autumn, 2003

E.V. Pershin, M.V. Gligich-Zolotaryova, and Yu. V. Malinkina, Problemy Zakonodatel'nogo Obespecheniya Ykrypneniya Syb'ektov Rossiiskoi Federatsii (na Primere Ob'edinenniya Permskoi Oblasti i Komi-Permyatskogo Avtonomnogo Okruga) [Problems of Legislative Base for the Enlargement of the Subjects of the Russian Federation (on theExample of the Unification of Perm' Oblast' and Komi-Permyatskii Autonomous Okrug)], Analyticheskii Vestnik Federal'nogo Sobraniya Rossiiskoi Federatsii, No. 6 (226), Moscow, 2004

E.V. Pershin, M.V. Gligich-Zolotaryova, A. N. Dementiev, and Yu. V. Malinkina, Aktual'nye Problemy Territorial'noi Organizatsii Pyblichnoi Vlasti: Opyt Rossii I Zarybezhnykh Stran, Chast' 1, Regional'nyi Yroven' (Current Problems of Territorial Organization of Power: Experience of Russia and Foreign Countries, Part 1, Regional Level), Analyticheskii Vestnik Federal'nogo Sobraniya Rossiiskoi Federatsii, No. 18 (211), Moscow, 2003 
Nikolai Petrov, "Federalism," in Michael McFaul, Nikolai Petrov, and Andrei Ryabov, with Mikhail Krasnov, et. al., Between Dictatorship and Democracy: Russian PostCommunist Political Reform, Washington, D.C., Carnegie Endowment for International Peace, 2004, Chapter 9, p. 213-238.

Richard Pipes, Russia Under the Old Regime, Charles Scribner's Sons, 1974

Richard Pipes, The Formation of the Soviet Union: Communism and Nationalism, 19171923, Rev. Ed., Cambridge, MA, Harvard University Press, 1997

Liudmila Pronina, The Reform of Federal Relations and Local Self-Government: Goals and Mechanisms of Realization in Budgetary and Tax Legislation, Kazan Federalist, Number 4(8), Kazan Institute of Federalism, Autumn, 2003

Scott Radnitz, The Tyranny of Small Differences: The Relationship between Ethnic Diversity and Democracy in the Former Socialist Block, Demokratizatsiya, Vol. 12, Issue 4, Fall 2004, p. 575-606

Peter Reddaway and Robert W. Orttung (Eds.) The Dynamics of Russian Politics: Putin's Reform of Federal-Regional Relations, Lanham: Rowman \& Littlefield, 2004

Blair A. Ruble, Jodi Koehn, and Nancy E. Popson (Eds.), Fragmented Space in the Russian Federation, Washington, D.C.: Woodrow Wilson Center Press; Baltimore: John Hopkins University Press, 2001

Andreas Schedler, What is Democratic Consolidation? Journal of Democratic Consolidation, April 1998

Marat Salikov, "Russian Federation," in A Global Dialogue on Federalism, Volume I: Constitutional Origins, Structure, and Change in Federal Countries, John Kincaid and G. Alan Tarr (Eds.), John Kincaid (Senior Ed.), Montreal, McGill-Queen's University Press, 2005, p. 280-310.

Robert Sharlet, Constitutional Law and Politics in Russia: Surviving the First Decade, Demokratizatsiya, Vol. 11, Issue 1, Winter 2003, p. 122-128

Robert Sharlet, Resisting Putin's Federal Reforms on the Legal Front, Demokratizatsiya, Vol. 11, Issue 3, Summer 2003, p. 335-342

Graham Smith, Russia, Ethnoregionalism and the Politics of Federation, Ethnic \& Racial Studies, April 1996, Vol. 19, Issue 2, p. 391-411

Steven L. Solnick, The Political Economy of Russian Federalism, Problems of PostCommunism, Vol. 43, Issue 6, November-December 1996, p. 13-26 
John Squier, Civil Society and the Challenge of Russian Gosudarstvennost', Demokratizatsiya, Vol. 10, Issue 2, Spring 2002, p. 166-182

Mikhail Stoliarov, Federalism and the Dictatorship of Power in Russia, Routledge, London, New York, 2003

Charles D. Tarlton, Symmetry and Asymmetry as Elements of Federalism: A Theoretical Speculation, The Journal of Politics, Vol. 27, Issue 4, 1965, p. 861-874

Judith Thornton and Charles E. Ziegler (Eds.), Russia's Far East: a Region at Risk, Seattle, National Bureau of Asian Research in Association with University of Washington Press, 2002

Valery Tishkov, Ethnicity, Nationalism, and Conflict in and After the Soviet Union: The Mind Aflame, London, Sage, 1997

Ronald Watts, Comparing Federal Systems in the 1990s, Kingston, Ontario, 1996

Ronald Watts, Comparing Federal Systems, 2nd Ed., McGill-Queen's University Press, Montreal and Kingston, Ontario, 1999 (Chapter 6 "Symmetry and Asymmetry in Federations, p. 63-68)

\section{LEGISLATION}

Constitution of the Union of Soviet Socialist Republics, October 7, 1977, Available online at http://www.thisnation.com/library/ussr.html

Constitution of the Russian Federation, December 12, 1993, Available online at http://kremlin.ru/eng/articles/ConstMain.shtml

Law on Mineral Resources (Draft), the Ministry of Natural Resources of the Russian Federation, March 5, 2005, The referenced or later version available in Russian online at www.mnr.gov.ru

Federal Constitutional Law of the Russian Federation N1-FKZ "On the Formation of a New Subject of the Russian Federation as a Result of the Unification of Perm' Oblast' and Komi-Permyatskii Autonomous Okrug" (Ob Obrazovanii v Sostave Rossiiskoi Federatsii Novogo Sub'ekta Rossiiskoi Federatsii v Rezy'tate Ob'edineniya Permskoi Oblasti I Komi-Permyatskogo Avtonomnogo Okruga), March 25, 2004, in Rossiiskaya Gazeta, March 26, 2004 and online at www.krai.perm.ru

Decree of the President of the Russian Federation, On The Order of Consideration of Candidacies for the Highest Authority (Head of the Executive Branch) of the Subject of the Russian Federation, No. 1603, in Rossiiskaya Gazeta No. 289 (3666), December 29, 2004, p. 2. 
Decree of the President of the Russian Federation "On the State Council of the Russian Federation, September 1, 2000.

Decree of the President of the Russian Federation "On Plenipotentiary Representatives of the President of the Russian Federation to the Federal Districts, May 13, 2000.

Budget of the Russian Federation for the fiscal year 2004. Available online at www.bugdetrf.ru and www.minfin.ru 


\section{APPENDIX 1 NOTE ON TRANSLITERATION AND TERMINOLOGY}

Considering the small number of case studies that I undertake in this paper, I have chosen to use English transliterations for a number of Russian geographical terms and titles of the Russian territorial division. The Russian terms that I use are as follows:

- In translation of proper names, I use the transliteration suggested by Democratizatsiya magazine. Wherever possible, I provide English equivalents of Russian terms in parentheses or in footnotes. For example, I only partially translate "Perm' Region," and use the term "Perm' Oblast", and not "Permskaya Oblast" to avoid confusion with and distinguish from "Perm' Krai" (Permskii Krai). At times, I refer to oblast by name of its capital city. For example, "merger of Perm' and KPAO" refers to merger of Perm' Oblast' and Komi-Permyatskii Autonomous Okrug. Otherwise, I clearly identify that I reference Perm', Tyumen', and other locations as cities.

- I use abbreviations for convenience. For example, Komi-Permyatskii Autonomous Okrug (KPAO).

- I use acronyms and transliterate them from Russian. For example, The Ministry of Economic Development and Trade of the Russian Federation (Ministerstvo Ekonomicheskogo Razvitiya i Torgovli (MERT).

- I specifically describe the term Kremlinization in the Introduction.

- The terms region, state, constituency, subject (of the federation) are used as synonyms, which refer to units of the federative constitutional division of Russia, unless noted otherwise.

- Terms nation, nationality, ethnos, ethnicity are used as synonyms, which refer to ethnic groups historically settling the territory of Russia, unless noted otherwise.

* - English equivalents of Russian terms are used where possible in Orttung and Reddaway (Eds.), The Dynamics of Russian Politics: Putin's Reform of Federal-Regional Relations, Rowman \& Littlefield, 2004. 


\section{APPENDIX 2 \\ ABBREVIATIONS AND ACRONYMS}

AO - Autonomous Okrug (avtonomnyi okrug)

FAS - Federal Antimonopoly Service (Federal'naya Antimonopol'naya Sluzhba)

FD - Federal District (Federal'nyi Okrug)

GosKomStat - State Statistical Committee (Gosudarstvennyi Komitet po Statistike)

Gosplan - State Economic Planning

GRP - Gross Regional Product

KhMAO - Khanty-Mansiiskii Autonomous Okrug

KPAO - Komi-Permyatskii Autonomous Okrug

MERT - Ministry of Economic Development and Trade (Ministerstvo Ekonomicheskogo Razvitia i Torgovli $R F$ )

MinFin - Ministry of Finance (Ministerstvo Finansov RF)

MinNats - Ministry of Nationalities (Ministerstvo po Delam Natsional'nostei RF)

NDPI - Tax on Extraction of Mineral Resource (nalog na dobychu poleznykh iskopaemykh)

Polpred - Plenipotentiary Representative of the President of Russia in a Federal District (Polnomochnyi Predstavitel' Prezidenta $v$ Federal'nom Okruge)

RF - The Russian Federation

RSFSR - Russian Soviet Federated Socialist Republic

U-OBAO - Ust'-Ordynskii Buriatskii Autonomous Okrug

VPK - Military-Industrial Complex (Voyenno-Promyshlennyi Kompleks)

VTSIK - All-Russia Central Electoral Commission (Vserossiiskaya Tsentral'naya Izbiratel'naya Komissiya)

VTSIOM - All-Russia Center for Study of Public Opinion (Vserossiiskii Tsentr Issledovniya Obshestvennogo Mneniya)

YaNAO - Yamalo-Nenetskii Autonomous Okrug 


\section{APPENDIX 3 \\ FORMS OF RUSSIAN REGIONS}

Republic, krai, oblast', autonomous oblast', federal city, and autonomous okrug (AO) are six forms of the 89 Russian Federation constituencies. Despite the difference in forms, their nominal status is uniform (Article 65 of the Russian Constitution).

Oblast' - most common Russian form of region; its borders are usually administrativeterritorial; population is predominantly ethnic Russian. Russian Federation contains 49 oblasts (48 upon the formation of Permskii Krai).

Krai - literally means "edge." Formerly frontier regions of Russia; in modern Russia krais are usually a large oblasts. In the Soviet Union, krais usually incorporated autonomous okrugs. Thus, their borders combined administrative-territorial and ethnoterritorial charateristics. Russian Federation contains 6 Krais $(7$ upon the formation of Permskii Krai).

Republic - region containing a major (usually over one million) titular ethnicity, to which the region (autonomy) had been assigned in the RSFSR - now the Russian Federation. Republican borders are ethno-territorial, although ethnic Russians constitute a majority in most ethnic republics, and the borders no longer reflect a clear ethnic divide. Republics have a right to adopt their own constitutions to complement and not contradict the federal Constitution. Other forms of regions adopt charters. Russian Federation contains 21 Republics.

Autonomous Okrug - region containing a smaller (less than one million) titular ethnicity. Okrugs are homes to small (indigenous) ethnicities of the Russia's North. Their borders are ethno-territorial, although, like in the republics, their populations are not homogeneous and may include sizeable ethnic Russian or other ethnic populations. Russian Federation contains 10 autonomous okrugs (7 upon enlargement of KomiPermyatskii, Taimyrskii (Dolgano-Nenetskii), and Evenkiiskii Autonomous Okrugs).

Autonomous Oblast' - same as autonomous okrug. Russian Federation contains only one region of this status - the Jewish Autonomous Okrug.

Federal City - cities of federal importance (significance). Russian Federation contains only two such regions - the City of Moscow and the City of Saint Petersburg. The borders of these regions are administrative-territorial.

Source: Constitution of the Russian Federation. Full text available online in English at

http:/www.kremlin.ru/eng/articles/ConstEngl.shtml 


\section{APPENDIX 4 \\ Article 66 of the Russian Constitution, Adopted by National Referendum on December 12, 1993}

1. The status of a Republic shall be determined by the Constitution of the Russian Federation and the Constitution of the Republic.

2. The status of a territory, region, city of federal importance, autonomous region and autonomous area shall be determined by the Constitution of the Russian Federation and the Charter of the territory, region, city of federal importance, autonomous region or autonomous area, adopted by the legislative (representative) body of the corresponding subject of the Russian Federation.

3. Upon the proposal of the legislative and executive bodies of the autonomous region or autonomous area a federal law on autonomous region or autonomous area may be adopted.

4. The relations between the autonomous area within a territory or region may be regulated by the federal law or a treaty between the bodies of state authority of the autonomous area and, accordingly, the bodies of state authority of the territory or region.

5. The status of a subject of the Russian Federation may be changed upon mutual agreement of the Russian Federation and the subject of the Russian Federation and according to the federal constitutional law.

Source: http:/kremlin.ru/eng/articles/ConstMain.shtml 
Scheme 1

Federal Symmetry *

\section{A 1. Vertical symmetry in a federation}

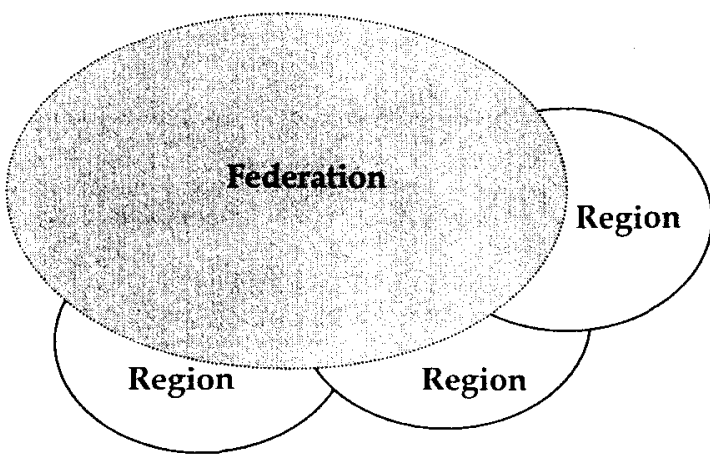

Vertical Asymmetry: power is skewed towards federation in a more centralized state. Constituencies have little power in their own affairs and at the federal level.

A 2.

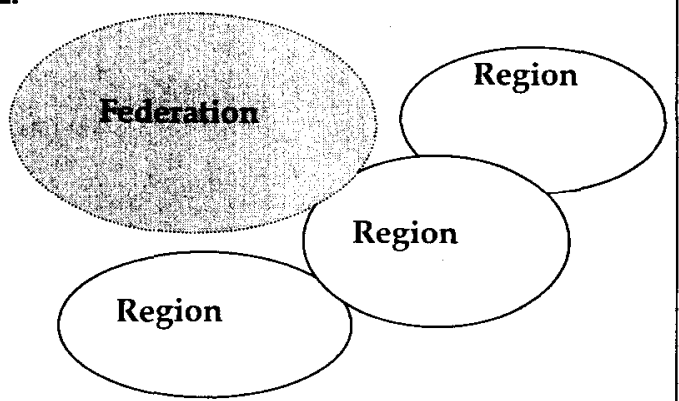

Vertical Asymmetry: power is skewed towards regions in a loose federation with vast regional autonomy. Regions are semi-independent of the federation. This form may serve as a transitory form to the breakup of a federation into independent states or formation of a confederation. Russia is currently moving from being a loose federation (A 2) to a more centralized federation (A 1).

* - Scheme drawn by the author

\section{B 1. Horizontal symmetry in a federation}

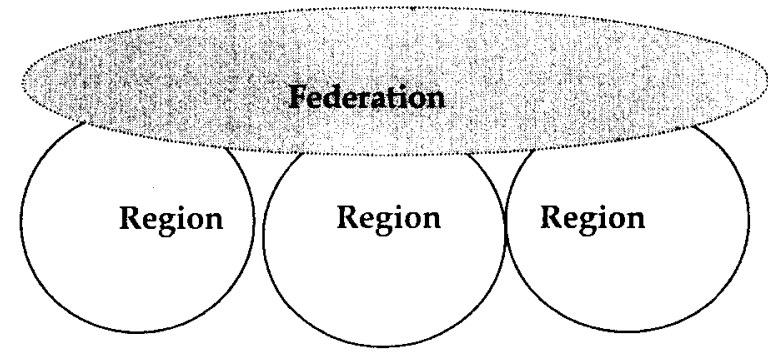

Horizontal Symmetry: regions are approximately equal in power to each other and in relation to federation. They are equally represented at the federal level. It is also desirable they are roughly equal in area, population, size of economy.

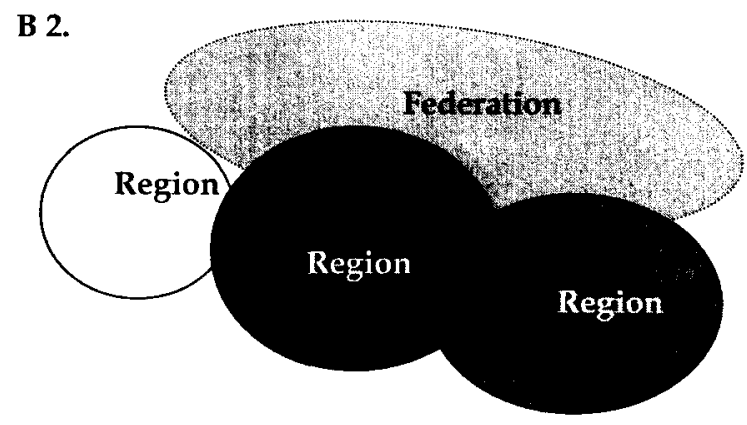

Horizontal Asymmetry: regions are unequal in power to each other (and in relation to federation). Some regions have more leverage at the federal level and over other regions. Others are marginalized. Russia during the "parade of sovereignties" is a clear example of this kind of asymmetry. 
Scheme 2: Federation as a Dynamic Organizational Structure of States

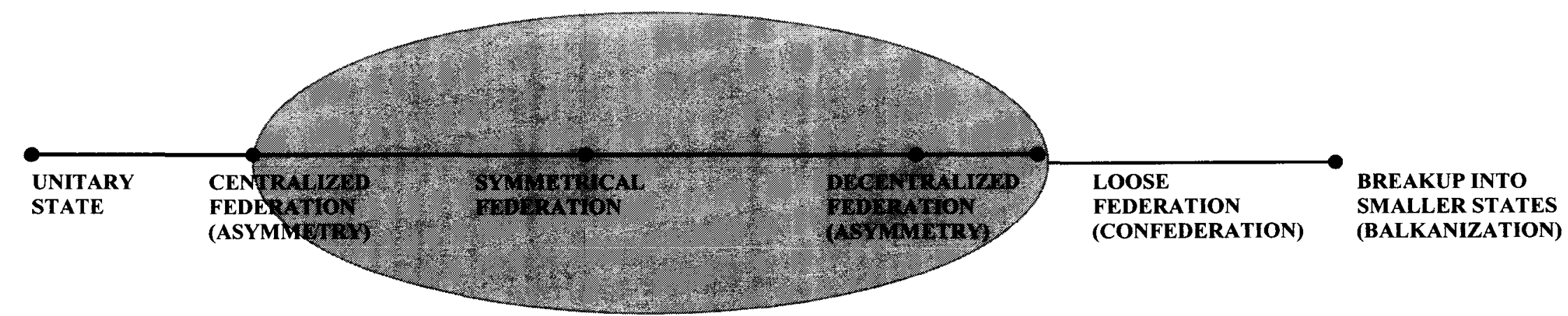


Scheme 3. Dynamics of Russian Federalism: 1990-2005

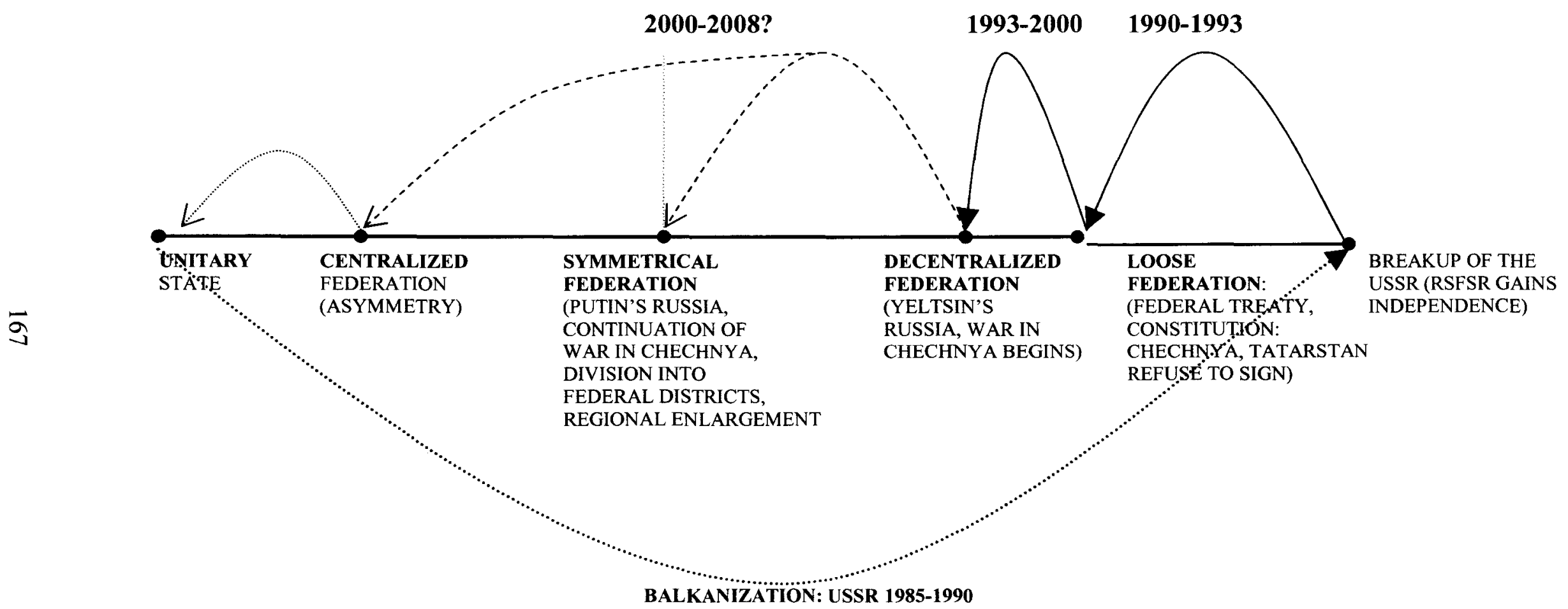




\section{Scheme 4}

Ratio of the Direct and Reverse Flows between Federal Budget and Siberian Federal District (Per 100 rubles of transfers to the Federal Budget), January-September 2004 *

Donor Regions of the Siberian Federal District

1. Krasnoyarskii Krai

2. Irkutsk Oblast'

3. Kemerovskaya Oblast'

4. Novosibirsk Oblast'

5. Omsk Oblast'

6. Tomsk Oblast'
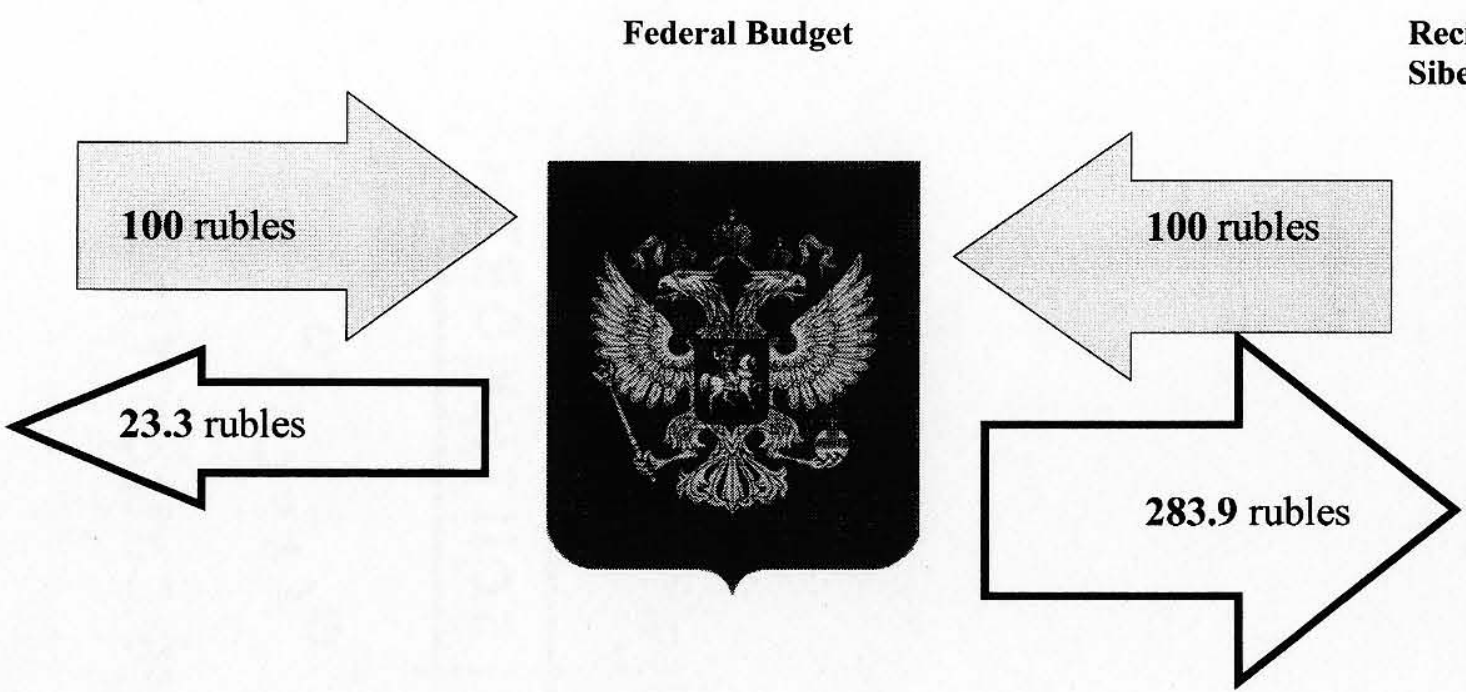

Recipient Regions of the Siberian Federal District

1. Republic of Altai

2. Republic of Buriatia

3. Republic of Tuva

4. Republic of Khakasia

5. Altaiskii Krai

6. Chita Oblast'

7. Aginskii Buriatskii $\mathrm{AO}$

8. Taimyrskii $\mathrm{AO}$

9. Ust'-Ordynskii

Buriatskii AO

10. Evenkiiskii AO

Source: (Sootnosheniya Pryamykh i Obratnykh Potokov mezhdy Federal 'nym budjetom I SFO), January-September 2004, in Boris Lavrovskii, "One more Year of Unstable Development," (Eshyo Odin God Neystoichivogo Razvitiya), Expert-Sibir' Magazine, No 15 (67) April 18, 2005

* - On average, a transfer of 100 rubles from the territory of Siberian Federal District to the federal budget relates to 57.6 rubles; same average for transfers from all federal districts is 22.5 rubles.

Note that all ethnically defined subjects of the Federation in the Siberian Federal District (republics and autonomous okrugs) are recipients. All oblasts, except Chita, are, on the opposite, donors.

Also note the path dependency of regions of the Siberian Federal Districts. All donor regions, unlike recipients, have direct access to the Trans-Siberian Railroad (BAM), and are also major airport hubs. 


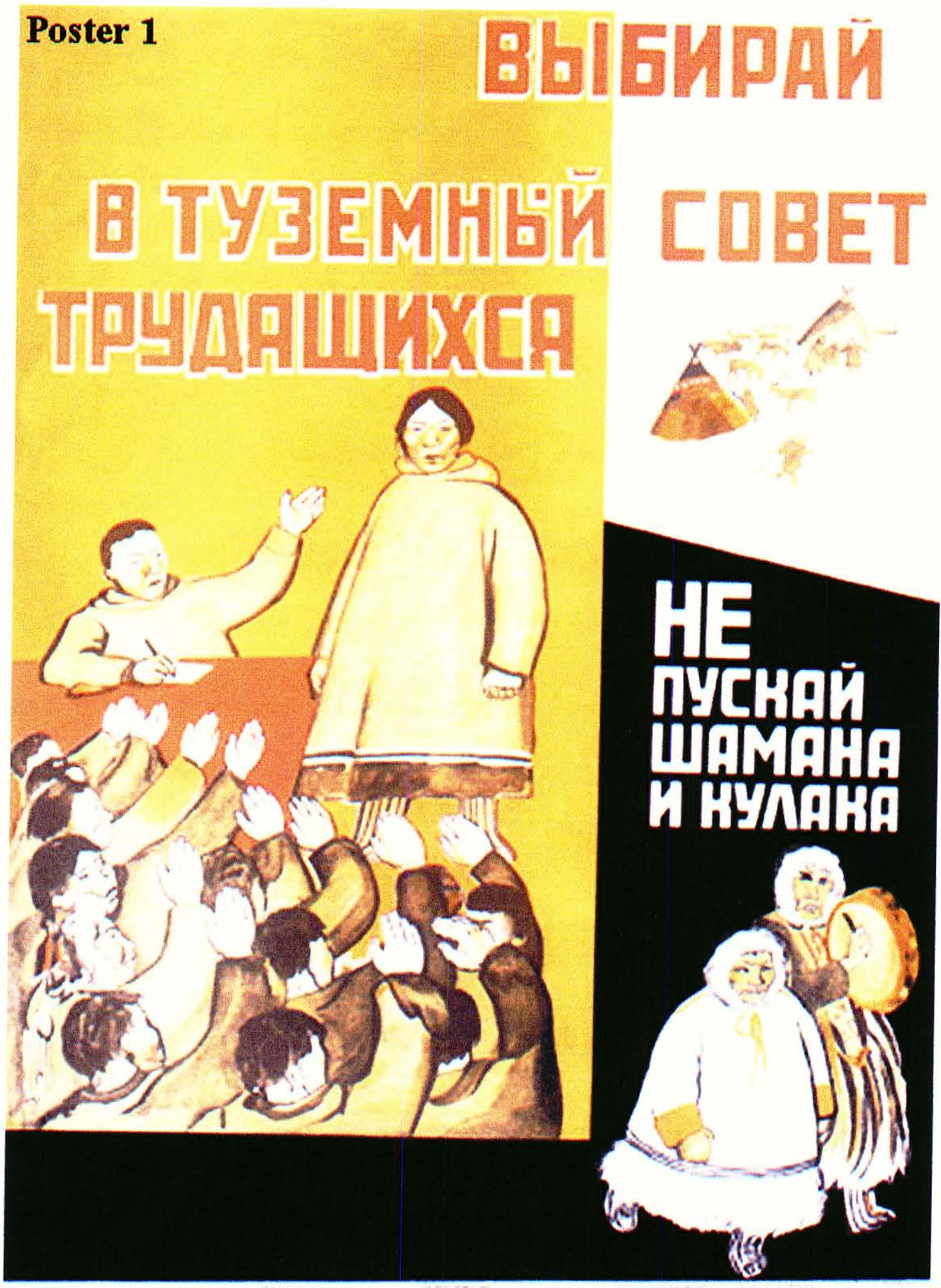

Georgii Khoroshevskii, "Vybirai v Tuzemnyi Soviet Tryduashihsa-Ne Pyskai Shamana i Kylaka" (Elect the Native Workers' Soviet: Don't Let Shaman and Kulak in), 1931

Source: http://orel.rsl.ru/meeting_on fr/plakat2/077.htm 


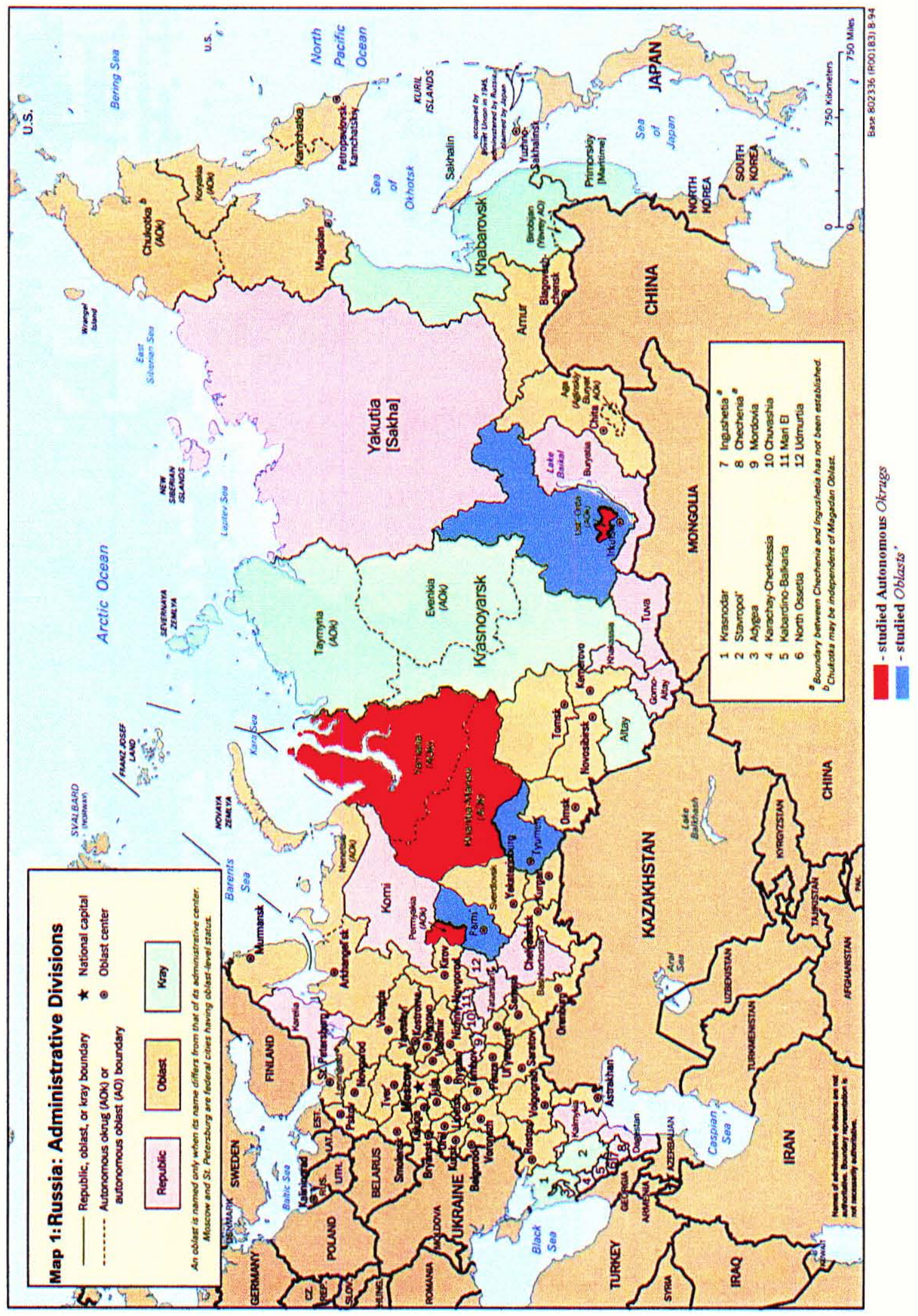

Source: Perry-Castaneda Maps, University of Texas Library, online at http://www.lib.utexas.edu/maps/commonwealth/russiaaddivisions.jpg (studied areas marked by the author) 


\section{Autonomous Areas in Russia}

MAP 2

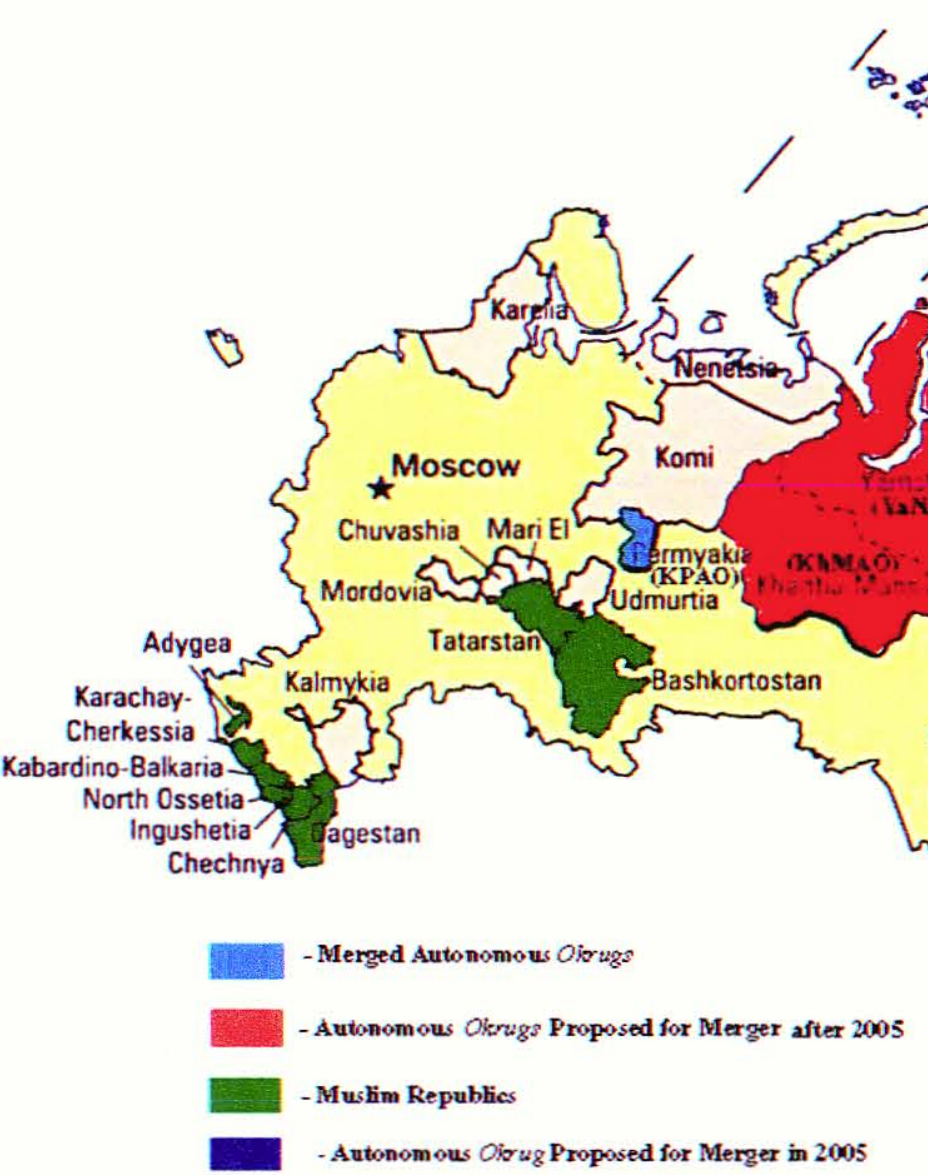




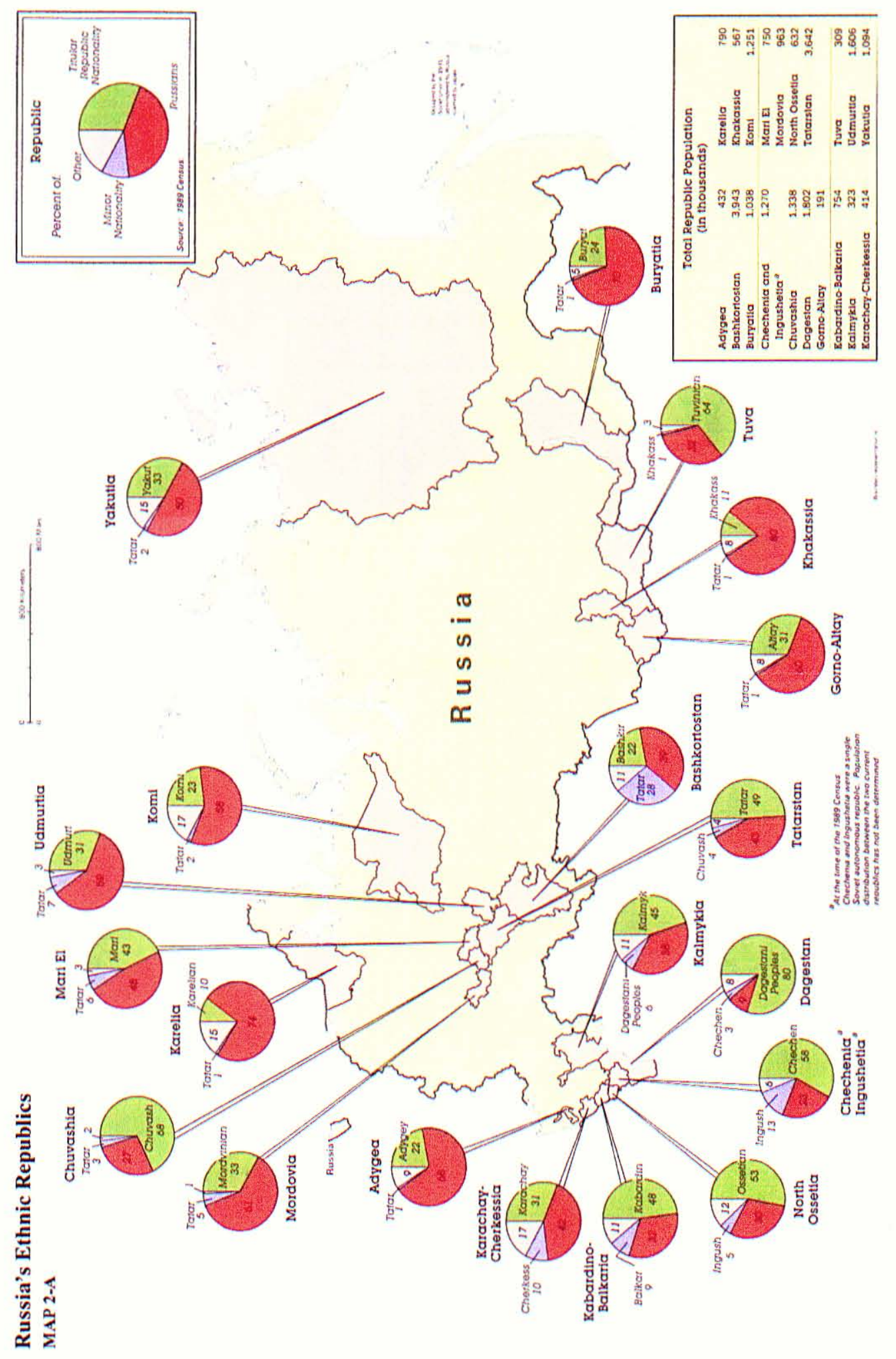

Source: Perry-Castaneda Maps, University of Texas Library, online at http://www.lib.utexas.edu/maps/commonwealth/russia ethnic94.jpg 


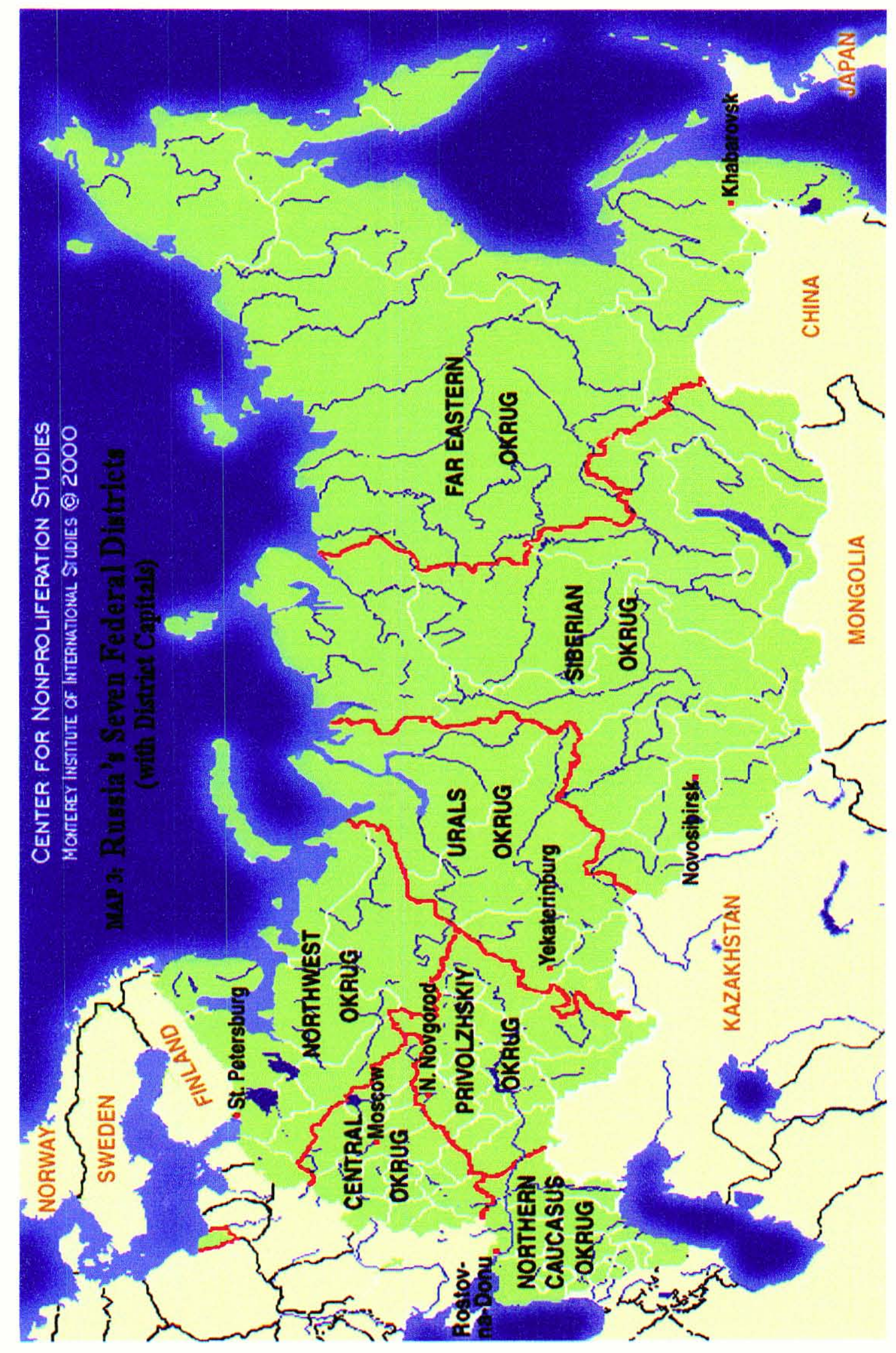

Source: Center for Nonproliferation Studies, Monterrey Institute of International Studies, 2000. 


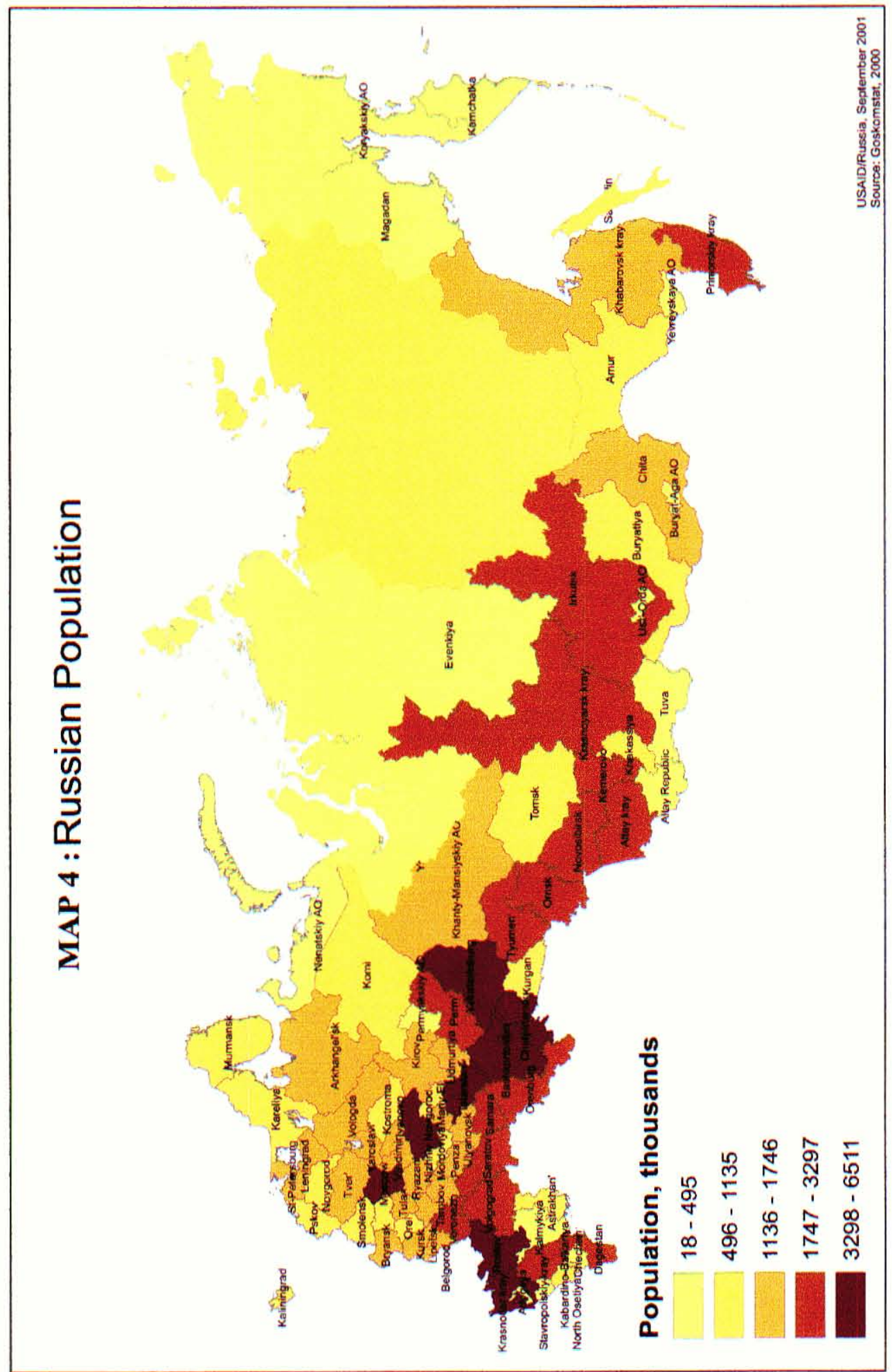

Source: USAID, September 2001, online at

http://www.lib.utexas.edu/maps/commonwealth/russia_population_usaid_2000.pdf 
Table 1. Dynamics of Russian Federal Division

\begin{tabular}{|c|c|c|c|}
\hline \multirow[t]{2}{*}{ Time Period } & \multicolumn{2}{|c|}{ Type of Border } & \multirow{2}{*}{$\begin{array}{c}\text { Total } \\
\text { Number of } \\
\text { Subjects }\end{array}$} \\
\hline & $\begin{array}{c}\text { Administrative- } \\
\text { Territorial }\end{array}$ & $\begin{array}{c}\text { Ethno- } \\
\text { Territorial }\end{array}$ & \\
\hline $\begin{array}{l}\text { RSFSR before } 1990 \\
\text { (one of } 15 \text { constituencies of the } \\
\text { USSR) }\end{array}$ & 57 & $16(+15) *$ & $88(73) * *$ \\
\hline $\begin{array}{l}\text { Russian Federation in 1990- } \\
2003 \text { (Breakup of the USSR, } \\
\text { Yeltsin's Presidency, } \\
\text { devolution) }\end{array}$ & 57 & 32 & 89 \\
\hline $\begin{array}{l}\text { Russian Federation in 2000- } \\
2005 \text { (Putin's Presidency, } \\
\text { recentralization) }\end{array}$ & 57 & 29 & $86 * * *$ \\
\hline
\end{tabular}

* - The total number of ethno-territorial constituencies equaled 31 , including 16 autonomous constituencies (ASSR), and 15 second-tier autonomous units, included in other first-tier constituencies (matryoshka).

** - 73 refers to firs-tier units, some of them containing the 15 second-tier autonomous units.

*** - Should regional enlargement continue throughout Putin's second term, I suggest the total number of ethno-territorial constituencies is likely to decrease to $20-25$, and the total number of constituencies to $75-80$. 
Table 2. General Political and Administrative Information on the Studied Regions

Region

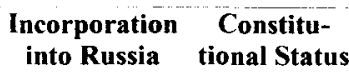

Perm’ Region

Oblast

1938

Komi-Permyatskii

$\mathrm{AO}$

Permskii Krai

After Merger

Tyumen' Region

Avonomi $P$

Krai

05

Oblast'

Agreement with the

Federation, Current

$$
\text { Status }
$$

NE part of East European Plain. Borders 5 Agreement Cancelled regions. Includes $1 \mathrm{AD}, 37$ regions, 25 cities, $200 \mathrm{l}$

55 towns. $1400 \mathrm{~km}$ NE of Moscow

Avtonomnyi Preduralie, Kama river upstream, $1400 \mathrm{~km}$ Agreement Cancelled, 2002 Volg

NE of Moscow

Merger Agreement

Volga

signed, February 17, 2003

Federal
District
(Federal'nyi
Okrug)

Military Economic Region

District (Ekonomicheski

(Voennyi

Okrug) (Voennyi

Raion)

Head of

Volga

(Privolzhskii)

Okrug)

Urals (Uralskii

Raion)

(Privolzhsk

Volga-Urals Urals

Urals

Volga-Urals Urals

W Siberian Plain. Borders Kazakhstan and 7 Agreement Cancelled, Ural (Ural'skii) Volga-Urals

Russian regions. Includes 2 ADs, 5 cities of November 29, 2001

Ural (Ural'skii) Volga-Urals ${ }^{-}$West- Siberian

(Zapadno-

Sibirskii)

ubordination $2100 \mathrm{~km}$ E of Moscow

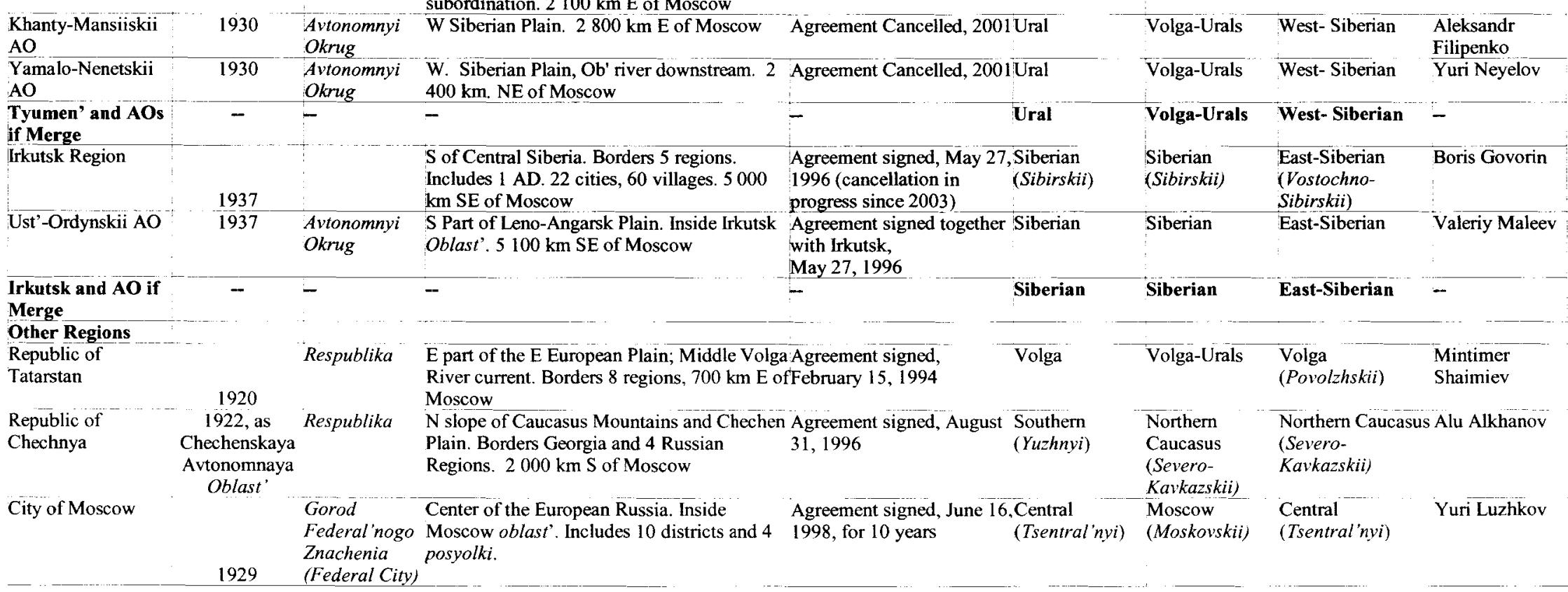


Table 3. Number of Ethnic Russians and Other Large Ethnic Groups in Studied Regions

\begin{tabular}{|c|c|c|c|c|c|c|c|}
\hline \multirow[b]{2}{*}{ Region } & \multirow{2}{*}{$\begin{array}{c}\text { Total } \\
\text { Population of } \\
\text { Region }\end{array}$} & \multirow{2}{*}{$\begin{array}{l}\text { Number of } \\
\text { Ethnic } \\
\text { Russians* }\end{array}$} & \multicolumn{3}{|r|}{ Proportion of Ethnicities } & \multirow[b]{2}{*}{$\begin{array}{l}\text { Fourth Largest } \\
\text { Ethnicity }\end{array}$} & \multirow[b]{2}{*}{$\begin{array}{c}\text { All Other } \\
\text { Ethnicities }\end{array}$} \\
\hline & & & Largest Ethnicity & $\begin{array}{l}\text { Second Largest } \\
\text { Ethnicity }\end{array}$ & $\begin{array}{l}\text { Third Largest } \\
\text { Ethnicity }\end{array}$ & & \\
\hline Perm' Oblast' & 2683345 & 2349713 & Russian & Tatar, 135497 & Bashkir, 40690 & Udmurt, 26073 & 131372 \\
\hline Komi-Permyatskii AO & 136076 & 51946 & $\begin{array}{l}\text { Komi-Permyak**, } \\
80327\end{array}$ & Russian & Tatar, 1100 & Ukrainian, 706 & 1952 \\
\hline $\begin{array}{r}\text { Perm' and AO after Merger } \\
\text { (Permskii Krai) } \Delta\end{array}$ & 2819421 & 2401659 & Russian & Tatar, 136597 & $\begin{array}{l}\text { Komi-Permyak, } \\
103505\end{array}$ & Bashkir, 40740 & 136920 \\
\hline Tyumen' Oblast' & 1325018 & 1091571 & Russian & Tatar, 106954 & Ukrainian, 22054 & German, 16320 & 88119 \\
\hline Khanty-Mansiiskii $\mathrm{AO}^{\wedge}$ & 1432817 & 946590 & Russian & Ukrainian, 123238 & Tatar, 107637 & Bashkir, 35807 & 219545 \\
\hline Yamalo-Nenetskii AO^^^ & 507006 & 298359 & Russian & Ukrainian, 66080 & Tatar, 27734 & Nenets**, 26435 & 88398 \\
\hline $\begin{array}{r}\text { Tyumen' and AOs after } \\
\text { Merger }\end{array}$ & 3264841 & 2336520 & Russian & Tatars, 242325 & Ukrainian, 211372 & Bashkir, 46575 & 428049 \\
\hline Irkutsk Oblast' & 2446378 & 2246847 & Russia & Ukrainian, 52331 & Tatar, 26966 & Byruat, 26916 & 93318 \\
\hline Ust'-Ordynskii AO & 135327 & 73646 & Russian & Byruat**, 53649 & Tatar, 4102 & Ukrainian, 1300 & 2630 \\
\hline Irkutsk and AOs after Merger & 2581705 & 2320493 & Russian & Byruat, 80565 & Ukrainian, 53631 & Tatar, 31068 & 95948 \\
\hline Other Regions & & & & & & & \\
\hline Republic of Tatarstan & 3779265 & 1492602 & Tatar** $^{\star *}, 2000116$ & Russian & Chuvash, 126532 & Udmurt, 24016 & 135999 \\
\hline Republic of Chechnya & 1103686 & 40645 & Chechen $^{* *}, 1031647$ & Russian & Kymyk, 8883 & Avartsy, 4133 & 18378 \\
\hline City of Moscow & 10382754 & 8808009 & Russian & Ukrainian, 253644 & Tatar, 166083 & Armenian, 124425 & 1030593 \\
\hline
\end{tabular}

Source: Census 2002, GosKomStat data, http//www.perepis2002.ru/ct/doc/ALL_00_01.doc Russia's total population is 145166731 (January 2005 GosKomStat estimates the Russian population at 143400000 ). For statistics on small indigenous groups of Russia's North, Siberia, and the Far East and their population distribution in Russian regions, see http:/www.raipon.org/russian_site/people/people_perepis_2002_rus.htm The term small indigenous groups includes Nenets, Khanty, and Mansi. It does not include Komi-Permyaks and Buriats, because their total number exceeds 50000 .

* - For overall proportion of ethnic Russians and other ethnicities in the Russian Federation see Map 2-A

** - Titular Ethnicity

$\Delta$ - In addition, Permskii Krai will be home to the following nationalities (over 10000 ): Udmurt - 26 272, Ukrainian - 25948 , Byelorussian - 10989 , and German - 10152

$\hat{\wedge}$ - In addition, Khanty-Mansiiskii Autonomous Okrug is home to the following nationalities (over 10000 people): Azerbaijani - 25088 , Byelorussian - 20518, Khanty** - 17128 , Chuvash - 15 261 , Mansi $* *$ - 9894 , and Nenets -1290

$\wedge \wedge$ - In addition, Yamalo-Nenetskii Autonomous Okrug is home to the following nationalities (over 5000 people): Byelorussian -8989, Khanty -8760, Azerbaijani -8353 , Bashkir -7932, Komi -6177 , Moldovan -5400

$\wedge \wedge \wedge$ - In addition, Tyumen' with the AOs is home to the following nationalities (over 10000 people): Azerbaijani - 42 359, Byelorussian - 35996 , Chuvash - 30 205, Nenets - 27 965, German 27 196, Khanty - 26 694, Kazakh - 18639 , Moldovan - 17 938, Kymyk - 12 343, Mariitsy - 11 023, Lezgin - 10630 , Chechen - 10623 , Mansi - 10561 , and Komi - 10555

The threshold for other nationalities listed in footnotes is different for Perm' and Tyumen' Regions after merger and for Khanty-Mansiiskii and Yamalo-Nenetskii Autonomous Okrug because the latter two include small ethnic groups indigenous to these particular area only. For Perm', I list groups over 10000 people, because I consider their numbers are close to fourth largest ethnicity that I list in the table. Additional figures emphasize the historically diverse ethnic composition of the studied regions. 
Table 3-A. Proportion of Ethnic Russians and Other Large Ethnic Groups in Studied Regions

\begin{tabular}{|c|c|c|c|c|c|c|c|c|c|}
\hline \multirow[b]{2}{*}{ Region } & \multirow{2}{*}{$\begin{array}{c}\text { Region } \\
\text { Population as } \\
\text { Share in } \\
\text { Russia's } \\
\text { population, \% } \\
\end{array}$} & \multirow{2}{*}{$\begin{array}{c}\text { Population of } \\
\text { Region before } \\
\text { Merger, (Pop. of } \\
\text { Merged } \\
\text { Region=100\%), \% } \\
\end{array}$} & \multirow{2}{*}{$\begin{array}{l}\text { Population } \\
\text { Increase for } \\
\text { Merged Region } \\
\text { (Oblast' pop. } \\
=100 \% \text { ) } \\
\end{array}$} & \multirow{2}{*}{$\begin{array}{l}\text { \% of Ethnic } \\
\text { Russians in } \\
\text { total region's } \\
\text { population }\end{array}$} & \multicolumn{3}{|c|}{$\begin{array}{c}\text { Proportion of Ethnicities in Region's } \\
\text { Population, } \%\end{array}$} & \multirow[b]{2}{*}{$\begin{array}{c}\text { Fourth } \\
\text { Largest } \\
\text { Ethnicity }\end{array}$} & \multirow[b]{2}{*}{$\begin{array}{l}\text { All Other } \\
\text { Ethnicities }\end{array}$} \\
\hline & & & & & $\begin{array}{l}\text { Largest } \\
\text { Ethnicity }\end{array}$ & $\begin{array}{l}\text { Second } \\
\text { Largest } \\
\text { Ethnicity } \\
\end{array}$ & $\begin{array}{c}\text { Third } \\
\text { Largest } \\
\text { Ethnicity } \\
\end{array}$ & & \\
\hline Perm' Region & 1,85 & 95 & 100 & 87,6 & 87,6 & $\begin{array}{r}5 \\
\text { (Tatar) } \\
\end{array}$ & $\begin{array}{r}1,6 \\
\text { (Bashkir) } \\
\end{array}$ & $\begin{array}{r}0,97 \\
\text { (Udmurt) } \\
\end{array}$ & 4,9 \\
\hline Komi-Permyatskii AD & 0,09 & 4,8 & 5 & 38 & $\begin{array}{r}59 \\
\text { (Komi) }\end{array}$ & 38 & $\begin{array}{r}0,8 \\
\text { (Tatar) } \\
\end{array}$ & $\begin{array}{r}0,7 \\
\text { (Ukrainian) } \\
\end{array}$ & 1,5 \\
\hline $\begin{array}{r}\text { Perm' and AO after } \\
\text { Merger } \\
\text { (Permskii Krai) }\end{array}$ & 1,9 & 100 & 105 & 85 & 85 & $\begin{array}{r}4,9 \\
\text { (Tatar) }\end{array}$ & $\begin{array}{r}3,7 \\
\text { (Komi- } \\
\text { Permyak) } \\
\end{array}$ & $\begin{array}{r}1,4 \\
\text { (Bashkir) }\end{array}$ & 4,9 \\
\hline Tyumen' Region & 0,9 & 40,6 & 100 & 82 & 82 & $\begin{array}{r}8 \\
\text { (Tatar) }\end{array}$ & $\begin{array}{r}1,7 \\
\text { (Ukrainian) }\end{array}$ & $\begin{array}{r}1,5 \\
\text { (German) }\end{array}$ & 6,7 \\
\hline Khanty-Mansiiskii $\mathrm{AO}^{\wedge}$ & 0.987 & 43,9 & 108 & 66 & 66 & $\begin{array}{r}8,7 \\
\text { (Ukrainian) } \\
\end{array}$ & $\begin{array}{r}7,5 \\
\text { (Tatar) } \\
\end{array}$ & $\begin{array}{r}2,5 \\
\text { (Bashkir) } \\
\end{array}$ & 15,3 \\
\hline $\begin{array}{r}\text { Yamalo-Nenetskii } \\
\mathrm{AO}^{\wedge \wedge}\end{array}$ & 0,35 & 15,5 & 38 & 58,8 & 58,8 & $\begin{array}{r}13 \\
\text { (Ukrainian) } \\
\end{array}$ & $\begin{array}{r}5,5 \\
\text { (Tatar) } \\
\end{array}$ & $\begin{array}{r}5,2 \\
\text { (Nenets) } \\
\end{array}$ & 17,2 \\
\hline $\begin{array}{l}\text { Tyumen' and AOs } \\
\text { after Merger } \wedge \wedge \wedge\end{array}$ & 2,2 & 100 & 246 & 71,6 & 71,6 & $\begin{array}{r}7,4 \\
\text { (Tatars) } \\
\end{array}$ & $\begin{array}{r}6,47 \\
\text { (Ukrainian) } \\
\end{array}$ & $\begin{array}{r}1,4 \\
\text { (Bashkir) } \\
\end{array}$ & 13 \\
\hline Irkutsk Region & 1,685 & 94,8 & 100 & 91,8 & 91,8 & $\begin{array}{r}2,1 \\
\text { (Ukrainian) } \\
\end{array}$ & $\begin{array}{r}1,1 \\
\text { (Tatar) } \\
\end{array}$ & $\begin{array}{r}1,1 \\
\text { (Byruat) } \\
\end{array}$ & 3,8 \\
\hline Ust'-Ordynskii AO & 0,09 & 5,2 & 5,5 & 54,4 & 54,5 & $\begin{array}{r}39,6 \\
\text { (Byruat) } \\
\end{array}$ & $\begin{array}{r}3,03 \\
\text { (Tatar) } \\
\end{array}$ & $\begin{array}{r}0,96 \\
\text { (Ukrainian) } \\
\end{array}$ & 1,9 \\
\hline $\begin{array}{r}\text { Irkutsk and } \begin{array}{r}\mathrm{AO} \text { after } \\
\text { Merger }\end{array} \\
\end{array}$ & 1,78 & 100 & 105,5 & 89,9 & 89,9 & $\begin{array}{r}3,1 \\
\text { (Byruat) }\end{array}$ & $\begin{array}{r}2,08 \\
\text { (Ukrainian) } \\
\end{array}$ & $\begin{array}{r}1,2 \\
\text { (Tatar) } \\
\end{array}$ & 3,7 \\
\hline $\begin{array}{l}\text { Other Regions } \\
\end{array}$ & & & & & & & & & \\
\hline Republic of Tatarstan & 2,6 & -- & -- & 39,5 & $\begin{array}{r}52,9 \\
\text { (Tatar) } \\
\end{array}$ & $\begin{array}{r}39,5 \\
\text { (Russian) } \\
\end{array}$ & $\begin{array}{r}3,3 \\
\text { (Chuvash) } \\
\end{array}$ & $\begin{array}{r}0,6 \\
\text { (Udmurt) } \\
\end{array}$ & 3,6 \\
\hline Republic of Chechnya & 0,8 & -- & -- & 3,68 & $\begin{array}{r}93,47 \\
\text { (Chechen) }\end{array}$ & 3,68 & $\begin{array}{r}0,8 \\
\text { (Kymyk) }\end{array}$ & $\begin{array}{r}0,37 \\
\text { (Avartsy) } \\
\end{array}$ & 5,3 \\
\hline City of Moscow & 7,2 & -- & -- & 84,8 & 84,8 & $\begin{array}{r}2,4 \\
\text { (Ukrainian) } \\
\end{array}$ & $\begin{array}{r}1,6 \\
\text { (Tatar) } \\
\end{array}$ & $\begin{array}{r}1,2 \\
\text { (Armenian) } \\
\end{array}$ & 9,9 \\
\hline
\end{tabular}

Source: All-Russia Census Data, 2002 Online at GosKomStat, http//www.perepis2002.ru/ct/doc/ALL 00 01 doc Russia's total population (100\%) is 145166 . For statistics on small indigenous groups of Russia's North, Siberia, and the Far East and their population distribution in Russian regions, see

http://www.raipon.org/russian site/people/people perepis 2002 rus.htm Term Small indigenous groups includes Nenets, Khanty, and Mansi. It does not include Komi-Permyaks and Buriats, because their total number exceeds 50000 
Table 4. Representation in Legislature in Relation to Landmass and Population of Regions *

\begin{tabular}{|c|c|c|c|c|c|c|c|}
\hline \multirow[t]{2}{*}{ Region } & \multirow[t]{2}{*}{$\begin{array}{l}\text { Region's Area, } \\
\mathrm{km}^{2}\end{array}$} & \multirow{2}{*}{$\begin{array}{l}\text { Total Population, } \\
2002 \text { Census }\end{array}$} & \multirow{2}{*}{$\begin{array}{c}\text { Number of } \\
\text { Representatives in } \\
\text { Regional Legislature }\end{array}$} & \multirow{2}{*}{$\begin{array}{c}\text { Number of Citizens per } 1 \\
\text { representative in Regional } \\
\text { Legislature }\end{array}$} & \multirow[t]{2}{*}{$\begin{array}{c}\text { Number of } \mathrm{km}^{2} \text { per } 1 \\
\text { Representative }\end{array}$} & \multicolumn{2}{|c|}{$\begin{array}{c}\text { Number of Representatives in the Federal } \\
\text { Assembly of Russia** }\end{array}$} \\
\hline & & & & & & $\begin{array}{l}\text { Lower House } \\
\text { (Duma) }\end{array}$ & $\begin{array}{c}\text { Upper House } \\
\text { (Federation Council) }\end{array}$ \\
\hline Perm Oblast' & 160237 & 2683345 & 40 & 67084 & 4006 & 3 & 2 \\
\hline Komi-Permyatskii AO & 32900 & 136076 & 15 & 9072 & 2193 & 1 & 2 \\
\hline $\begin{array}{l}\text { Perm' and AO after } \\
\text { Merger (Permskii } \\
\text { Krai) }\end{array}$ & 193137 & 2819421 & $5^{* * *}$ & 51262 & 3512 & 4 & 4 \\
\hline Tyumen' Oblast' & 161800 & 1325018 & 25 & 53001 & 6472 & 2 & 2 \\
\hline Khanty-Mansiiskii $\mathbf{A O}$ & 523800 & 1432817 & 25 & 57313 & 20952 & 3 & 2 \\
\hline Yamalo-Nenetskii AO & 750600 & 507006 & 25 & 20280 & 30024 & 1 & 2 \\
\hline $\begin{array}{l}\text { Tyumen' and AOs } \\
\text { after Merger }\end{array}$ & 1436200 & 3264841 & 75 & 43531 & 19149 & 6 & 6 \\
\hline Irkutsk Oblast' & 767900 & 2446378 & 45 & 54364 & 17065 & 3 & 2 \\
\hline & 22400 & 135327 & 15 & 9022 & 1493 & 1 & 2 \\
\hline $\begin{array}{l}\text { Irkutsk and } \mathrm{AO} \text { after: } \\
\text { Merger }\end{array}$ & 790300 & 2581705 & 60 & 43028 & 13172 & 4 & 4 \\
\hline
\end{tabular}

Source: websites of regional legislatures. Available through http//www.gov.ru/main/regions/regioni-44.html

Area of Russian regions available online at http:/www.wgeo.ru/russia/table.shtml?id=22

Other sources of information on Russian regions are available online at http//www.kommersant.com/tree.asp? rubric $=5$ and http:/www.russiatrek.com/index shtml

* - Note that figures in table are relative estimates because, according to Table X-Mergers of Regions as Mergers of Capital Cities, more than two thirds of population in the studied regions (except Ust'-Ordynskii AD) is urban.

** - Figures for merged regions are sums of representatives in respective regions that are proposed for merger. It is likely that the total numbers of representatives would be smaller. For example, for Tyumen' and AOs after merger they would be not 6, but rather 2 to 4 .

*** - The law on Elections of Representatives in the legislature (Zakonodatel'noe Sobranie) of Permskii Krai sets the number at 60 . However, it is still being disputed. The current proposal from Perm' and KPAO increases it to 80 
Table 5. Mergers of Regions as Mergers of Regional Capital Cities *

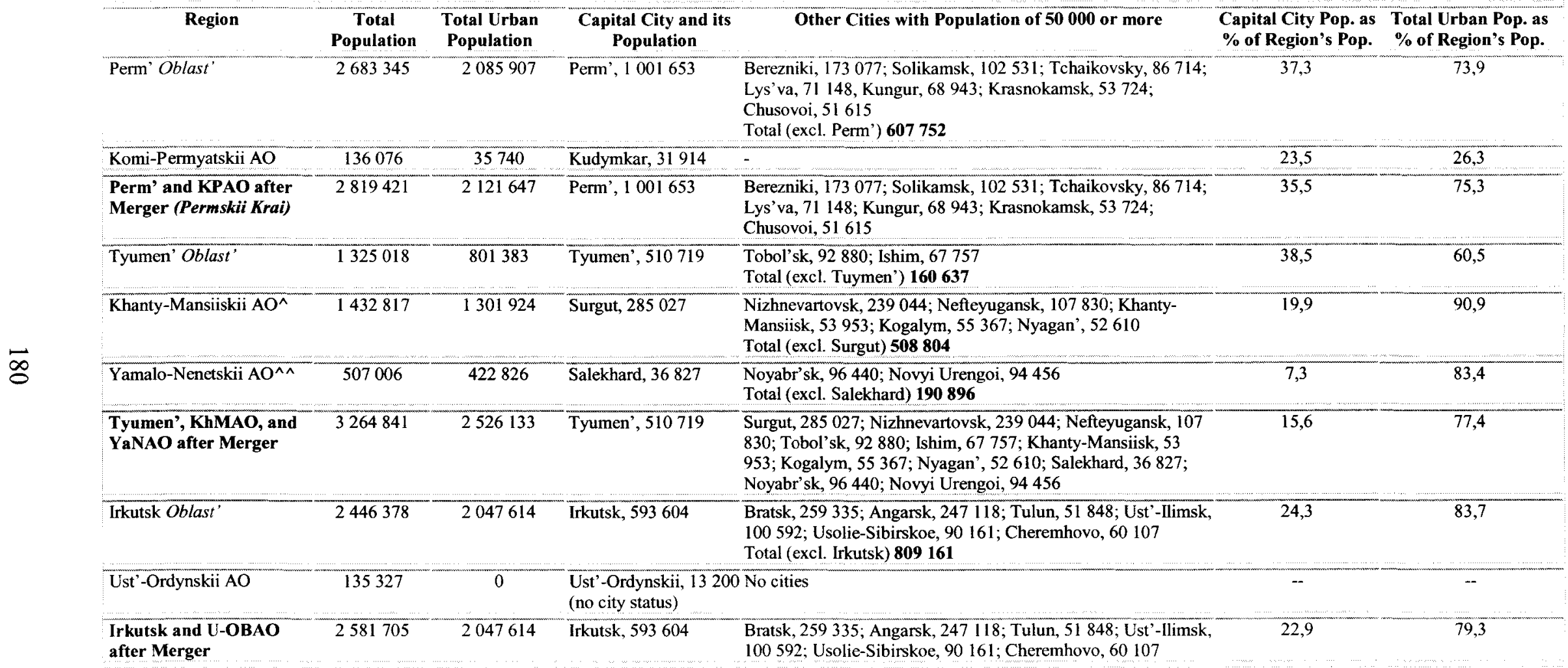

Source: Census 2002, GosKomStat data, htp:/www perepis2002.ru/ct/doc/ALL_00 01 doc

* - This pattern can also be inferred through calculation of urban and rural population density and their ratio 
Table 6. Major Enterprises with Significant Presence in the Region, 2003 and Share of Revenues from Extractive Industries in Consolidated Budgets

\begin{tabular}{|c|c|c|c|c|c|}
\hline Region & $\begin{array}{l}\text { Major Enterprises with Significant } \\
\text { Presence in the Region (excluding oil } \\
\text { production companies), } 2003^{*}\end{array}$ & $\begin{array}{l}\text { Major Oil Production Companies in } \\
\text { Region, } 2003\end{array}$ & $\begin{array}{c}\text { Oil Production, as Share } \\
\text { in Total Russia's Oil } \\
\text { Production, mt and \% } \\
* *\end{array}$ & $\begin{array}{c}\text { Share of Budgetary } \\
\text { Earnings Originating } \\
\text { in Extractive } \\
\text { Industries }+\end{array}$ & $\begin{array}{c}\text { Region's } \\
\text { Creditworthines } \\
\text { s Rating, } \\
2003^{* * *} \\
\end{array}$ \\
\hline Perm' Oblast' & $\begin{array}{l}\text { Uralsvyazinform }(24) \dagger \text {, Uralkalii (58), } \\
\text { Silvinit (71) }\end{array}$ & LUKoil & $10107(2,2 \%)$ & $\begin{array}{l}6,3 \text { (including the } \\
\mathrm{AO} \text { ) }\end{array}$ & 9 \\
\hline Komi-Permyatskii AO & -- & -- & 0 & 2,7 & 79 \\
\hline $\begin{array}{l}\text { Perm' Oblast' and KPAO } \\
\text { (Permskii Krai) }\end{array}$ & & LUKoil & $10107(2,2 \%)$ & 6,3 & $\begin{array}{l}\text { Merger likely to } \\
\text { decrease rating }\end{array}$ \\
\hline Tyumen' Oblast' & Airline Utair (94) & $\begin{array}{l}\text { Surgutneftegaz, Var'eganneftegaz, } \\
\text { RITEK, TNK-BP }\end{array}$ & $1348(0,3 \%)$ & $\begin{array}{l}26,1 \text { (including the } \\
\mathrm{AOs} \text { ) }\end{array}$ & 4 \\
\hline Khanty-Mansiiskii AO & -- & $\begin{array}{l}\text { YUKOS, Surgutneftegaz, } \\
\text { Gazprom, TNK-BP }\end{array}$ & $255766(55,8 \%)$ & 19,8 & 3 \\
\hline Yamalo-Nenetskii AO & -- & $\begin{array}{l}\text { Sibneft, Gazprom, TNK-BP, } \\
\text { Rosneft (Purneftegaz) }\end{array}$ & $52957(11,6 \%)$ & 31,9 & 5 \\
\hline $\begin{array}{l}\text { Tyumen' Oblast', KhMAO, } \\
\text { and YaNAO }\end{array}$ & & $\begin{array}{l}\text { Surgutneftegaz, Var'eganneftegaz, } \\
\text { RITEK, TNK-BP, YUKOS (with } \\
\text { Yuganskneftegaz), Sibneft, } \\
\text { Gazprom, Rosneft }\end{array}$ & $310070(67,7 \%)$ & 26,1 & $\begin{array}{l}\text { Merger likely to } \\
\text { reinforce the } \\
\text { top rating }\end{array}$ \\
\hline Irkutsk Oblast' & $\begin{array}{l}\text { Irkutskenergo (37), Bratsk Aluminum } \\
\text { Plant (67) }\end{array}$ & $\begin{array}{l}\text { Rusia Petroleum, TNK-BP, } \\
\text { Gazprom }\end{array}$ & $76(0,02 \%)$ & $\begin{array}{l}3,3 \text { (including the } \\
\mathrm{AO} \text { ) }\end{array}$ & 40 \\
\hline Ust'-Ordynskii AO & -- & -- & 0 & 1,4 & 82 \\
\hline $\begin{array}{l}\text { Irkutsk Oblast' and U- } \\
\text { OBAO }\end{array}$ & & $\begin{array}{l}\text { Rusia Petroleum, TNK-BP, } \\
\text { Gazprom }\end{array}$ & $76(0,02 \%)$ & $\mathbf{3 , 3}$ & $\begin{array}{l}\text { Merger likely to } \\
\text { decrease rating }\end{array}$ \\
\hline Republic of Tatarstan & $\begin{array}{l}\text { Tatenergo (33), Nizhnekamskneftekhim } \\
\text { (40), KAMAZ (47), Nizhnekamskshina } \\
\text { (66), Kazanorgsintez (74) }\end{array}$ & Tatneft (11) & $29944(6,5 \%)$ & 15,3 & 13 \\
\hline Republic of Chechnya & -- & Rosneft (primarily Grozneftegaz) & $1583(0,4 \%)$ & no data & Below 87 \\
\hline City of Moscow & $\begin{array}{l}\text { TVEL (13), Rostelecom (19), Aeroflot } \\
\text { (29), MGTS (43), Moscow Oil Refinery } \\
\text { (83), Mikoyanovskii Meat Plant (92) }\end{array}$ & -- & 0 & 0,2 & 1 \\
\hline
\end{tabular}

*- Top 100 Russian Enterprises, AK\&M Rating Center, (2003) http//www.akm.ru/rus/rcirpinver 040913 tab2.stm Number in parenthesis represents the company's rating in the top 100. ** Total Production of oil (including gas condensate) for Russia in 2004=458 069 metric tons (mt). Based on calculations by Clifford G. Gaddy, Brookings Institution (total error within 0,5 $\mathrm{mt}$ ). Of that, according to GosKomStat, exports amounted to $257,4 \mathrm{mt}$ or $56,1 \%$.

*** - Integrated Level of Relative Creditworthiness of the Subjects of the RF, AK\&M Rating Center, http:/www.akm.ru/rus/rc/roks 040527.stm

$\dagger$ - Company operates in the greater Ural region; it is headquartered in Perm' since 2004

+ - Russia's average Regional Share $=6,5$. Structure of Incomes of Consolidated Budgets of the Subjects of the Russian Federation in 2001 (Struktura Dohodov Konsolidirovannykh Budjetov Sub'ektov Rossiiskoi Federatsii v 2001 Godu), Statistical Digest "Finansy Rossii," GosKomStat Rossii, Moscow, 2002, in section “State Finances", at p. 45 


\section{CURRICULUM VITAE}

Igor' Yurievich Danchenko

\section{CONTACT INFORMATION}

E-mail: igordanchenko@hotmail.com noemptiness@hotmail.com

\section{EDUCATION}

University of Louisville, Louisville, $\mathrm{KY}$

Department of Political Science, 2005, M.A.

Thesis: The Process of the Enlargement of Russian Regions: Economic Balancing or Landmark of "Kremlinization"?

Perm' State University, Perm', Russia

Major in Civil and International Law, 2000, B.A.

English-Specialized School \# 7, Perm', Russia, 1996

Slidell High School, New Orleans, LA, 1995

\section{PROFESSIONAL EXPERIENCE}

\section{Lawyer, Translator}

"Complex Systems" Scientific Technical Center, LLC; Chelyabinsk, Russia (08/200207/2003)

Organized and maintained contractual database, wrote purchase and sale contracts, and performed other legal duties for a company active in field of heat power plant operation software programs for Russian energy companies JSC Tyumenenergo, Chelyabenergo, Permenergo.

\section{Lawyer, Logistics Engineer, Production Supervisor}

“Khashin Trading House”, LLC; Perm', Russia (10/2002-05/2003)

Wrote land sales-purchase contracts, international sales contracts with EU, and Middle Eastern States, and supervised and provided logistical services to a saw mill operation complex for a company specializing in timber sales-purchase and processing.

\section{Lawyer, Translator}

"Yapitek Construction and Troika Trade \& Logistics" JV; Perm', Russia, Istanbul, Turkey (05-08/2002) 
Wrote contracts, conducted negotiations, and concluded agreements for construction of housing complexes between Yapitek \& Troika, JV and Perm' City Administration.

- Estimated cost and conducted project feasibility analysis

- Collected and analyzed information on Perm' housing market, conditions of facilities and utilities networks

- Compiled bilingual reports

- Successfully negotiated financing of the project with banks Sobinbank and Sberbank

\section{Lawyer for International Issues, Translator, Official Representative in Iran}

“Uralsibspetsstroy," Construction Industrial Concern; Perm', Russia (10/199905/2002)

Translated Company's legal documents, wrote bilingual construction, service, and salespurchase contracts, carried out legal duties in establishing a joint-venture construction company between Uralsibspetsstroy and branches of the Iranian Ministry of Construction, Ministry of Mining and Ministry of Petroleum. Served as representative in Iran between July 2000 and May 2001, where facilitated contracts and projects for strip mining in Sungun Copper Quarry in Ahar (NW Iran), construction of TehranShomal Freeway (Caspian Sea), construction of pipe manufacturing plant for Assaluyeh-Aghajari gas pipeline (Persian Gulf), housing construction in Evin (Tehran) and in Mashad and Tabriz (NW and NE Iran).

In Perm', Russia office, conducted business correspondence with foreign partners, preformed various PR and legal work, and worked on establishing a Russian-Turkish alkaline battery plant Saglam $J V$.

\section{Contract Administrator}

“Permtex” Oil Joint Venture LLC; Perm', Russia (05/1998 - 03/1999)

Wrote contracts (survey, service, sales-purchase, supply, other) in Russian and English languages, organized and conducted bidding procedures, amended, prolonged, cancelled contracts, created and maintained contractual database, interacted with company's departments to assign contracts to employees in charge of execution.

- Initiated and implemented a new procedure of concordance of contracts within company

- Implemented a new bidding procedure for contractors

- Created a contract database for easy access to and control over contractual information

- Organized contract department within the financial department

\section{Logistics Engineer}

“Permtex" Oil Joint Venture LLC; Perm', Russia (07/1997 - 04/1998)

Found suppliers of materials, equipment for oil production and conducted contractual negotiations, maintained databases of purchased materials and crude oil sales and pipeline shipment schedules. 
- Integrated data on purchased materials: developed and sorted data for overall control over company's purchasing process, and optimized purchasing procedure to cut red tape and to create control over and transparency of purchasing and storage processes

- Sold excess pipes to reduce storage costs and conducted market research on pipe manufacturers in Russia, CIS, and Eastern Europe to lower JV's expenses on casing and compressor pipes

\section{OTHER EXPERIENCE}

\section{Open World Russian Leadership Program, U.S. Library of Congress}

Translator/interpreter, facilitator for Russian Delegations in:

New York, NY, Houston, College Station, TX (08-09/1999); Washington, DC, Louisville, KY, Chicago, IL (11-12/2001); Washington, DC, Sacramento, San Francisco, CA (04-05/2002); Washington, DC, Asheville, NC, Dearborn, MI (1011/2003); Louisville, KY, USA (06, 09-11/2004)

Perm' Motovilikha District Police Department, Perm', Russia Criminal Investigator, Assistant Investigator for a variety of cases (06-07/1998, 0607/1999)

City Conference on Civil Contractual Law, Perm', Russia Participant (07/1998, 07/1999)

US Department of State Russian Elections Observation Mission, Perm', Russia Translator, assistant (06-07/1997, 06-07/1998)

Kentucky Country Day High School, Louisville, KY

Student exchange program participant (4-5/1994)

Downside School, Somerset, England

Student exchange program participant (10-11/1993)

\section{HONORS, AWARDS, AND ORGANIZATIONS}

- Political Science Department, University of Louisville, Louisville, KY, Graduate Teaching Assistantship, (8/2003-6/2005)

- Open World Russian Leadership Program of the Library of Congress, Washington, DC, Certificate of achievement, (11/2001, 05/2002)

- British and American Literary Conference, Perm', $1^{\text {st }}$ prize for research on T. S. Eliot's Wasteland, (03/1996)

- Poetry Publications (2), (2000, 2001)

- Freedom Support Act/Bradley Program: High school exchange student in New Orleans, LA; Fall, Winter, and Spring Honor Rolls, graduation with honors (07/1994$06 / 1995)$ 
- American Close-Up Foundation Program, Washington, DC, Participant, (11/1994)

- Honorary Citizen of Louisville, KY (04/1994)

- Geography Olympiad of Perm' Region, $1^{\text {st }}$ prize, diploma, (01/1993)

\section{PROFESSIONAL INTERESTS}

- Russian natural resources and energy industry, its political and economic aspects; Russian oil policy and its domestic and international implications; Russian-US energy cooperation; relations between OPEC and non-OPEC states;

- Russian politics, federal-regional relations in Russia and symmetry of Russian federalism, Russian-Former Soviet Union relations, development of civil society in Russia;

- Migration in Russia and CIS;

- Other areas of interest include former Yugoslavia and the Middle East, particularly Iran.

\section{LANGUAGES}

- Native: Russian

- Wholly fluent written/oral: English

- Beginner level: Persian, Spanish

\section{REFERENCES}

Furnished upon request 